WIDER Working Paper 2014/162

\title{
Ethnic heterogeneity and public goods provision in Zambia
}

Further evidence of a subnational 'diversity dividend'

Rachel M. Gisselquist, ${ }^{1}$ Stefan Leiderer, ${ }^{2}$ and Miguel NiñoZarazúa $^{1}$

December 2014 
Abstract: The hypothesis that ethnic diversity has a negative impact on public goods provision is widely accepted. Notably, most work on this issue fails to distinguish adequately between national versus subnational governance. We find that subnational empirical evidence in particular is inconclusive, and speak to this gap with new analysis at the Zambian district level. Results lend strong support to an emerging body of work challenging the 'diversity debit' hypothesis: we find no clear evidence of a negative impact but instead a robust positive association with key welfare outcomes. Contra the conventional wisdom, future work should explore mechanisms underlying the 'diversity dividend' now suggested in multiple subnational analyses.

Keywords: ethnic diversity, government performance, education, health, Zambia JEL classification: D71, H41, H72, H75, I18, I28

All sources are: Authors' analyses based on data and methods as described in the text.

${ }^{1}$ UNU-WIDER; 2Deutsches Institut für Entwicklungspolitik (DIE); corresponding author: rachel@wider.unu.edu

This study has been prepared within the UNU-WIDER project 'Disadvantaged Groups and Social Mobility' as part of a series of studies on 'The Politics of Group-Based Inequalities: Measurement, Implications, and Possibilities for Change', led by Rachel Gisselquist.

Copyright (C) UNU-WIDER 2014

ISSN 1798-7237 ISBN 978-92-9230-883-4

Typescript prepared by Lisa Winkler at UNU-WIDER.

UNU-WIDER gratefully acknowledges the financial contributions to the research programme from the governments of Denmark, Finland, Sweden, and the United Kingdom.

The World Institute for Development Economics Research (WIDER) was established by the United Nations University (UNU) as its first research and training centre and started work in Helsinki, Finland in 1985. The Institute undertakes applied research and policy analysis on structural changes affecting the developing and transitional economies, provides a forum for the advocacy of policies leading to robust, equitable and environmentally sustainable growth, and promotes capacity strengthening and training in the field of economic and social policy-making. Work is carried out by staff researchers and visiting scholars in Helsinki and through networks of collaborating scholars and institutions around the world.

UNU-WIDER, Katajanokanlaituri 6 B, 00160 Helsinki, Finland, wider.unu.edu

The views expressed in this publication are those of the author(s). Publication does not imply endorsement by the Institute or the United Nations University, nor by the programme/project sponsors, of any of the views expressed. 
The provision of public goods, a key component of government performance, varies substantially across communities. It varies in terms of which goods and services are provided, how they are provided, how well, and in what amounts. This in turn can have broad impacts, directly and indirectly, on economic development (Easterly and Levine 1997). A variety of structural, institutional, and cultural factors, as well as individual agency, may contribute to this variation (see, e.g. Putnam 1993; Gormley 2007; Lijphart 2012). This paper focuses on one key factor that has been emphasized in the literature on developing countries: social divisions, in particular those expressed in ethnic terms. As Banerjee et al. (2005) note, 'the notion that social divisions undermine economic progress, not just in extremis, as in the case of a civil war, but also in more normal times' is 'one of the most powerful hypotheses in political economy.'

The 'diversity debit' hypothesis - that ethnic diversity has a negative impact on social, economic, and political outcomes - has been widely accepted (Gerring et al. 2015). This paper reconsiders it with particular attention to public goods provision, including consideration of government spending and related welfare outcomes. We argue that a key weakness of this work is its failure to distinguish both theoretically and empirically between the factors that influence government performance at national versus subnational levels. If we take this distinction into account, it becomes clear that empirical support at subnational levels in particular is inconclusive, especially in sub-Saharan Africa, where the hypothesis is most strikingly applied. Speaking to key gaps in the literature, the paper offers new empirical evidence using subnational data at district level for Zambia. Including both information on government spending, as well as a wide range of welfare indicators, these data allow for more complete analysis than previous work on the region. As a relatively stable African country in which ethnic divisions have nevertheless been salient in routine forms of politics (Posner 2005; Lindemann 2011a; 2011b), Zambia provides a useful exploratory case.

Contrary to the conventional wisdom, the analysis shows that ethnic diversity is not clearly linked to the under-provision of public goods, and in fact is associated with positive welfare outcomes in key areas. Findings lend strong support to an emerging body of work challenging the diversity debit hypothesis (Singh 2010; Gibson and Hoffman 2013; Gisselquist 2014; Gerring et al. 2015) and highlight the need for more work in future on the mechanisms underlying the 'diversity dividend' now empirically documented in multiple subnational analyses.

The next section of this paper builds on the literature to explore the diversity debit hypothesis with respect to public goods provision, its empirical support, and recent challenges. The paper then turns to the Zambian data, the empirical model used in the analysis, and the results. A final section considers several explanatory hypotheses about the causal processes underlying these results, outlining key areas for future research.

\section{Theory and evidence}

The diversity debit hypothesis has received most attention with reference to sub-Saharan Africa, the most ethnically diverse world region. In a now classic study, Easterly and Levine (1997) find that ethnic heterogeneity is a significant factor in explaining the region's slow growth relative to East Asia, through its effect on poor policy. Ashraf and Galor (2013a; 2013b) argue that genetic composition that evolved over the course of prehistoric migration is behind the hump-shaped effect of Africa's ethnic diversity on economic development. Using compiled data for 'politically 
relevant' ethnic groups, Posner (2004) finds that ethnic heterogeneity is also associated with internal variation in growth across African countries. The diversity debit hypothesis with respect to public goods provision has become so widely accepted that significant work has emphasized that research should no longer examine whether it holds, but instead focus on theorizing and testing of why it holds, i.e. the mechanisms underlying the relationship (Habyarimana et al. 2007).

The literature highlights at least five broad mechanisms underlying a negative relationship between ethnic diversity and public goods provision: The first is driven by variation in ethnic groups' preferences or tastes over what is provided, where, and/or how (Chandra 2001). The classic example is school funding in a community in which groups have different native languages. Because Group A favours instruction in Language A and Group B favours instruction in Language $\mathrm{B}$, community members favour contributing less to the public provision of a school.

A second broad mechanism is driven not by substantive variation in group characteristics or tastes but by preferences vis-à-vis the other group(s) and/or their own group prejudice for short. In this mechanism, ethnic groups contribute less to public goods because they prefer not to mix with members of other ethnic groups, derive negative utility when a public good is shared with members of other ethnic groups or provided to members of other groups, or derive greater utility from the provision or enjoyment of a good with co-ethnics than with non-co-ethnics.

Highlighting both the first and second mechanisms, Alesina et al. (1999) develop the standard preference-based model in which the average individual's utility is $u_{i}=g^{a}\left(1-l_{i}\right)+c$, where $g$ is the public good, $l_{i}$ is the distance between individual $i$ s preferred type of public good and the public good provided, and $c$ is private consumption. Private consumption $(c)$ is equal to exogenous pretax income $(y)$ minus a lump-sum tax ( $t)$ (see also Kimenyi 2006). ${ }^{1}$ The model has three main results: i) assuming a majoritarian election system, the type of public good chosen will be the one preferred by the median voter; ii) in equilibrium, the median distance from the median voter's ideal type $\left(l_{i}^{m}\right)$, an indicator of the polarization of preferences, will determine the size of the public good, i.e. $g^{*}=\left[a\left(1-l_{i}^{m}\right)\right]^{\frac{1}{1-a}}$, and iii) in equilibrium, the size of the public good will be decreasing in $l_{i}^{m}$ as polarization increases.

A third key mechanism, social capital, focuses on public goods provision as a collective action problem (Khwaja 2009). Solving collective action problems may be more difficult in more heterogeneous communities as compared to more homogenous communities because the latter tend to have stronger social capital (Putnam 2007). Social capital is 'a set of institutionalized expectations that other social actors will reciprocate co-operative overtures' which in turn 'generates co-operation by making otherwise uncooperative actors willing to undertake those overtures in the first place' (Boix and Posner 1998). Trust may be higher among members of an ethnic group than across groups, so individuals may expect co-ethnics to be more likely to cooperate (see Bahry et al. 2005). Likewise, social sanctions may be stronger within a group than across groups (see Miguel and Gugerty 2005).

Collective action may also simply be easier in more homogeneous communities because of shared language and culture, geographic proximity, or stronger within-group personal relationships that

\footnotetext{
${ }^{1}$ The population size is normalized at 1 , so that $g$ represents the per capita and aggregate size of the public good.
} 
facilitate collaboration (Deutsch 1966). Habyarimana et al. (2007) label this fourth set of explanations a 'technology' mechanism.

The first four mechanisms, which have been the focus of the political economy literature on this topic, operate at the level of the voter, citizen, or community member: because of differing tastes, preferences, lack of social capital, or poor 'technology', community members are expected to contribute less or less efficiently to public projects, resulting in a negative relationship between diversity and public goods provision. A fifth key family of mechanisms hinges on how ethnic heterogeneity may influence governing elites, and through this, government performance. Governments in which members come from diverse groups may govern less effectively than more homogenous governments because of the differing tastes, preferences, lack of social capital, or poor technology of their members as a group, which hinder collaboration much in the way that they do for the average citizen. Ethnically-diverse governments, for instance, may be more likely to deadlock in decisions because members' preferences and interests conflict, or they may be unable to pass more difficult legislation requiring stronger cooperation and coalition-building. Individuals within government also may be elected or come to power primarily due to the support of ethnic coalitions, rather than more broadly-based constituencies. Thus, they may favour policies to support their ethnic bases over others, diverting resources in economically inefficient ways (Franck and Rainer 2012).

These five broad mechanisms need not be mutually exclusive. Habyarimana et al. (2007), for instance, find experimental support for both the third and fourth mechanisms at the individual level, while Jackson (2013) posits that preference-based versus collective action-based mechanisms operate for different types of public goods. Furthermore, it is not necessarily the ethno-cultural characteristics of ethnic groups that underlie these mechanisms, with the exception of the second. If ethnic groups tend to be regionally concentrated-for whatever reason-they may have different and conflicting interests over where to locate schools, roads, or health centers, regardless of cultural commonalities, ethnic hatreds, or historical ethnic myths of origin. Likewise, economic inequalities between groups may also drive the relationship, perhaps through impact on betweengroup differences in preferences, prejudice, and social capital (Alesina and La Ferrara 2000; Baldwin and Huber 2010; Waring 2012). The key point for our analysis is that all five mechanisms predict a negative relationship between ethnic heterogeneity and public goods provision.

This relationship further is expected to hold regardless of the level at which analysis takes place. While this is not explicitly stated in the mechanisms above, the hypothesis is routinely applied to explain variation in government performance both cross-nationally and subnationally (in villages, municipalities, cities), and empirical analyses at the national level are cited as evidence for the hypothesis at the subnational level and vice versa. This is a key lacuna in the literature because we know that national and subnational governments operate differently. For one, different levels of government have different roles and responsibilities, suggesting that analysis of the factors influencing the provision of particular public goods generally is most appropriate at the level of government with most discretion over the respective sectors as particular sectors may be centralized to different degrees. Funding may also come both from national and multiple subnational levels and the relative contribution of each may vary both across countries and within them. In the USA, for instance, federal, state, and local governments all provide funding for education and the relative contribution of the federal level systematically varies state to state. Thus, in exploring budgetary outcomes at subnational levels, intergovernmental transfers add a level of complexity to the simple prediction and mechanisms outlined above.

In short, for countries in which funding for public goods like health and education is highly centralized — as in much of sub-Saharan Africa-we might amend the simple prediction of the 
diversity debit hypothesis for subnational analyses as follows: First, we distinguish between budgetary outcomes and other measures of government performance, including related welfare outcomes. In the centralized case, local governments and constituencies have little direct influence on budgets according to the mechanisms outlined above as they neither contribute a large share of revenues (taxes) nor directly decide budgetary allocations or policies. At the level of implementation, however, subnational governments and constituencies do have direct influence on how budgets are spent and policies carried out. Community characteristics (including diversity) may also directly affect related welfare outcomes by influencing how communities use and interact with government services. For instance, diversity may have an impact on preferences or social capital which in turn may influence parents' decisions to enroll their children in school, and thus educational enrollment rates.

\subsection{Empirical studies}

The preceding discussion suggests that in considering the empirical bases upon which the conventional wisdom rests, it is useful to consider empirical studies at the national and subnational levels separately.

Broadly speaking, empirical support for the diversity debit hypothesis appears relatively robust at the national level. ${ }^{2}$ Easterly and Levine (1997) show a relationship between ethnic heterogeneity and low schooling and insufficient infrastructure, as well as other policy-related outcomes such as political instability, underdeveloped financial systems, distorted foreign exchange markets, and high government deficits. Baldwin and Huber (2010) find support in an analysis of 46 countries considering an aggregate measure of public goods provision based on ten variables related to education, health, sanitation, infrastructure, and the regulatory framework for private sector activity. Jackson (2013) finds support for the diversity debit hypothesis in the areas of education, drinking water, and electricity across 18 African countries, while Gerring et al. (2015) do so across 36 developing countries in terms of human development outcomes, including child mortality, fertility, education, and wealth.

At the subnational level, however, empirical support for the diversity debit hypothesis is less clear. The most cited study at the subnational level is Alesina et al. (1999), which uses US census data (1990) and budget information from all cities, metropolitan areas, and urban counties with populations of at least 25,000 . This analysis considers a range of dependent variables on spending, showing that ethnic fractionalization, measured in racial terms, is negatively associated in a statistically significant manner with the share of public spending on roads, education, welfare, and sewage and trash pickup. Subsequent work has highlighted several weaknesses with these findings, however. First, as the study itself shows, some results are not consistent with the under-provision of public goods, e.g. spending on health. ${ }^{3}$ Second, the results appear less robust when controls for state level effects are included, which seems wise within the US context, as fiscal responsibilities and regulations differ across states, as does ethnic fractionalization (Gisselquist 2014).

\footnotetext{
2 Why this relationship holds however remains open for discussion. Alesina et al.'s (1999) model is widely cited, but it relies on the median voter theorem which is generally formulated on the basis of two party competition under plurality rule - i.e., a different institutional context to many of the countries under analysis. Interpretation is further complicated by the quality of data on public goods provision and government budgets that is available at the crossnational level.

3 There is also a positive relationship with spending on police. This arguably can be reconciled within the model: polarized preferences may also lead to higher levels of social conflict and thus greater demands for policing.
} 
Examination of additional outcomes using the same data further suggests a positive relationship between fractionalization and levels of educational expenditure per child (Gisselquist 2014).

Third, although the article is cited widely in work on non-US settings, to the best of our knowledge no similar findings have been replicated outside of the USA. It is plausible that ethnic relations and local government spending are comparatively unique in the USA in ways that complicate application of these findings elsewhere. ${ }^{4}$ As outlined above, we would also predict a different relationship in countries with more centralized funding of public services than the US More broadly, government processes can be expected to operate differently in relatively high rule of law settings where formal institutions are respected (like the USA), as compared to the neopatrimonial regimes that characterize much of Africa (Bratton and van de Walle 1994). Expectations drawn from formal models of voting, for instance, are arguably problematic in situations where we cannot assume that electoral rules are always followed and that electoral results thus reflect population preferences. Along these lines, von Soest (2007) finds that informal, not formal institutions, are key to understanding state resources and tax collection in Zambia in particular.

A few studies of ethnic fractionalization at the subnational level in Africa have tested a limited range of public goods outcomes, including primary education (funding, quality of facilities, and textbook ownership) and the maintenance of water wells, in non-representative population samples of Kenya and Tanzania (Miguel 2004; Miguel and Gugerty 2005). Miguel (2004) finds evidence that the negative relationship between ethnic divisions and public goods provision holds only where ethnic identity is comparatively stronger than national identity (see also Singh 2010). In an experimental setting, Levine et al. (2014) find that ethnic diversity does have a positive effect on market functioning. They argue that the presence of ethnic diversity disrupts conformity, prevents detrimental herding behaviour and fosters greater scrutiny and more deliberate thinking, which can lead to better outcomes. More recently, Gerring et al. (2015), find a positive relationship between ethnic diversity and human development outcomes at the subnational level (but a negative relationship at the national level), in a sample of 36 developing countries, 24 of which are located in sub-Saharan Africa. Similarly, and particularly relevant for our analysis is the study by Gibson and Hoffman (2013) which finds that ethnic fractionalization is positively correlated with local government expenditure, using budget data for local district councils in Zambia.

In short, and contrary to conventional wisdom, we find that empirical tests of the diversity debit hypothesis remain inconclusive, and further empirical work is in order, especially in neopatrimonial African regimes at the subnational level. While our focus here is on empirical testing of the broad diversity debit prediction with respect to public goods provision and related welfare outcomes, we return in the final section of this paper to possible explanations of our discordant empirical findings.

Gibson and Hoffman (2013)'s findings provide a useful starting point for our analysis. In particular, they speak precisely to the relationship between subnational ethnic diversity and government expenditure excluding central government transfers. The data thus allow the authors to directly test the central prediction above without considering national-subnational interactions, which is useful. However, if our purpose is to consider more broadly the relationship between subnational ethnic diversity and government performance in centralized countries such as Zambia, it is also incomplete.

\footnotetext{
${ }^{4}$ For instance, intergovernmental transfers in the USA may be influenced indirectly by ethnic diversity, thus affecting local spending.
} 
This is because, despite continuing efforts towards decentralization, government expenditure in most sub-Saharan African countries like Zambia remains highly centralized. According to the most recent Public Expenditure and Financial Accountability (PEFA) report, overall spending by local councils accounts for less than 5 per cent of Zambian general government expenditure (Republic of Zambia 2008). Moreover, the share of local government spending that goes to service delivery is also very small in Zambia. In 2007, for instance, local councils spent on average a mere 10 per cent of their expenditure on service delivery, with the remaining budget used for administration and personal emoluments, this despite a 40 per cent target set by the Ministry of Local Government and Housing (Leiderer et al. 2012). Most of Zambia's social sector spending on health and education is therefore channeled through the central government via de-concentrated units at district level (District Health Management Teams-DHMTs, and District Education BoardsDEBs).

Thus, if the diversity debit hypothesis is correct, we would not expect to see a relationship between subnational ethnic diversity and total government expenditure at the district level (including central government transfers), but we would expect to see a relationship between subnational ethnic diversity and measures of implementation and related welfare outcomes, controlling for total expenditure. We explore these key predictions below.

\section{Data}

We use a new purpose-built disaggregated dataset for Zambia covering the period 2004-2009. ${ }^{5}$ To avoid any bias caused by the fact that cities tend to be ethnically more diverse as a result of ruralurban migration patterns, and also have a much stronger resource base, both locally as well as in terms of central government spending, we limit the sample to cover all the 14 municipal and 54 rural districts, while excluding the four cities in the country.

The data come from the following sources: the Census of Population and Housing for 2000 and 2010 for information on ethnicity and language use; the 2006 Living Conditions Monitoring Survey (LCMS) for information on poverty levels and other district characteristics; the Government Financial Report (GFR) for information on budget allocations from the central government to districts; information provided by the Ministry of Health and the Ministry of Education for health and education outcomes.

This new dataset offers important benefits over data used in previous studies of ethnic diversity and public goods provision. First, it allows us to examine the relationship between ethnic diversity and executed government expenditure to the districts and to control for central government expenditure in analysis of other district level governance outcomes. Second, and unlike most of previous studies, the data allow us to examine longer term behaviours in a dynamic setting.

\subsection{Measuring diversity}

In Zambia, both tribal and linguistic cleavages have been salient in politics and governance (Posner 2005; Lindemann 2011a, 2011b). The 2000 Census includes information on individuals' selfreported ethnicity as well as on each person's predominant language of communication. Both variables are coded in the census according to the same 61 local languages, grouped into seven

\footnotetext{
${ }^{5}$ Although we have data on welfare outcomes for the period 2001-2009, the shorter time window of the expenditure data, from 2004-2009, meant that we were able to only cover the period 2004-2009 in our analysis.
} 
main ethno-linguistic groups: Bemba, Tonga, North-Western, Barotse, Nyanja, Mambwe, and Tumbuka; plus an eighth group for 'other', which for the predominant language-use variable includes English (Republic of Zambia 2000). ${ }^{6}$

For the purpose of this paper, we capture ethnic diversity in terms of the index of ethno-linguistic fractionalization (ELF) at the district level using both 'ethnic' and 'language' categories. While the literature offers a number of alternative measures, we use this measure because it is the one used almost exclusively in the work cited above (Gisselquist and McDoom 2014). Fractionalization is calculated as:

$$
E L F_{i}=1-\sum_{g=1}^{n} q_{g i}^{2}
$$

where $q_{i j}$ is the population share of language or ethnic group $g=1 \ldots n$, in district $i$. The obtained ethnic (ELF-E) and linguistic (ELF-L) fractionalization indices are highly but not perfectly correlated, with a correlation coefficient $r=0.85 .^{7}$ In spite of their similarity, it can be argued that each index reflects different aspects of ethno-linguistic diversity. The ELF-E is presumably the more accurate measure of fractionalization in terms of ethnic identity and thus speaks to those mechanisms underlying the diversity debit hypothesis that stress the role of preferences or trust within and across ethnic groups. The ELF-L in contrast assesses social salience of fractionalization in terms of language use for 'day-to-day communication with [...] neighbors, at factory, in office, in market places, etc.' (Republic of Zambia 2000), which is arguably driven at least party by social and economic needs rather than ethnic identity. This measure therefore speaks more to those mechanisms that stress the role of social capital and common 'technology'. As a robustness check, we estimate the models presented in Section 4 with both indices.

\subsection{Measuring public goods provision via government expenditure}

Zambia introduced government-wide activity-based budgeting in 2004 and government financial reports (GFRs) follow a mixed administrative and program classification. This allowed us to extract information on central government expenditure on health and education in each district.

Education expenditure by district is recorded in the GFRs under two different budget lines, namely 'Regional Headquarters' and 'Basic Schools.' Under the former, expenditures administered by each District Education Board (DEB) are recorded, including grants for free basic education and infrastructure development; under the latter, two expenditure items are reported over which the local DEBs formally have no influence: salaries and other emoluments; and grants to basic schools that are transferred from the Ministry of Education to DEB offices from where they are distributed among schools according to an allocation formula based on school characteristics such as enrolment figures, number of classes and a gender parity factor (IOB 2008; World Bank 2008). ${ }^{8}$

\footnotetext{
${ }^{6} \mathrm{It}$ is worth noting that the ethnic groups used in our analysis also approximate the politically salient groups identified by the Ethnic Power Relations dataset version 3.01 Wimmer et al. (2009). Bemba speakers, Tonga-Ila-Lenje, Nyanja speakers (Easterners), Lozi (Barotse), Lunda (NW Province), Luvale (NW Province), and Kaonde.

7 As is to be expected, the average ELF-L (and its standard deviation) is substantially smaller than the ELF-E (see Table 1), as people in ethnically diverse communities will generally use only a limited number of common languages for everyday communication.

8 These grants are used by basic schools to purchase mostly locally procured learning and teaching materials.
} 
For health, all expenditure at district level is recorded under the budget line of the respective District Health Management Team (DHMT).

For the purpose of this study, we extracted seven expenditure categories at district level for the years 2004-2009. For education they include total education expenditure, DEB administered expenditure, basic schools allocations, grants to basic schools, and teachers' salaries. For the health sector we include total health expenditure and expenditure on health service delivery (available only for 2006-2009 and including various sub-items; see Table 1).

In addition to total allocations, in each category, we calculate annual per capita expenditure using (interpolated) district population figures taken from the 2000 and 2010 Census. For the teachers' salaries and grants for basic schools we use the population in the relevant age group of primary school pupils (7 to 13 years) in 2000 to calculate per capita figures. ${ }^{9}$

For each budget item, the GFR reports budget estimates, authorized provisions, actual expenditure, and budget variance. In addition to actual expenditure, we are also able to calculate budget execution rates i.e. the ratio of money expended compared to releases received by the respective spending unit for each expenditure item, which provide a measure of the deconcentrated government units' operational efficiency or absorptive capacity.

\subsection{Measuring government performance via education and health outcomes}

Data on education outcomes is relatively limited, covering the number of pupils in grades 1-7 and grades 1-9 for the period 2004-2009. From this and using census data on population by age group, we were able to construct gross enrollment rates for primary education (grades 1-7) and lower secondary education (grades 8 and 9). In addition, we obtained data on the total number of pupils and teachers (grades 1-12) for 2008; and the number of schools, pupils and teachers in basic education for 2009.

Data on health is more comprehensive, although it covers a shorter time frame (2004-2008). Based on the available data, we calculated 11 health indicators that include: the number of beds in health facilities per 1000 inhabitants; health center staff per capita; hospital outpatient department staff per capita; the maternal mortality rate; the under-five mortality rate; the rate of underweight children under five; under one year olds' immunization rates for tuberculosis, diphtheria-pertussistetanus; polio; and the rate of fully immunized children under one year.

\subsection{District level covariates}

District level covariates that are expected to affect government expenditure and/or welfare outcomes were constructed using information from various sources. As a general measure of the level of deprivation, we calculated district level poverty headcounts using data from the 2006 LCMS. Annual district level population estimates were calculated by interpolating data from the 2000 and 2010 Population Census. Data on the district surface area measured in square kilometers were extracted from the 2000 Population Census to capture the spatial dimension of districts.

A dummy variable was constructed using the 2006 LCMS surveys, to control for possible infrastructure and scale economy effects from rural environments. We also used the routing function of the Google Maps ${ }^{\mathrm{TM}}$ mapping service to construct a variable that measures the distance

\footnotetext{
${ }^{9}$ Population by age-group is only available from the 2000 Census.
} 
by road from each district capital to the national capital Lusaka, as a measure of geographic location and remoteness.

Finally, and in order to control for possible political targeting of social sector spending, we used information on election results in national presidential elections in 2001 and 2006 from the Zambia Electoral Commission to construct a variable that calculates the district share of votes for the ruling party, Movement for Multiparty Democracy, MMD, in the 2001 and 2006 presidential elections, using 2001 values for all years up to 2006 and 2006 values for 2007 and subsequent years (see Table 1).

\section{$4 \quad$ Model specification and econometric methods}

Based on the theoretical discussion presented in Section 2, we proceed to undertake the empirical analysis in two steps. First, we begin in Section 4.1 with a model that tests the diversity debit hypothesis with regard to spending on public goods. The model examines whether ethnic heterogeneity at district level is related to lower allocation of central government expenditure. As above, in centralized countries such as Zambia we predict no relationship based on the mechanisms underlying the diversity debit hypothesis. As a second step, we develop a model in Section 4.2 that tests the diversity debit hypothesis with regard to welfare outcomes. As above, in centralized countries such as Zambia, we predict that the diversity debit mechanisms should be evident here. 
Table 1: Summary statistics for rural and municipal districts, 2004-2009

\begin{tabular}{|c|c|c|c|c|c|c|c|}
\hline Variable & Definition & Data source & $\mathrm{N}$ & Mean & SD & Min & Max \\
\hline \multicolumn{8}{|c|}{ Ethnic fractionalization by district } \\
\hline ELF-E & ELF measure based on main "ethnic" groups as identified in the Census & $\begin{array}{l}\text { Census } \\
2000\end{array}$ & 68 & 0.307 & 0.227 & 0.013 & 0.777 \\
\hline ELF-L & ELF measure based on main "language" groups as identified in the Census & $\begin{array}{l}\text { Census } \\
2000\end{array}$ & 68 & 0.201 & 0.182 & 0.005 & 0.683 \\
\hline \multicolumn{8}{|l|}{ District level covariates } \\
\hline Area & Surface area $\left(\mathrm{km}^{2}\right)$ & $\begin{array}{l}\text { Census } \\
2000\end{array}$ & 68 & 11 & 8 & 1 & 41 \\
\hline Poverty & Poverty headcount in 2006 & LCMS 2006 & 68 & 0.695 & 0.161 & 0.224 & 0.961 \\
\hline Population & Logarithm of population & $\begin{array}{l}\text { Census } \\
2000 / 10\end{array}$ & 408 & 11.694 & 0.554 & 9.975 & 13.003 \\
\hline Distance Lusaka & Distance from the district capital to Lusaka $(\mathrm{km})$ & $\begin{array}{l}\text { Google } \\
\text { Maps }^{T M}\end{array}$ & 68 & 577 & 294 & 45 & 1170 \\
\hline Rural & Dummy variable $=1$ if district is classified as rural (vs. municipal or city) & LCMS 2006 & 68 & 0.794 & 0.405 & 0 & 1 \\
\hline Vote MMD & $\begin{array}{l}\text { Vote share for the ruling party in the most recent presidential election prior to } \\
\text { the year of analysis ( } 2001 \text { for } 2001-2006 \text { and } 2006 \text { for } 2007-2009)\end{array}$ & ECZ & 136 & .418 & .200 & .077 & .884 \\
\hline \multicolumn{8}{|c|}{ Central government district expenditure (in billion kwacha) } \\
\hline Education expenditure & Total central government expenditure for education in each district & GFR & 408 & 10.537 & 6.373 & 0.809 & 47.020 \\
\hline $\begin{array}{l}\text { Education expenditure } \\
\text { p.c. }\end{array}$ & Education expenditure per capita & GFR & 408 & 0.092 & 0.057 & 0.006 & 0.322 \\
\hline DEB expenditure & Total central government expenditure to DEB & GFR & 408 & 0.639 & 1.186 & 0.046 & 16.430 \\
\hline $\begin{array}{l}\text { DEB expenditure per } \\
\text { capita }\end{array}$ & DEB expenditure per capita & GFR & 408 & 0.006 & 0.007 & 0.000 & 0.088 \\
\hline Basic school expenditure & $\begin{array}{l}\text { Total central government expenditure for basic schools (including personal } \\
\text { emoluments and grants) }\end{array}$ & GFR & 408 & 9.989 & 6.315 & 0.457 & 46.662 \\
\hline Basic expenditure p.c. & Basic schools expenditure per capita & GFR & 408 & 0.087 & 0.055 & 0.004 & 0.310 \\
\hline Grants basic schools & expenditure on grants to basic schools & GFR & 406 & 0.875 & 1.105 & 0.000 & 5.675 \\
\hline Grants basic schools p.c. & expenditure on grants to basic schools per capita & GFR & 406 & 0.031 & 0.041 & 0.000 & 0.252 \\
\hline Teachers' salaries & expenditure on teachers' salaries & GFR & 400 & 5.821 & 4.375 & 0.013 & 37.116 \\
\hline Teachers' salaries p.c. & expenditure on teachers' salaries per capita & GFR & 400 & 0.198 & 0.124 & 0.001 & 1.020 \\
\hline Health expenditure & total DHMT team expenditure & GFR & 408 & 4.193 & 4.986 & 0.014 & 33.469 \\
\hline Health expenditure p.c. & total DHMT expenditure per capita & GFR & 408 & 0.030 & 0.034 & 0.000 & 0.450 \\
\hline Health service delivery & $\begin{array}{l}\text { health service delivery expenditure; included items are: epidemic } \\
\text { preparedness, provision of 1st level referral services, roll back malaria, } \\
\text { HIVIAIDS/STIs, tuberculosis, integrated reproductive health, child health, } \\
\text { environmental health, mental health, oral health. }\end{array}$ & GFR & 272 & 1.403 & 0.981 & 0.062 & 7.812 \\
\hline $\begin{array}{l}\text { Health service delivery } \\
\text { p.c. } \\
\text { Budget execution rates }\end{array}$ & health service delivery expenditure per capita & GFR & 272 & 0.011 & 0.005 & 0.001 & 0.041 \\
\hline
\end{tabular}




\begin{tabular}{|c|c|c|c|c|c|c|c|}
\hline Educ. execution & education budget execution rate & GFR & 408 & 0.993 & 0.085 & 0.516 & 1.264 \\
\hline DEB execution & DEB budget execution rate & GFR & 408 & 0.836 & 0.180 & 0.251 & 1.126 \\
\hline Basic schools execution & basic schools budget execution rate & GFR & 408 & 1.005 & 0.107 & 0.378 & 1.392 \\
\hline $\begin{array}{l}\text { Basic school grants } \\
\text { execution }\end{array}$ & grants to basic schools budget execution rate & GFR & 406 & 1.391 & 1.224 & 0.000 & 6.308 \\
\hline $\begin{array}{l}\text { Teachers' salaries } \\
\text { execution }\end{array}$ & teachers' salaries budget execution rate & GFR & 400 & 0.993 & 0.040 & 0.500 & 1.000 \\
\hline Health execution & DHMT budget execution rate & GFR & 408 & 0.670 & 0.293 & 0.010 & 1.302 \\
\hline $\begin{array}{l}\text { Health service execution } \\
\text { Educational outcomes }\end{array}$ & health service delivery budget execution rate & GFR & 272 & 0.813 & 0.242 & 0.098 & 2.137 \\
\hline Prim. school enrolment & primary school enrolment (grades 1-7) & MoE & 408 & 1.234 & 0.247 & 0.577 & 2.047 \\
\hline Low sec. enrolment & lower secondary school enrolment (grades 8 and 9) & MoE & 408 & 0.552 & 0.269 & 0.086 & 1.541 \\
\hline No. schools 2008 & number of schools (all schools) in 2008 & MoE & 68 & 116 & 52 & 21 & 278 \\
\hline No. teachers 2008 & number of teachers (all schools) in 2008 & MoE & 68 & 910 & 526 & 213 & 2799 \\
\hline No. basic schools 2009 & number of basic schools in 2009 & MoE & 68 & 114 & 52 & 18 & 285 \\
\hline TPR 2008 & teacher- pupil ratio (all schools) in 2008 & MoE & 68 & 0.022 & 0.005 & 0.013 & 0.038 \\
\hline $\begin{array}{l}\text { Basic school TPR } 2009 \\
\text { Health outcomes }\end{array}$ & teacher-pupil ratio for basic schools in 2009 & MoE & 68 & 0.019 & 0.005 & 0.009 & 0.035 \\
\hline Total beds & number of beds in health facilities per 1000 population & $\mathrm{MoH}$ & 329 & 2.308 & 1.719 & 0.705 & 26.598 \\
\hline HC staff & health center staff per 10,000 population & $\mathrm{MoH}$ & 329 & 4.208 & 2.128 & 0.687 & 12.305 \\
\hline Hospital OPD staff & hospital outpatient department staff per 10,000 population & $\mathrm{MoH}$ & 255 & 0.704 & 0.611 & 0.000 & 3.836 \\
\hline BCGimmun & under 1 year olds' immunization rate for tuberculosis & $\mathrm{MoH}$ & 329 & 1.223 & 0.225 & 0.432 & 2.442 \\
\hline DPT3immun & $\begin{array}{l}\text { rate of under } 1 \text { year olds with } 3 \text { doses of the combined } \\
\text { diphtheria/pertussis/tetanus vaccine }\end{array}$ & $\mathrm{MoH}$ & 329 & 1.118 & 0.239 & 0.491 & 2.131 \\
\hline OPV3immun & rate of under 1 year olds with 3 doses of oral polio virus vaccine & $\mathrm{MoH}$ & 329 & 1.095 & 0.260 & 0.488 & 2.437 \\
\hline Measles & under 1 year olds' immunization rate for measles & $\mathrm{MoH}$ & 329 & 1.017 & 0.202 & 0.481 & 2.123 \\
\hline FICimmun & rate of fully immunized under 1 year old children & $\mathrm{MoH}$ & 329 & 0.821 & 0.177 & 0.312 & 1.806 \\
\hline Mat. mortality & maternal mortality (maternal deaths per 100000 live births) & $\mathrm{MoH}$ & 320 & 271.86 & 463.92 & 0.000 & 7520.33 \\
\hline U5 mortality & under five mortality (deaths of children under 5 per 1000 live births) & $\mathrm{MoH}$ & 329 & 58.087 & 36.486 & 2.542 & 414.394 \\
\hline Underweight5 & underweight children under the age of 5 per 100 under 5 year olds weighed & $\mathrm{MoH}$ & 329 & 13.856 & 7.426 & 0.945 & 35.857 \\
\hline
\end{tabular}

Source: GFR: Government Financial Reports ('Blue Books'); LCMS: Living Conditions Monitoring Survey; DEB: District Education Board; DHMT: District Health Management Team; ECZ: Electoral Commission of Zambia; MoE: Ministry of Education; MoH: Ministry of Health. 


\subsection{The public goods provision model}

More formally, we derive a model that takes the form:

$$
s_{i t}=\alpha_{i t}+\beta x_{i t}+\lambda f_{i}+\mu_{i}+\zeta_{t}+v_{i t}
$$

where the subscripts $i$ and $t$ denote district and year, respectively; $S_{i t}$ measures various items of government expenditure on education or health; $x_{i t}$ is a vector of district level covariates that are expected to affect the governments allocation decisions, including (i) the logarithm of district population to control for scale effects with respect to central government allocations; (ii) the local poverty headcount index as a measure of deprivation that may capture the existing demands for social services at local level; (iii) the district surface area to capture the spatial dimension of districts that may affect the transaction costs associated with public goods provision; (iv) a binary indicator that identifies rural communities to capture possible infrastructure and scale economy effects; $(\mathrm{v})$ the distance to the national capital Lusaka as a measure for remoteness and access to the center of political power, and vi) the ruling party's vote share in past presidential elections, which controls for the possibility of political targeting of health and education spending. $f_{i}$ is the ethnic or linguistic fractionalization index that measures the effect of ethnic diversity on government expenditure; $\mu_{i}$ denotes unobserved district-specific and time-invariant effects; $\zeta_{t}$ is a vector of time dummies capturing universal time trends, whereas $a, \beta, \lambda$, and $\nu$ are the intercept, the parameter estimates and the idiosyncratic error term, respectively. We estimate the model for each of the expenditure items both for levels of total expenditure as well as in per capita terms. Should the diversity debit hypothesis be correct, then the parameter of interest, $\lambda$, is generally expected to be negative and statistically significant. However, at the subnational level in centralized countries, we argue that we should in fact expect no relationship given the mechanisms underlying the diversity debit hypothesis.

There are some important constraints with regard to estimating the effect of ethnic and linguistic diversity on public expenditure as formulated by equation (2). Ideally we would want to exploit the within-district variation to estimate equation (2) using fixed effects estimates in order to control for any unobserved district level characteristics that may affect central government allocation decisions. However, while we observe variation in the expenditure variables over time, the fractionalization indices as well as most covariates including poverty, district surface area, distance to Lusaka and the rural dummy are time-invariant.

Furthermore, budget allocations tend to be path dependent, with annual budget plans usually building incrementally on allocations in preceding fiscal years. Incremental budgeting implies that the expected errors are likely to be serially correlated over time.

Given these data constraints we resort to estimate equation (2) using a panel feasible GLS estimator that corrects for first order autocorrelation within panels. As a robustness check, we also estimate equation (2) with (i) a pooled ordinary least squares (OLS) estimator with standard errors corrected for correlation across panels, which allows for different structures of the error term, and ii) a pooled OLS estimator that assumes correlation across panels and more general serial correlation in the error, following the method of Driscoll and Kraay (1998) 


\subsection{The welfare outcomes model}

Regarding the relationship between ethnic diversity and welfare outcomes, we estimate two models. The first model measures the effect of ethnic or linguistic diversity on a number of education or health outcomes, after controlling for the district level covariates included in equation (2), and the effect of central government expenditure on education or health, respectively, which captures the government's decisions to allocate public funds to the districts, regardless of the size of the local population. The second model measures the effect of ethnic or linguistic diversity on the same welfare outcomes, after controlling for the same district level covariates and the effect of per capita expenditure, which now accounts for the effect of resource distribution across the local populations. More formally, the outcome equations take the following form:

$$
w_{i t}=\alpha_{i t}+\beta x_{i t}+\phi s_{i t}+\lambda f_{i}+\mu_{i}+\zeta_{t}+e_{i t}
$$

where, as before, the subscripts $i$ and $t$ denote district and year respectively; $w_{i t}$ measures the education and health outcomes; $x_{i t}$ is the vector of district level covariates derived in (2) that are expected to affect the welfare outcomes; $S_{i t}$ measures total (or per capita) government expenditure on education or health; and $f_{i}$ now measures ethnic or linguistic fractionalization. $\mu_{i}, \zeta_{t}, a, \beta, \phi$, and $\lambda$, are as defined above, whereas $e$ is the idiosyncratic error term.

The dominant diversity debit hypothesis would predict the parameter of interest, $\lambda$, to be negative and statistically significant. We note, however, that government expenditure is likely to be endogenous. It is reasonable to expect that welfare outcomes at district level are influenced by the allocation of public resources, as much as the decisions on how to distribute such resources is likely to be influenced by local demands and social needs. The presence of endogeneity would imply that $S_{i t}$ is correlated with $e_{i t}$, and therefore under an OLS framework, equation (2) would yield biased and inconsistent estimates. To test and address the endogeneity problem, we resort to instrumental variable estimators, including two stage least squares (2SLS), limited information maximum likelihood (LIML), generalized method of moments (GMM) to obtain, under a pooled cross-sectional setting, the following system of equations:

$$
\begin{aligned}
& s_{i t}=\alpha_{i t}+\beta x_{i t}+\lambda f_{i}+\delta \mathbf{z}_{i t}+\mu_{i}+\zeta_{t}+v_{i t} \\
& w_{i t}=\alpha_{i t}+\beta x_{i t}+\phi \hat{s}_{i t}+\lambda f_{i}+\mu_{i}+\zeta_{t}+v_{i t}
\end{aligned}
$$

where $\mathbf{Z}_{i t}$ is a vector of strictly exogenous instrumental variables that are partially correlated with $S_{i t}$, so the coefficient of $\mathbf{z}_{i t}$ is nonzero, i.e. $\delta \neq 0$ and $\operatorname{Cov}\left(\mathbf{z}_{i t}, v_{i t}\right) \neq 0$, while $\mathbf{z}_{i t}$ is uncorrelated with $w_{i t}$, so $\operatorname{Cov}\left(\mathbf{z}_{i t}, e_{i t}\right)=0$. Finding valid instruments thus becomes a crucial and complex task. We experiment with two general approaches: First, we exploit exogenous instrumental variables that have been used previously in the literature. Specifically, we use the logarithm of population, and the distance to the national capital, Lusaka, as external instruments. With regard to the former instrument, Easterly and Rebelo (1993) and Gebregziabher and Niño-Zarazúa (2014) find that the scale of the economy, measured by its population, is an important determinant of fiscal policy in general, and the allocation of social expenditure in particular. Yet, there is no reason to suspect that a particular district will achieve higher or lower levels of welfare simply because it has more 
or less people. The second instrument is based on the observation made in previous studies that more remote areas in Zambia tend to receive lower transfers from the central governments. Picazo and Zhao (2009), for instance, find that the most remote and least urbanized areas in Zambia receive the lowest per capita releases in the health sector (De Kemp et al. 2011). This could imply that there is a negative correlation between the distance to the capital city and the bargaining power that rural communities are able to exercise to attract public resources from the Centre; or that remote districts are sanctioned more frequently in financial terms if they fail to meet formal planning or reporting requirements. It is not entirely clear; however, whether more or less financial resources would necessarily lead to better or worse welfare outcomes, after controlling for poverty and the rural environment.

An initial examination of the pairwise correlations between government expenditure, both in total and in per capita terms, and the identified instruments show high correlations between the endogenous variables and the log of population, with most coefficients exciding $r>0.45$ values; however, the correlations become moderately low when using the distance to the capital city as instrument, with $r$ values ranging from 0.12 to 0.15 .

To verify the validity of the instruments, we follow Stock and Yogo (2005) to test for the concern of weak instruments that can lead to size distortions of the Wald test on the parameters. The results for education outcomes show that the Eigenvalue statistic and the F statistic comfortably exceed the critical values of the Stock and Yogo statistic at 5 per cent or 10 per cent for both the 2SLS and LIML models, which allows us to reject the null hypothesis of weak instruments, particularly for the case of $\log$ of population, but also when combined with distance to the capital city. While distance to the capital city alone appears as a weaker instrument than log of population when running the models of education outcomes, it becomes stronger when running the models of health outcomes, especially when health expenditure is instrumented in per capita terms (see Table 2). Therefore, we present the results in Section 5 and also in the Appendix using the individual and combined instrument sets.

Table 2: Stock-Yogo test for weak instruments

\begin{tabular}{|c|c|c|c|c|c|c|}
\hline \multirow{3}{*}{$\begin{array}{l}\text { Instrumented } \\
\text { variable } \\
\text { education expenditure }\end{array}$} & & \multicolumn{5}{|l|}{ Instruments } \\
\hline & & $\begin{array}{c}\text { log population + } \\
\mathrm{km} \text { to Lusaka }\end{array}$ & \multicolumn{2}{|c|}{ log population } & \multicolumn{2}{|c|}{$\mathrm{Km}$ to Lusaka } \\
\hline & F-statistic & 40.67 & \multicolumn{2}{|c|}{78.96} & \multicolumn{2}{|c|}{15.12} \\
\hline & Minimum Eigenvalue & 57.74 & \multicolumn{2}{|c|}{107.1} & \multicolumn{2}{|c|}{10.28} \\
\hline education expenditure & F-statistic & 77.46 & \multicolumn{2}{|c|}{145.6} & \multicolumn{2}{|c|}{3.947} \\
\hline per capita & Minimum Eigenvalue & 154.4 & \multicolumn{2}{|c|}{277.5} & \multicolumn{2}{|c|}{4.111} \\
\hline health & F-statistic & 43.43 & \multicolumn{2}{|c|}{65.55} & \multicolumn{2}{|c|}{18.61} \\
\hline expenditure & Minimum Eigenvalue & 36.64 & \multicolumn{2}{|c|}{49.37} & \multicolumn{2}{|c|}{25.81} \\
\hline health & F-statistic & 7.540 & \multicolumn{2}{|c|}{8.322} & \multicolumn{2}{|c|}{7.989} \\
\hline \multirow[t]{2}{*}{ expenditure per capita } & Minimum Eigenvalue & 11.04 & \multicolumn{2}{|c|}{4.293} & 15. & \\
\hline & & & $10 \%$ & $15 \%$ & $20 \%$ & $25 \%$ \\
\hline \multicolumn{3}{|c|}{ Critical Values 2SLS/LIML size of nominal $5 \%$ Wald Test } & 16.38 & 8.96 & 6.66 & 5.53 \\
\hline
\end{tabular}

Given the validity of the instruments, we resort to the Hausman procedure (Hausman 1978) to test for the assumption of endogeneity of government expenditure using equation (3) and (5) so $T H=\left(\hat{\phi}_{2 S L S}-\hat{\phi}_{\text {OLS }}\right)^{2} / \hat{V}\left(\hat{\phi}_{2 S L S}-\hat{\phi}_{\text {OLS }}\right)$ is $\chi^{2}(1)$ distributed under the null of exogeneity. As a robustness check, we also compute the Durbin-Wu-Hausman (DWH) test, which in addition produces robust test statistics (Davidson 2000). The Hausman and DWH results for government expenditure on education and health strongly reject the null of exogeneity for most outcome 
variables (see Tables in Appendix A). Therefore we conclude that government expenditure is endogenous and thus favour the use of instrumental variables estimators over OLS in the analysis.

Since we have longitudinal data, with most of the education and health outcomes being observed over the 2004-2009 period, we extend the analysis to system-GMM (SGMM) estimators in a dynamic setting, exploiting both the internally generated instruments, and also their combination with the external instruments. Under a dynamic framework, equation (5) can be rewritten as follows:

$$
w_{i t}=\alpha+\theta w_{i t-1}+\beta x_{i t}+\phi \hat{s}_{i t}+\lambda f_{i}+\mu_{i}+\zeta_{t}+v_{i t}
$$

where $W_{i t-1}$ and $\theta$ are the lag of the dependent variable and its parameter estimate, respectively. The presence of district fixed-effects, $\mu_{i}$, would suggest that the preferred approach is a fixed effects model, which would allow to mitigate the heterogeneity-induced bias and control for district-related endogeneity. However, the inclusion of lagged dependent variables would produce inconsistent fixed effects estimates. The Arellano and Bond (1991) first-differenced GMM (difGMM) estimator circumvent the endogeneity problem. However, the dif-GMM estimator suffers from large finite-sample bias and poor precision when time series are persistent. In such cases, the lagged levels of the series are weakly correlated with the lagged first differences, thereby making the instruments for the first-differenced equations weak (Blundell and Bond 1998).

The SGMM estimator developed by Blundell and Bond (1998) works around the weak instrument problem by solving a system of level and difference equations. Lagged differences of the endogenous variables are used as instruments in the level equations, while lagged levels of the endogenous variables are used as instruments in the first differenced equations. SGMM improves the accuracy of estimates by exploiting additional moment conditions that are informative in the presence of persistent data. Hence, we opt for a SGMM estimator with external instruments as our preferred model, the robustness of which we test using the internally generated set of instruments in a dynamic framework.

We note, however, that the additional moment conditions of the SGMM estimator do not come without a cost. The instruments for the level equations are valid as long as they are orthogonal to the fixed effects. In addition, SGMM may suffer from the weak instrument problem, particularly when the time series is large and substantial unobserved heterogeneity exists (Hayakawa 2007; Bun and Windmeijer 2010). Given the short time series of our data, we suspect this problem to be minimal, although we verify the SGMM results with the parameters obtained from the 2SLS, LIML, and GMM estimators.

Another potential deficiency of the SGMM estimators is that the number of internal instruments grows quadratically as the number of time periods increases. Roodman (2009) cautions that instrument proliferation can over-fit endogenous variables, biasing coefficient estimates and weakening the Hansen test of the instruments' joint validity. Therefore, we reduce the instrument count by 'collapsing' instruments which is superior to simply restricting the lag ranges. With all these caveats in mind, we present SGMM results in the following section. 


\section{$5 \quad$ Results}

\subsection{On ethnic diversity and public good provision}

Contrary to our expectations, but consistent with the general prediction of the diversity debit hypothesis, we find a clearly negative relationship between ethno-linguistic fractionalization and central government expenditure at district level in both sectors and across budget lines. Table 3 shows a summary of the panel regression results for each expenditure item in absolute as well as per capita terms for both fractionalization indices ELF-E and ELF-L. ${ }^{10}$ Besides ethno-linguistic fractionalization, the log of district population and the distance by road to Lusaka appear to be good predictors of differences in budget allocations between districts. As expected, the log of population has a highly significant positive coefficient in all specifications with total budget allocations, and a negative one for per capita allocations, except for per capita health spending. The distance to Lusaka is significant and negative throughout for total and per capita expenditure, except for grants to basic schools and health service delivery, where it is significant only in some model specifications. ${ }^{11}$

In contrast, and different from recent studies on fertilizer subsidies (Mason et al. 2013) or infrastructure projects (Leiderer 2014) in Zambia, the results do not provide particularly strong evidence for political targeting of health and education expenditure, with the vote share received by the ruling MMD insignificant in all specifications except for DEB allocations and total and per capita allocations for health service delivery (positive) and grants to basic schools (negative). ${ }^{12}$

Likewise, the poverty headcount is insignificant in most specifications, except for per capita grants to basic schools and total health allocations, and health service allocations, for which it has a (weakly significant) positive coefficient. This suggests that social sector expenditure was not markedly 'pro-poor' in Zambia during the second half of the past decade.

Table 3: Panel GLS regression results for health and education expenditure

\begin{tabular}{|c|c|c|}
\hline \multirow[b]{2}{*}{ Dependent variable } & \multicolumn{2}{|c|}{ Main explanatory variable } \\
\hline & ELF-E & ELF-L \\
\hline Total education expenditure & - & - \\
\hline Total education expenditure per capita & negative $^{*}$ & - \\
\hline DEB expenditure & negative ${ }^{* \star}$ & negative $^{\star *}$ \\
\hline DEB expenditure per capita & negative & negative ${ }^{\star \star}$ \\
\hline Basic schools expenditure & - & - \\
\hline Basic schools expenditure per capita & negative $^{*}$ & - \\
\hline Grants to basic schools & - & - \\
\hline Grants to basic schools per capita in relevant age group & - & - \\
\hline Teachers' salaries & - & - \\
\hline Teachers' salaries per capita in relevant age group & - & - \\
\hline Health expenditure & negative ${ }^{\star \star}$ & negative* \\
\hline Health expenditure per capita & - & - \\
\hline Health service expenditure & negative ${ }^{\star \star}$ & negative $^{\star \star}$ \\
\hline Health service expenditure per capita & negative ${ }^{\star \star}$ & negative $^{\star \star \star}$ \\
\hline
\end{tabular}

\footnotetext{
${ }^{10}$ Detailed regression results for ELF-E are reported in Appendix C.

${ }^{11}$ See Tables C4, C6, C7 in Appendix B.

12 See Tables C2, C4, C7 in Appendix C.
} 
As described above, we run as robustness checks the same equations with different specifications that allow for correlation across districts and autocorrelation of up to four lags. The alternative specifications produce very similar results with consistently smaller standard errors. ${ }^{13}$

The results from the model described in equation (2) may seem to confirm the diversity debit hypothesis that suggests a negative effect of local ethno-linguistic fractionalization on public goods provision via central government spending. However, it is prima facie not clear, by which mechanism local diversity should affect central government's spending decisions in a highly centralized governance system such as Zambia's.

One explanation for the observed pattern could be that it is not budget allocations, but the absorptive capacity of local districts that differs between districts with varying degrees of ethnolinguistic fractionalization. In Zambia, local offices of the central government ministries act as the central government's spending units at district level. The amount of money spent on public goods depends not only on the amount of resources the central government allocates to them, but also on the effectiveness and efficiency with which these spending units make use of the available resources. If the hypothesis that ethnic diversity leads to less efficient institutions and governance is correct, then we might expect the absorptive capacity of local spending units to be negatively correlated with ethnic diversity.

To control for this possibility, we estimate equation (2) with budget estimates as well as execution rates (i.e. the ratio between releases to each district education board, and district health management team, and their corresponding executed expenditure) as dependent variables. ${ }^{14}$

However, the findings, which are presented in Table 1 of Appendix C, do not support the absorptive capacity hypothesis. The results for budget estimates are strongly in line with those for actual expenditure figures, whereas the estimates for budget execution rates are insignificant throughout (Table 2 of Appendix C).

Taken together, our findings suggest that the observed negative relationship between ethnic fractionalization and central government spending is in fact due to allocation decisions taken at the central level and not because of differences in the absorptive capacity of the deconcentrated spending units at district level. Yet, as noted in the previous section, if ethnic fractionalization has a direct effect on welfare outcomes at district level, then it is likely that these allocation decisions are endogeneous. In this case we would expect the estimates in Table 3 to be biased and inconsistent. The second step of our analysis addresses this constraint.

\subsection{On ethnic diversity and welfare outcomes at subnational level}

In the second stage of our analysis we chose to follow studies such as Gerring et al. (2015), Miguel (2004), Miguel and Gugerty (2005) in studying the direct link between ethnic diversity and welfare outcomes.

\footnotetext{
13 Details not reported but available on request.

14 Budget execution rates vary substantially between districts and years. For overall education expenditure, the average execution rate in the sample is 99.3 per cent, with a standard deviation of 8.5 percentage points and a minimum value of 51.6 per cent and a maximum of 126 per cent. For health expenditure, the mean execution rate is 66 per cent (standard deviation 29 percentage points), with a minimum value of 1 per cent and a maximum of 130 per cent.
} 
Table 4 presents the OLS, 2SLS, GMM, and LIML regression results for ethnic fractionalization and welfare outcomes, and the full regression results are reported in Appendix D). Column 1 shows the coefficients on ELF-E with significance levels for robust standard errors for the OLS estimator. Columns 2-3 show the 2SLS estimates for education and health expenditure instrumented with the log of district population (column 2), the distance to Lusaka (column 3), and both instruments (column 4). Columns 5 and 6 show the GMM and LIML estimates using both instruments.

For the education sector, the results show a clearly positive relationship across specifications between ethnic fractionalization and primary school enrolment, but none with the other outcome variables. For the health sector, the results are in line with those obtained from the education sector: there is a positive effect of ethnic diversity on all immunization rates and the share of underweight children under five (where a negative sign means a reduction in underweight). The coefficients on maternal mortality and under five mortality also have the expected negative sign, but are statistically insignificant. The only exception is total beds in health facilities.

Given the specific setup of Zambia's health system, health indicators capture allocation decisions at different levels of government. Procurement of medical supplies, capital investment and staff allocations are the responsibility of the Ministry of Health, whereas the DHMTs are responsible for service delivery at district level (ILO 2008). It is thus not surprising that the coefficient for beds in health facilities is negative, as it is most likely driven by decisions taken at the central government level. The results for outcomes such as immunization are more likely to be driven by decisions at the local level, whereas staffing of health facilities is determined by central and local decision-making (Bossert et al. 2003).

The results are highly robust across the various model specifications and the selection of instruments for government expenditure. Moreover, the effects are comparable in terms of magnitude and direction across models. A one standard deviation increase in the ethnic fractionalization index leads to an increase of the primary school enrolment rate of between 5.7 and 6.9 percentage points. The effect of ethnic diversity on immunization rates is of comparable magnitude at between 4.1 percentage points (for BCG immunization rates in the GMM specification) and 8.2 percentage points (for fully immunized children in the 2SLS specification with only distance to Lusaka as instrument). The same increase in the ethnic fractionalization index reduces the number of underweight children per 100 weighed children under 5 by between 2.9 to 3.2 .

Controlling for per capita rather than total expenditure does not alter the results for health substantially (see Table D1 in Appendix D), with the exception of individual vaccination rates in the 2SLS specification with only the (log) population instrument and the LIML model (except BCG immunization, which remains significant). For education, ELF-E becomes positive and significant for both lower secondary school enrolment and the number of schools in 2008 across all specifications (except number of schools 2008 in the 2SLS model with distance to Lusaka as the only instrument). 
Table 4: Overview of regressions results for ethnic fractionalization and social sector outcomes

\begin{tabular}{|c|c|c|c|c|c|c|}
\hline Method & OLS & $2 S L^{a}$ & $2 S L^{b}$ & $2 S L S^{c}$ & $\mathrm{GMM}^{c}$ & LIML $^{c}$ \\
\hline Dependent variable & \multicolumn{6}{|c|}{ Coefficient on ELF-E } \\
\hline $\begin{array}{l}\text { Primary school } \\
\text { enrolment }\end{array}$ & $.261^{\star \star \star}$ & $.305^{\star \star \star}$ & $.249^{\star \star \star}$ & $.300^{\star \star *}$ & $.304^{\star \star \star}$ & $.303^{\star \star \star}$ \\
\hline $\begin{array}{l}\text { Lower secondary } \\
\text { enrolment }\end{array}$ & .046 & .090 & -.002 & .082 & .037 & .089 \\
\hline $\begin{array}{l}\text { Teacher-pupil ratio } \\
\text { (2008) }\end{array}$ & .001 & .003 & -.004 & .002 & .003 & .003 \\
\hline $\begin{array}{l}\text { Number of schools } \\
(2008)\end{array}$ & -14.156 & -40.042 & -22.264 & -38.088 & -35.096 & -38.644 \\
\hline $\begin{array}{l}\text { Number of teachers } \\
\text { (2008) }\end{array}$ & 84.765 & -62.003 & -157.748 & -72.526 & -91.064 & -74.558 \\
\hline $\begin{array}{l}\text { Teacher-pupil ratio in } \\
\text { basic schools (2009) }\end{array}$ & .003 & .003 & .003 & .003 & .003 & .003 \\
\hline $\begin{array}{l}\text { Number of basic schools } \\
(2009)\end{array}$ & 12.332 & 10.433 & 10.218 & 10.428 & 10.081 & 10.428 \\
\hline Total beds & $-1.546^{\star \star \star}$ & $-1.559^{\star \star}$ & $-1.529^{\star \star}$ & $-1.554^{\star \star \star}$ & $-2.193^{\star \star \star}$ & $-1.558^{\star \star \star}$ \\
\hline Health Centre Staff p.c. & $2.614^{\star \star \star}$ & $2.597^{\star \star \star}$ & $2.656^{\star \star \star}$ & $2.608^{\star \star \star}$ & $2.441^{\star \star \star}$ & $2.542^{*}$ \\
\hline Hospital OPD Staff p.c. & $.288^{\star}$ & $.337^{\star}$ & .250 & $.314^{*}$ & .079 & $.323^{\star}$ \\
\hline BCG immunization & $.190^{\star \star \star}$ & $.191^{\star \star \star}$ & $.192^{\star \star \star}$ & $.191^{\star \star \star}$ & $.180^{\star \star \star}$ & $.191^{\star \star \star}$ \\
\hline DPT3 immunization & $.240^{\star \star \star}$ & $.241^{\star \star \star}$ & $.244^{\star \star \star}$ & $.242^{\star \star \star}$ & $.230^{\star \star \star}$ & $.242^{\star \star \star}$ \\
\hline OPV3 immunization & $.272^{\star \star \star}$ & $.273^{\star \star \star}$ & $.276^{\star \star *}$ & $.273^{\star \star \star}$ & $.268^{\star \star \star}$ & $.274^{\star \star \star}$ \\
\hline Measles immunization & $.205^{\star \star \star}$ & $.206^{\star \star \star}$ & $.206^{\star \star \star}$ & $.206^{\star \star \star}$ & $.206^{\star \star \star}$ & $.206^{\star \star \star}$ \\
\hline FIC immunization & $.361^{\star \star \star}$ & $.361^{\star \star \star}$ & $.363^{\star \star \star}$ & $.361^{\star \star \star}$ & $.367^{\star \star \star}$ & $.362^{\star \star \star}$ \\
\hline Maternal mortality & -64.905 & -63.855 & -74.029 & -65.886 & -164.207 & -66.035 \\
\hline Under 5 mortality & -7.793 & -7.793 & -7.350 & -7.709 & -15.641 & -7.684 \\
\hline Underweight under 5 & $-12.877^{\star \star \star}$ & $-12.875^{\star \star \star}$ & $-12.908^{\star \star \star}$ & $-12.881^{\star \star \star}$ & $-13.323^{\star \star *}$ & $-12.882^{\star \star \star}$ \\
\hline
\end{tabular}

Notes: values show estimated coefficient for ethnic fractionalization index ELF-E; ${ }^{a}$ instruments for central government expenditure using log population; ${ }^{b}$ instruments for central government expenditure using distance from district capital to Lusaka; ${ }^{c}$ instruments for central government expenditure using log population and distance from district capital to Lusaka. ${ }^{\star} p<0.10,{ }^{* \star} p<0.05,{ }^{\star \star \star} p<0.01$ for robust standard errors.

With most of the education and health outcomes being observed over various years, we extend the analysis to include SGMM estimators in a dynamic setting. Table 5 shows the SGMM estimates for the coefficient on ethnic fractionalization in different specifications with lagged dependent variables (columns 1-4) and without lagged dependent variables and the two external instruments, jointly and individually, inputted (columns 5-8). Individual regression tables for each outcome variable are reported in Appendix E.

The SGMM results show similar results in terms of direction, although for education outcomes the strength of the association is much weaker, with only primary school enrolment exhibiting a significant and positive effect in the specifications without the lagged dependent variable as an explanatory variable. For the health sector, however, the results remain fairly robust, with ethnic fractionalization having a strong and positive effect on immunization rates and a reduction in the number of underweight children under the age of five. ${ }^{15}$

\footnotetext{
15 Including the ruling party's vote share as an additional endogenous regressor does not substantially alter the results, but slightly increases coefficients on ethnic fractionalization and significance levels. In addition, the Sargan-Hansen tests of overidentifying restrictions perform somewhat better in individual specifications. The results reported here, therefore, arguably represent conservative estimates of the effect of ethnic fractionalization.
} 
Table 5: Overview results of SGMM estimation for ethnic fractionalization and all outcomes with total sector expenditure

\begin{tabular}{|c|c|c|c|c|c|c|c|c|}
\hline \multirow[b]{2}{*}{ Model } & \multicolumn{5}{|c|}{$\begin{array}{l}\text { with lagged dependent variable as } \\
\text { regressor }\end{array}$} & \multicolumn{3}{|c|}{$\begin{array}{l}\text { without lagged dependent variable as } \\
\text { regressor }\end{array}$} \\
\hline & $(1)^{a}$ & $(2)^{b}$ & $(3)^{c}$ & $(4)^{d}$ & $(5)^{a}$ & $(6)^{b}$ & $(7)^{c}$ & $(8)^{d}$ \\
\hline \multicolumn{9}{|l|}{ Dependent variable } \\
\hline Prim. school enrolment & .033 & .032 & .037 & .031 & $.250^{*}$ & $.253^{*}$ & $.263^{\star}$ & .230 \\
\hline Lower sec. enrolment & -.004 & .007 & .011 & -.006 & .001 & .024 & .024 & -.016 \\
\hline Total beds $^{\dagger}$ & $-1.156^{\star \star}$ & -.338 & -.496 & $-.772^{\star}$ & $-1.409^{\star \star}$ & $-1.657^{\star \star}$ & $-1.698^{\star \star \star}$ & $-1.666^{\star \star \star}$ \\
\hline Health Centre staff p.c. & .524 & -.016 & .402 & -.002 & $2.625^{\star \star}$ & $3.058^{\star \star}$ & $2.892^{\star *}$ & $3.096^{\star \star}$ \\
\hline Hospital OPD staff p.c. & -.001 & -.065 & -.084 & .001 & -.098 & .140 & .166 & -.086 \\
\hline BCG immunization & .116 & .131 & .120 & $.140^{\star}$ & $.157^{\star}$ & .160 & $.152^{*}$ & $.180^{\star}$ \\
\hline DPT3 immunization & $.185^{\star \star}$ & $.102^{*}$ & $.135^{\star \star}$ & $.117^{\star}$ & $.326^{\star \star \star}$ & $.256^{\star \star}$ & $.240^{\star *}$ & $.281^{\star *}$ \\
\hline OPV3 immunization & $.244^{\star \star \star}$ & $.151^{\star}$ & $.193^{\star \star}$ & $.151^{\star}$ & $.305^{\star \star \star}$ & $.289^{\star \star}$ & $.243^{\star \star}$ & $.301^{\star *}$ \\
\hline Measles immunization & $.213^{\star \star}$ & $.189^{\star \star}$ & $.188^{\star \star}$ & $.197^{\star \star}$ & $.240^{\star \star}$ & $.226^{\star \star}$ & $.220^{\star \star}$ & $.236^{*}$ \\
\hline FIC immunization & $.309^{\star \star \star *}$ & $.201^{\star *}$ & $.309^{* \star \star}$ & $.189^{\star \star}$ & $.356^{\star \star \star}$ & $.422^{\star \star \star}$ & $.362^{\star \star \star}$ & $.415^{\star \star \star}$ \\
\hline Maternal mortality & -65.067 & 15.371 & -64.656 & 4.122 & -75.981 & -35.492 & -84.540 & -32.653 \\
\hline Under 5 mortality & -8.103 & -8.543 & -9.822 & -10.369 & -16.443 & -13.282 & -12.398 & -20.333 \\
\hline Underweight under 5 & 2.989 & .547 & 2.954 & .844 & $-11.765^{\star \star \star}$ & $-12.456^{\star \star \star}$ & $-12.092^{\star \star \star}$ & $-11.593^{\star \star \star}$ \\
\hline
\end{tabular}

Notes: values show estimated coefficient for ethnic fractionalization index ELF-E; ${ }^{a}(1)$ and (5) use only internal instruments (second and longer lags of central government education/health expenditure); ${ }^{b}(2)$ and (6) use both internal and external (log population and distance from district capital to Lusaka) instruments; ${ }^{c}(3)$ and (7) use internal and one external (log population) instrument; ${ }^{d}(4)$ and (8) use internal and one external (distance to Lusaka) instrument. ${ }^{*} p<0.10,{ }^{* \star} p<0.05,{ }^{* \star *} p<0.01$ for robust standard errors. 
Tables E16 to E30 in Appendix E present the results from the SGMM equations instrumenting for per capita expenditure. With per capita expenditure, ethnic fractionalization becomes insignificant for primary school enrolment, whereas for health outcomes the results remain highly robust.

Running the SGMM models with ELF-L instead of ELF-E yields very similar results, with slightly larger coefficients for ELF-L than for ELF-E (see Table E32 in Appendix E).

Overall, we find strong evidence for a positive effect of ethno-linguistic fractionalization on health outcomes at district level in Zambia, particularly on immunization rates, and under five mortality and underweight children. The results for the education sector are also consistent with our priors, although somewhat less robust than the health outcomes results.

\section{Conclusion}

The findings in this study challenge the conventional wisdom that ethnic diversity leads to the under-provision of public goods, a hypothesis that has been applied particularly to understanding development outcomes in sub-Saharan Africa. Using district level data for Zambia across a wider range of indicators than analyzed in previous work on the region, we show that ethnic fractionalization is not clearly associated with the under-provision of public goods and, indeed, has a positive relationship with key welfare outcomes. These findings are consistent with an emerging body of work challenging the diversity debit hypothesis on empirical grounds. Indeed, contra Habyarimana et al. (2007), the empirical record suggests that the key question for future work in this area is not so much 'why does ethnic diversity undermine public goods provision,' but when and, in particular, why does it not? How do we explain the diversity dividend that has now been documented in multiple subnational empirical studies? Here we consider several possible explanations for what we find in Zambia.

One now well-rehearsed response is that ethnic diversity does not undermine public goods provision when 'diversity' is not equivalent to 'division'- put another way, it is ethnic division, not diversity per se that drives the diversity debit hypothesis. Miguel (2004), for instance, has shown in comparative analysis of communities in Tanzania to those in Kenya-where national identity versus ethnic identity is comparatively strong and vice versa- that the negative relationship between ethnic divisions and public goods provision holds only in the latter context, while Singh (2010) shows with longitudinal analysis of social development in Kerala that it is not diversity per se, but the absence of a subjective sense of 'we-ness,' that drives negative outcomes. Convincing as this work is, this response does not get us very far in explaining the Zambian findings. While this line of argument speaks to the absence of a negative relationship, it does not explain the presence of a positive one.

Two explanations from the literature speak directly to the positive relationship. Gerring et al. (2015) argue that it may be that ethnic division does indeed have a negative impact (as they show at the national level) but that this effect is counteracted at the subnational level by other factors. In particular, they highlight two mechanisms. One mechanism concerns how 'scale' may play a role in making subnational communities more likely to realize the benefits of diversity (see, Blinder and Morgan 2005; Charness and Sutter 2012: 174; Lombardelli et al. 2005; Page, 2007; Surowiecki, 2004). For example, we see in other contexts that local communities can coordinate to provide common pool resources, but such informal mechanisms may be unlikely to function at the national level (Ostrom 1990). With respect to the Zambian case, however, the size of the subnational units in question (districts) raises questions for us about whether community politics at this scale really 
benefit from the sort of coordination Ostrom shows: her focus is explicitly on 'small-scale CPRs [common pool resources], where ... the number of individuals affected varies from 50 to 15,000 persons who are heavily dependent on the CPR for economic reasons' (Ostrom 1990). District level governance in Zambia operates on larger scale and without the same economic incentives.

A second factor Gerring et al. (2015) highlight is 'optimal sorting,' which they posit is more likely at the subnational level because people can more freely move within a country than across national borders, making diversity at subnational levels more a matter of choice than birth. At the subnational level 'people who wish to live together are more likely to be able to do so' and 'those who choose to relocate to diverse areas - rather than staying put or relocating to an ethnic enclave comprised of persons with similar backgrounds-are likely to be more ambitious, more skilled, and more highly educated (Borjas 1998; Damm 2009) —and, one might add, less averse to living amidst diversity' (Gerring et al. 2015). In other words, variations in ethnic heterogeneity at the subnational level may be less likely to operate according to the 'negative' mechanisms outlined above.

In Zambia, it is clear that internal migration (namely, urbanization) has been high-between 1964 and 1990, for instance, the urban population increased from 10.5 to 39.4 per cent-suggesting at least the plausibility of 'optimal sorting' (Zulu 2000). That said, we would expect the role in our sample to be relatively minor because our analysis in fact excludes the four cities in the samplepresumably where the most ambitious, pro-diversity migrants would prefer to go. To the extent that we would expect those in rural and municipal districts not to be so different from each other, optimal sorting seems unlikely to be the main explanatory factor. However, further research would be useful to more fully understand migrants' decisions to migrate and whether more urban migrants in fact have different attitudes with respect to diversity than those who stayed put or moved to more homogeneous areas.

It is also worth highlighting that at least one scholar of Zambia has argued along conflicting lines that the process of urbanization in sub-Saharan Africa more generally has been part and parcel of increasing ethnically-based identification and competition (Bates 1974). In Bates's argument, this competition centers on the 'goods of modernity'-education and jobs in particular. This argument appears broadly consistent with our finding that outcomes that require the active participation of target groups, such as primary school enrolment and children's immunization rates, are positively correlated with ethnic fractionalization. This could be an indication that the population in more heterogeneous local communities may demand and make use of public services more actively than in more homogeneous ones, for instance as a result of more intense inter-group competition in local labour markets.

Another explanation for the positive relationship between ethnic diversity and public goods provision - which has been applied directly on the Zambian case - is Gibson and Hoffman (2013)'s that 'political institutions' - namely, electoral systems - 'can create incentives for politicians to work across ethnic lines, even where ethnicity is a salient political factor.' To be reelected, politicians need to deliver benefits to constituents, which in turn provide incentives for them to form coalitions to pass policy. Building on Bawn and Rosenbluth (2006)'s findings on political fragmentation and government expenditure, they propose that just as public expenditure increases with the number of parties, it should also increase with ethnic diversity. While this argument offers important traction on explaining the district level spending analyzed by Gibson and Hoffman, it does not offer clear predictions with respect to our key finding that central government expenditure is negatively correlated with ethnic fractionalization, whereas outcomes improve with fractionalization. 
Interestingly, however, Gibson and Hoffman's empirical findings suggest another explanation for our finding of a statistically significant negative relationship between ethnic fractionalization and budget allocations: As noted above, we would not have expected district level ethnic fractionalization to directly influence national budget allocations. However, it might do so indirectly. In particular, to the extent that ethnic fractionalization has an observed positive relationship with district level outputs and outcomes, it may indirectly lead to lower allocations to these 'less needy' districts. Our analysis strongly supports this argument as we find central government expenditure to be endogenous in our econometric model. ${ }^{16}$

Another interpretation of our findings links to the extensive literature on neopatrimonial regimes in Africa. The concept of neopatrimonialism stresses the lack of effective checks and balances in the public sector, the importance of informal rules and institutions for the distribution of public resources and the capture of these resources by elites and leaders to maintain extended clientelistic networks and patronage systems (Bratton and van de Walle 1994; Erdmann and Simutanyi 2003; Leiderer et al. 2007; von Soest 2007).

If, in the absence of effective accountability mechanisms in the formal governance system, resources transferred from central government in Zambia are subject to such capture by local groups, then one might expect informal local rules and institutions to be important determinants of the extent to which such capture takes place in a particular district. Various studies suggest that some form of local capture through informal process may indeed be happening at district level in Zambia. In a World Bank Public Expenditure Review for the Zambian health sector in 2008, Picazo and Zhao (2009) argue that while it is possible to trace resources from the Ministry of Health to the districts, how allocation decisions are taken within the district health management teams remains a 'black box' and does not form part of the formal 'fiscal information chain'. In a limited sample their study finds that only 50 per cent of reviewed health centers received their full allocations (see Leiderer et al. 2012).

Several informal processes would be consistent with the positive relationship we find between ethnic diversity and public goods outcomes. For instance, if one assumes that central government transfers captured by local leaders are not used for the provision of public goods but mainly for private consumption and patronage spending on each leader's own group, then each group might have a strong incentive to curtail such capture by competing groups. It can be expected that whether one group can effectively keep another other one from misappropriating public resources aimed at funding public goods, strongly depends on the relative size of these groups.

One would thus expect 'informal' checks and balances at local level to work more effectively across more diverse communities of comparable size than when a local community is dominated by only one large group or a small number of groups that may collude in diverting public resources. In this case one would expect capture of public resources for private consumption or patronage spending to be more prevalent in more homogeneous districts than in those with a more diverse population. Vice versa, in more heterogeneous societies, where informal checks and balances between ethnic groups and their traditional leaders exist, and no single dominant group (or their leader) is able to capture a major share of central government transfers, a larger share of central government transfers will be available for the provision of public goods and services. As a result, one would

16 As Gibson and Hoffman's (2013) analysis suggests, there may also be a positive relationship between ethnic fractionalization and district council revenues and spending, which - even if only a minor share of the total budget could also help to explain the negative sign in our results on allocations. 
thus expect better welfare outcomes for given levels of central government spending in ethnically more diverse communities than in more homogeneous ones. This line of argument seems to be consistent with the recent experimental findings of Levine et al. (2014) who suggest that ethnic diversity prevents detrimental herding behaviour and fosters greater inter-group scrutiny, which in turn leads to better outcomes.

None of these diverse explanations alone is fully satisfactory in explaining our empirical findings, but together they speak to why ethnic diversity does not necessarily undermine public goods provision at local level.

\section{References}

Alesina, A., R. Baqir, and W. Easterly (1999). 'Public Goods and Ethnic Divisions'. The Quarterly Journal of Economics. 114 (4): 1243-1284.

Alesina, A. and E. La Ferrara (2000). 'Participation in Heterogeneous Communities'. The Quarterly Journal of Economics. 115 (3): 847-904.

Arellano, M. and S. Bond (1991). 'Some Tests of Specification for Panel Data: Monte Carlo Evidence and an Application to Employment Equations'. The Review of Economic Studies. 58 (2): 277-297.

Ashraf, Q. and O. Galor (2013a). 'Genetic Diversity and the Origins of Cultural Fragmentation'. American Economic Review. 103 (3): 528-533.

Ashraf, Q. and O. Galor (2013b). 'The 'Out of Africa' Hypothesis, Human Genetic Diversity, and Comparative Economic Development’. American Economic Review. 103 (1): 1-46.

Bahry, D., M. Kosolapov, P. Kozyreva, and R.K. Wilson (2005). 'Ethnicity and Trust: Evidence from Russia'. The American Political Science Review. 99 (4): 521-532.

Baldwin, K. and J.D. Huber (2010). 'Economic versus Cultural Differences: Forms of Ethnic Diversity and Public Goods Provision'. American Political Science Review. 104 (04): 644-662.

Banerjee, A., L. Iyer, and R. Somanathan (2005). 'History, Social Divisions, and Public Goods in Rural India'. Journal of the European Economic Association. 3 (2-3): 639-647.

Bates, R. (1974). 'Ethnic Competition and Modernization in Contemporary Africa'. Comparative Political Studies. (January): 457-483.

Bawn, K. and F. Rosenbluth (2006). 'Short versus Long Coalitions: Electoral Accountability and the Size of the Public Sector'. American Journal of Political Science. 50 (2): 251-265.

Blinder, A.S. and J. Morgan (2005). 'Are Two Heads Better than One? Monetary Policy by Committee'. Journal of Money, Credit and Banking, 37(5), 798-811.

Blundell, R. and S. Bond (1998). 'Initial Conditions and Moment Restrictions in Dynamic Panel Data Models'. Journal of Econometrics. 87 (1): 115-143.

Boix, C. and D.N. Posner (1998). 'Social Capital: Explaining Its Origins and Effects on Government Performance'. British Journal of Political Science. 28 (4): 686-693.

Borjas, G. J. (1998). 'To Ghetto or not to Ghetto: Ethnicity and Residential Segregation'. Journal of Urban Economics, 44(2), 228-253.

Bossert, T., M.B. Chitah, and D. Bowser (2003). 'Decentralization in Zambia: Resource Allocation and District Performance'. Health Policy and Planning. 18 (4): 357-369. 
Bratton, M. and N. van de Walle (1994). 'Neopatrimonial Regimes and Political Transitions in Africa'. World Politics. 46 (04): 453-489.

Bun, M.J.G. and F. Windmeijer (2010). 'The Weak Instrument Problem of the System GMM Estimator in Dynamic Panel Data Models'. Econometrics Journal. 13 (1): 95-126.

Chandra, K. (2001). 'Ethnic Bargains, Group Instability, and Social Choice Theory'. Politics and Society. 29 (3): 337-362.

Charness, G. and M. Sutter (2012). 'Groups Make Better Self-interested Decisions'. Journal of Economic Perspectives, 26(3), 157-176.

Damm, A. P. (2009). 'Ethnic Enclaves and Immigrant Labor Market Outcomes: Quasiexperimental Evidence'. Journal of Labor Economics, 27(2), 281-314.

Davidson, J. (2000). Econometric Theory. Oxford: Wiley-Blackwell.

De Kemp, A., J. Faust, and S. Leiderer (2011). Between High Expectations and Reality: An Evaluation of Budget Support in Zambia (2005-2010). Bonn / the Hague / Stockholm: German Federal Ministry for Economic Cooperation and Development / Ministry of Foreign Affairs of The Netherlands / Swedish International Development Cooperation Agency.

Deutsch, K. (1966). Nationalism and Social Communication. Cambridge, MA: MIT Press.

Driscoll, J.C. and A.C. Kraay (1998). 'Consistent Covariance Matrix Estimation with Spatially Dependent Panel Data'. Review of Economics and Statistics. 80 (4): 549-560.

Easterly, W. and R. Levine (1997). 'Africa's Growth Tragedy: Policies and Ethnic Divisions'. The Quarterly Journal of Economics. 112 (4): 1203-1250.

Easterly, W. and S. Rebelo (1993). 'Fiscal Policy and Economic Growth'. Journal of Monetary Economics. 32 (3): 417-458.

Erdmann, G. and N. Simutanyi (2003). Transition in Zambia. The Hybridisation of the Third Republic. Lilongwe: Konrad Adenauer Foundation.

Franck, R. and I. Rainer (2012). 'Does the Leader's Ethnicity Matter? Ethnic Favoritism, Education, and Health in Sub-Saharan Africa'. American Political Science Review. 106 (02): 294325.

Gebregziabher, F. and M. Niño-Zarazúa (2014). 'Social Spending and Aggregate Welfare in Developing and Transition Economies'. WIDER Working Paper 2014/082.

Gerring, J., S.C. Thacker, Y. Lu, and W. Huang (2015). 'Does Diversity Impair Human Development? A Multi-Level Test of the Diversity Debit Hypothesis'. World Development. 66 (0): 166-188.

Gibson, C.C. and B.D. Hoffman (2013). 'Coalitions not Conflicts: Ethnicity, Political Institutions, and Expenditure in Africa'. Comparative Politics. 45 (3): 273-290.

Gisselquist, R.M. (2014). 'Ethnic Divisions and Public Goods Provision, Revisited'. Ethnic and Racial Studies. 37 (9): 1605-1627.

Gisselquist, R.M. and O.S. McDoom (2014). 'The Conceptualization and Measurement of Ethnic and Religious Divisions: Categorical, Temporal, and Spatial Dimensions of Diversity with Evidence from Mindanao, the Philippines '. Helsinki: UNU-WIDER.

Gormley, W.T. (2007). 'Public Policy Analysis: Ideas and Impacts'. Annual Review of Political Science. 10 (1): 297-313. 
Habyarimana, J., M. Humphreys, D.N. Posner, and J.M. Weinstein (2007). 'Why Does Ethnic Diversity Undermine Public Goods Provision?’. American Political Science Review. 101 (4): 709725 .

Hausman, J.A. (1978). 'Specification Tests in Econometrics.'. Econometrica. 46 (6): 1251-1271.

Hayakawa, K. (2007). 'Small Sample Bias Properties of the System GMM Estimator in Dynamic Panel Data Models'. Economics Letters. 95 (1): 32-38.

ILO (2008). Zambia: Social Protection Expenditure and Performance Review and Social Budget. Geneva: International Labour Organization.

IOB (2008). Primary Education in Zambia. The Hague: Policy and Operations Evaluation Department.

Jackson, K. (2013). 'Diversity and the Distribution of Public Goods in Sub-Saharan Africa'. Journal of African Economies. 22 (3): 437-462.

Khwaja, A.I. (2009). 'Can Good Projects Succeed in Bad Communities?'. Journal of Public Economics. 93 (7-8): 899-916.

Kimenyi, M.S. (2006). 'Ethnicity, Governance and the Provision of Public Goods'. Journal of African Economies. 15 (Suppl 1): 62-99.

Leiderer, S. (2014). 'Who gets the Schools? Political Targeting of Economic and Social Infrastructure Provision in Zambia'. Discussion Paper 27/201. Bonn: German Development Institute / Deutsches Institut für Entwicklungspolitik (DIE).

Leiderer, S., M. Geigenmüller, A. Hornig, K. Kästle, C. Smith, and F. Tröger (2012). 'Efficiency of Service Provision at Local Government Level in Zambia in Health, Education and Roads: Implications for Decentralisation and the Effectiveness of Budget Support'. Studies. Bonn: Deutsches Institut für Entwicklungspolitik (DIE) / German Development Institute.

Leiderer, S., B. Hodick, E. Kabey, M. Roll, S. Schnitzer, and J. Ziegenbein (2007). 'Public Financial Management for PRSP Implementation in Malawi - Formal and Informal PFM Institutions in a Decentralising System'. Bonn: Deutsches Institut für Entwicklungspolitik / German Development Institute.

Levine, S.S., E.P. Apfelbaum, M. Bernard, V.L. Bartelt, E.J. Zajac, and D. Stark (2014). 'Ethnic Diversity Deflates Price Bubbles'. Proceedings of the National Academy of Sciences.

Lijphart, A. (2012). Patterns of Democracy: Government Forms and Performance in Thirty-six Countries. New Haven, CT: Yale University Press.

Lindemann, S. (2011a). 'The Ethnic Politics of Coup Avoidance: Evidence from Zambia and Uganda'. Africa Spectrum. 46 (2): 3-41.

Lindemann, S. (2011b). 'Inclusive Elite Bargains and the Dilemma of Unproductive Peace: A Zambian Case Study'. Third World Quarterly. 32 (10): 1843-1869.

Lombardelli, C., Proudman, J. and J. Talbot (2005). 'Committees versus Individuals: An Experimental Analysis of Monetary Policy Decision Making'. International Journal of Central Banking, 1(1), 181-205.

Mason, N.M., T.S. Jayne, and N. van de Walle (2013). 'Fertilizer Subsidies and Voting Patterns: Political Economy Dimensions of Input Subsidy Programs'. Selected Paper prepared for Presentation at the Agricultural \& Applied Economics Association's 2013 AAEA \& CAES Joint Annual Meeting, Washington, DC, August 4-6 2013. 
Miguel, E. (2004). 'Tribe or Nation? Nation Building and Public Goods in Kenya versus Tanzania'. World Politics. 56 (3): 327-362.

Miguel, E. and M.K. Gugerty (2005). 'Ethnic Diversity, Social Sanctions, and Public Goods in Kenya'. Journal of Public Economics. 89 (11-12): 2325-2368.

Ostrom, E. (1990). Governing the Commons: The Evolution of Institutions for Collective Action. Cambridge: Cambridge University Press.

Page, S.E. (2007). The Difference: How the Power of Diversity Creates better Groups, Firms, Schools, and Societies. Princeton, NJ: Princeton University Press.

Picazo, O. and F. Zhao (2009). 'Zambia Health Sector Public Expenditure Review'. Washington, DC: World Bank.

Posner, D.N. (2004). 'Measuring Ethnic Fractionalization in Africa'. American Journal of Political Science. 48 (4): 849-863.

Posner, D.N. (2005). Institutions and Ethnic Politics in Africa. Cambridge: Cambridge University Press.

Putnam, R.D. (1993). Making Democray Work: Civic Traditions in Modern Italy. Princeton, NJ: Princeton University Press.

Putnam, R.D. (2007). 'E Pluribus Unum: Diversity and Community in the Twenty-first Century The 2006 Johan Skytte Prize Lecture'. Scandinavian Political Studies. 30 (2): 137-174.

Republic of Zambia (2000). 'Zambia 2000 Census of Population and Housing: Enumerator's Instruction Manual'. Lusaka.

Republic of Zambia (2008). 'Zambia Public Financial Management Report and Performance Indicators. 2008 Assessment and Update'.

Roodman, D. (2009). 'A Note on the Theme of Too Many Instruments'. Oxford Bulletin of Economics and Statistics. 71 (1): 135-158.

Singh, P. (2010). 'We-ness and Welfare: A Longitudinal Analysis of Social Development in Kerala, India'. World Development. 39 (2): 282-293.

Stock, J.H. and M. Yogo (2005). Testing for Weak Instruments in Linear IV Regression'. In D.W.K. Andrews and J.H. Stock (eds), Identification and Inference for Econometric Models. New York: Cambridge University Press.

Surowiecki, J. (2004). The Wisdom of Crowds: Why the Many are Smarter than the Few and How Collective Wisdom Shapes Business, Economies, Societies, and Nations. New York: Doubleday.

von Soest, C. (2007). 'How does Neopatrimonialism Affect the African State's Revenues? The Case of Tax Collection in Zambia'. The Journal of Modern African Studies. 45 (04): 621-645.

Waring, T.M. (2012). 'Cooperation Dynamics in a Multiethnic Society: A Case Study from Tamil Nadu'. Current Anthropology. 53 (5): 642-649.

Wimmer, A., L.-E. Cederman, and B. Min (2009). 'Ethnic Politics and Armed Conflict: A Configurational Analysis of a New Global Data Set'. American Sociological Review. 74 (2): 316337.

World Bank (2008). 'Making Basic Education Services More Effective In Zambia: Improving Delivery, Tracking School Level Expenditures'. Washington, DC.

Zulu, R. (2000). 'Migration and Development in Zambia'. Montreaux, Switzerland. 


\section{Appendix A}

Table A1: Robustified Durbin-Wu-Hausman and Hausman tests for endogeneity

\begin{tabular}{|c|c|c|c|}
\hline \multirow[b]{2}{*}{$\begin{array}{c}\text { Outcome variables and } \\
\text { key statistics }\end{array}$} & \multicolumn{3}{|c|}{ Instruments } \\
\hline & $\begin{array}{c}\text { Log population } \\
+ \\
\mathrm{km} \text { to Lusaka }\end{array}$ & Log population & km to Lusaka \\
\hline \multicolumn{4}{|c|}{ primary school enrolment: total expenditure } \\
\hline$x^{2}$-statistic $p$-value & 0.000 & 0.000 & 0.534 \\
\hline F-statistic p-value & 0.000 & 0.000 & 0.539 \\
\hline Hausman $x 2 p$-value & 0.000 & 0.000 & 0.547 \\
\hline \multicolumn{4}{|c|}{ primary school enrolment: per capita expenditure } \\
\hline$x^{2}$-statistic $p$-value & 0.001 & 0.001 & 0.813 \\
\hline F-statistic p-value & 0.000 & 0.001 & 0.816 \\
\hline Hausman $x 2 p$-value & 0.001 & 0.001 & 0.823 \\
\hline \multicolumn{4}{|c|}{ lower secondary school enrolment: total expenditure } \\
\hline$x^{2}$-statistic $p$-value & 0.000 & 0.000 & 0.022 \\
\hline F-statistic $p$-value & 0.000 & 0.000 & 0.020 \\
\hline Hausman $x 2 p$-value & 0.000 & 0.000 & 0.013 \\
\hline \multicolumn{4}{|c|}{ lower secondary school enrolment: per capita expenditure } \\
\hline x2-statistic p-value & 0.005 & 0.011 & 0.091 \\
\hline F-statistic $p$-value & 0.002 & 0.007 & 0.088 \\
\hline Hausman $x 2 p$-value & 0.000 & 0.001 & 0.084 \\
\hline \multicolumn{4}{|c|}{ maternal mortality: total expenditure } \\
\hline$x^{2}$-statistic $p$-value & 0.688 & 0.122 & 0.000 \\
\hline F-statistic $p$-value & 0.693 & 0.121 & 0.000 \\
\hline Hausman $x 2 p$-value & 0.864 & 0.457 & 0.020 \\
\hline \multicolumn{4}{|c|}{ maternal mortality: per capita expenditure } \\
\hline$x^{2}$-statistic $p$-value & 0.000 & 0.020 & 0.000 \\
\hline F-statistic $p$-value & 0.000 & 0.019 & 0.000 \\
\hline Hausman $x 2 p$-value & 0.009 & 0.276 & 0.025 \\
\hline \multicolumn{4}{|c|}{ under 5 mortality: total expenditure } \\
\hline$x^{2}$-statistic $p$-value & 0.126 & 0.842 & 0.000 \\
\hline F-statistic $p$-value & 0.135 & 0.845 & 0.000 \\
\hline Hausman $x^{2} p$-value & 0.138 & 0.840 & 0.000 \\
\hline \multicolumn{4}{|c|}{ under 5 mortality: per capita expenditure } \\
\hline $\mathrm{x}^{2}$-statistic $\mathrm{p}$-value & 0.001 & 0.592 & 0.000 \\
\hline F-statistic $p$-value & 0.001 & 0.600 & 0.000 \\
\hline Hausman $x 2 p$-value & 0.002 & 0.596 & 0.000 \\
\hline \multicolumn{4}{|c|}{ total beds pc: total expenditure } \\
\hline $\mathrm{x}^{2}$-statistic $\mathrm{p}$-value & 0.000 & 0.000 & 0.000 \\
\hline F-statistic $p$-value & 0.000 & 0.000 & 0.000 \\
\hline Hausman $x^{2} p$-value & 0.001 & 0.000 & 0.004 \\
\hline \multicolumn{4}{|c|}{ total beds pc: per capita expenditure } \\
\hline $\mathrm{x}^{2}$-statistic $\mathrm{p}$-value & 0.000 & 0.000 & 0.000 \\
\hline F-statistic $p$-value & 0.000 & 0.000 & 0.000 \\
\hline Hausman $x^{2} p$-value & 0.000 & 0.000 & 0.009 \\
\hline \multicolumn{4}{|c|}{ BCGimmun: total expenditure } \\
\hline$x^{2}$-statistic $p$-value & 0.022 & 0.134 & 0.030 \\
\hline F-statistic $p$-value & 0.024 & 0.134 & 0.029 \\
\hline Hausman $x 2 p$-value & 0.032 & 0.130 & 0.042 \\
\hline \multicolumn{4}{|c|}{ BCGimmun: per capita expenditure } \\
\hline$x^{2}$-statistic p-value & 0.285 & 0.009 & 0.005 \\
\hline F-statistic p-value & 0.287 & 0.009 & 0.005 \\
\hline Hausman $x 2 p$-value & 0.307 & 0.007 & 0.012 \\
\hline \multicolumn{4}{|c|}{ DPT3immun: total expenditure } \\
\hline $\mathrm{x}^{2}$-statistic p-value & 0.000 & 0.003 & 0.000 \\
\hline F-statistic $p$-value & 0.000 & 0.004 & 0.000 \\
\hline Hausman $x 2 p$-value & 0.000 & 0.002 & 0.000 \\
\hline
\end{tabular}




\begin{tabular}{|c|c|c|c|}
\hline \multicolumn{4}{|c|}{ DPT3immun: per capita expenditure } \\
\hline $\mathrm{x}^{2}$-statistic $\mathrm{p}$-value & 0.000 & 0.001 & 0.000 \\
\hline$\hat{F}$-statistic $p$-value & 0.000 & 0.002 & 0.000 \\
\hline Hausman $x 2 p$-value & 0.001 & 0.000 & 0.000 \\
\hline \multicolumn{4}{|c|}{ OPV3immun: total expenditure } \\
\hline $\mathrm{x}^{2}$-statistic $\mathrm{p}$-value & 0.000 & 0.005 & 0.000 \\
\hline F-statistic $p$-value & 0.000 & 0.004 & 0.000 \\
\hline Hausman $x 2 p$-value & 0.000 & 0.003 & 0.000 \\
\hline \multicolumn{4}{|c|}{ OPV3immun: per capita expenditure } \\
\hline$x^{2}$-statistic $p$-value & 0.000 & 0.001 & 0.000 \\
\hline F-statistic $p$-value & 0.000 & 0.001 & 0.000 \\
\hline Hausman $x 2 p$-value & 0.001 & 0.000 & 0.000 \\
\hline \multicolumn{4}{|c|}{ Measles: total expenditure } \\
\hline $\mathrm{x}^{2}$-statistic $\mathrm{p}$-value & 0.000 & 0.001 & 0.039 \\
\hline F-statistic $p$-value & 0.000 & 0.001 & 0.040 \\
\hline Hausman $x 2 p$-value & 0.000 & 0.001 & 0.048 \\
\hline \multicolumn{4}{|c|}{ Measles: per capita expenditure } \\
\hline $\mathrm{x}^{2}$-statistic $\mathrm{p}$-value & 0.755 & 0.000 & 0.006 \\
\hline F-statistic $p$-value & 0.759 & 0.000 & 0.006 \\
\hline Hausman $\times 2 \mathrm{p}$-value & 0.762 & 0.000 & 0.012 \\
\hline \multicolumn{4}{|c|}{ FICimmun: total expenditure } \\
\hline $\mathrm{x}^{2}$-statistic $\mathrm{p}$-value & 0.001 & 0.101 & 0.000 \\
\hline F-statistic $p$-value & 0.000 & 0.102 & 0.000 \\
\hline Hausman $x 2 p$-value & 0.001 & 0.095 & 0.000 \\
\hline \multicolumn{4}{|c|}{ FICimmun: per capita expenditure } \\
\hline$x^{2}$-statistic $p$-value & 0.000 & 0.013 & 0.000 \\
\hline F-statistic $p$-value & 0.000 & 0.013 & 0.000 \\
\hline Hausman $x^{2} p$-value & 0.000 & 0.008 & 0.000 \\
\hline \multicolumn{4}{|c|}{ underweight5: total expenditure } \\
\hline x2-statistic $p$-value & 0.499 & 0.982 & 0.151 \\
\hline F-statistic $p$-value & 0.505 & 0.983 & 0.154 \\
\hline Hausman $x 2$-value & 0.509 & 0.981 & 0.078 \\
\hline \multicolumn{4}{|c|}{ underweight5: per capita expenditure } \\
\hline $\mathrm{x}^{2}$-statistic $\mathrm{p}$-value & 0.097 & 0.554 & 0.102 \\
\hline F-statistic $p$-value & 0.107 & 0.561 & 0.101 \\
\hline Hausman $x^{2} p$-value & 0.041 & 0.533 & 0.059 \\
\hline \multicolumn{4}{|c|}{ HC_Staff: total expenditure } \\
\hline $\mathrm{x}^{2}$-statistic $\mathrm{p}$-value & 0.033 & 0.000 & 0.000 \\
\hline F-statistic $p$-value & 0.027 & 0.000 & 0.000 \\
\hline Hausman $x^{2} p$-value & 0.001 & 0.000 & 0.000 \\
\hline \multicolumn{4}{|c|}{ HC_Staff: per capita expenditure } \\
\hline $\mathrm{x}^{2}$-statistic $\mathrm{p}$-value & 0.000 & 0.001 & 0.000 \\
\hline$\hat{F}$-statistic $p$-value & 0.000 & 0.000 & 0.000 \\
\hline Hausman $x^{2} p$-value & 0.000 & 0.000 & 0.000 \\
\hline \multicolumn{4}{|c|}{ Hosp_OPDStaffpc:total expenditure } \\
\hline$x^{2}$-statistic $p$-value & 0.002 & 0.000 & 0.021 \\
\hline F-statistic $p$-value & 0.002 & 0.000 & 0.024 \\
\hline Hausman $x 2 p$-value & 0.018 & 0.001 & 0.111 \\
\hline \multicolumn{4}{|c|}{ Hosp_OPDStaffpc: per capita expenditure } \\
\hline$x^{2}$-statistic $p$-value & 0.001 & 0.002 & 0.070 \\
\hline F-statistic $p$-value & 0.001 & 0.003 & 0.073 \\
\hline Hausman $x 2 p$-value & 0.006 & 0.011 & 0.208 \\
\hline
\end{tabular}


Appendix B: Fractionalization and central government expenditure

Table B 1: Fractionalization and education expenditure, GLS estimates

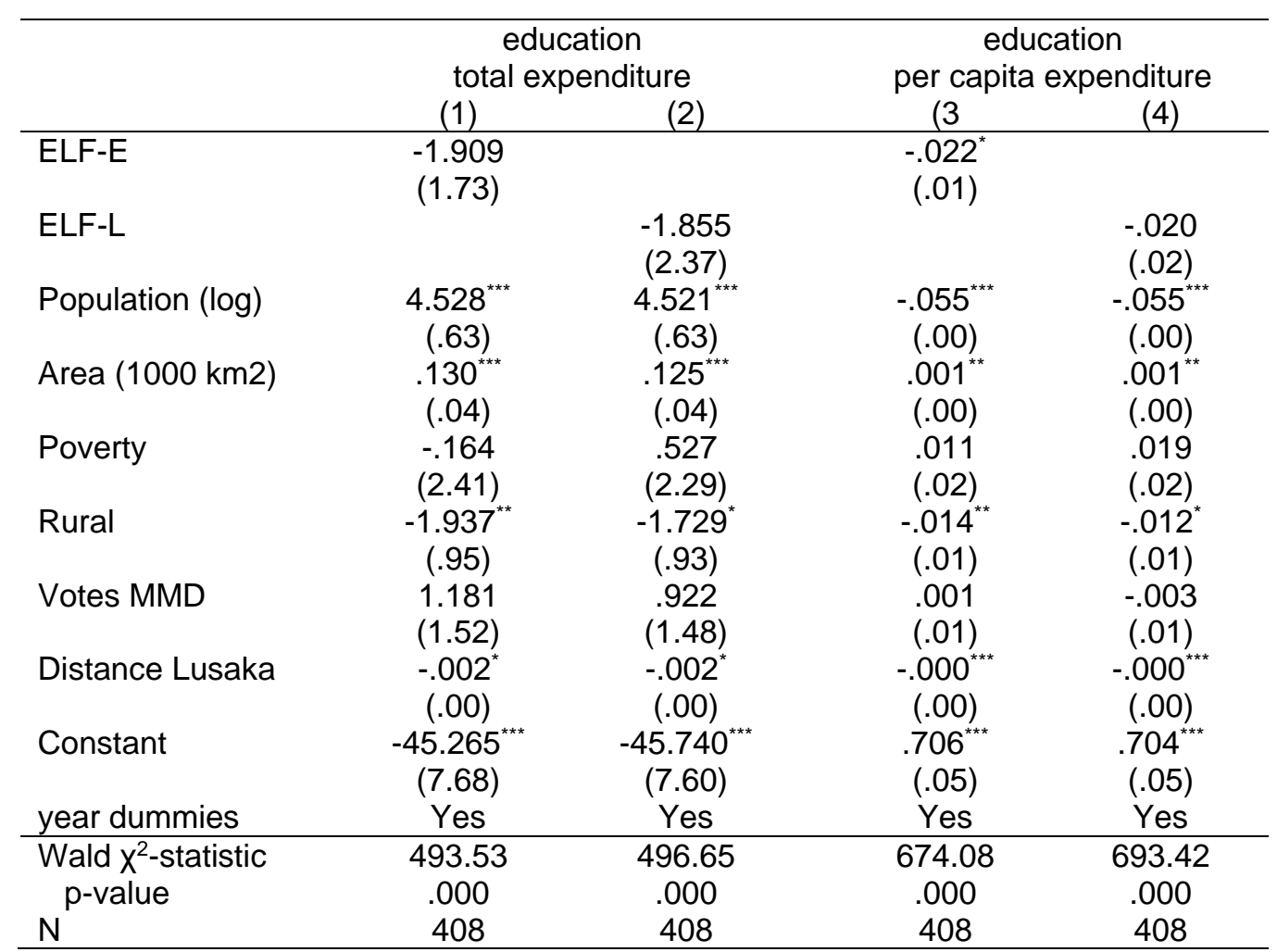

$\mathrm{AR}(1)$ autocorrelation consistent standard errors in parentheses;

${ }^{*} p<0.10,{ }^{* *} p<0.05,{ }^{* * *} p<0.01$. 
Table B 2: Fractionalization and district education board expenditure, GLS estimates

\begin{tabular}{|c|c|c|c|c|}
\hline & \multicolumn{2}{|c|}{$\begin{array}{l}\text { district education board } \\
\text { total expenditure }\end{array}$} & \multicolumn{2}{|c|}{$\begin{array}{l}\text { district education board } \\
\text { per capita expenditure }\end{array}$} \\
\hline & (1) & (2) & (3 & \\
\hline ELF-E & $\begin{array}{l}-.920^{* *} \\
(.42)\end{array}$ & & $\begin{array}{l}-.004^{*} \\
(.00)\end{array}$ & \\
\hline ELF-L & & $\begin{array}{c}-1.413^{* *} \\
(.60)\end{array}$ & & $\begin{array}{l}-.006^{* \star} \\
(.00)\end{array}$ \\
\hline Population (log) & $\begin{array}{l}.627^{\star \star \star} \\
(.15)\end{array}$ & $\begin{array}{l}.656^{*+*} \\
(.16)\end{array}$ & $\begin{array}{l}-.003^{\star \star \star \star} \\
(.00)\end{array}$ & $\begin{array}{l}-.003^{* \star \star *} \\
(.00)\end{array}$ \\
\hline Area $(1000 \mathrm{~km} 2)$ & $\begin{array}{l}-.009 \\
(.01)\end{array}$ & $\begin{array}{l}-.010 \\
(.01)\end{array}$ & $\begin{array}{l}-.000 \\
(.00)\end{array}$ & $\begin{array}{l}-.000 \\
(.00)\end{array}$ \\
\hline Poverty & $\begin{array}{l}.103 \\
(.58)\end{array}$ & $\begin{array}{l}.427 \\
(.58)\end{array}$ & $\begin{array}{l}.002 \\
(.00)\end{array}$ & $\begin{array}{l}.004 \\
(.00)\end{array}$ \\
\hline Rural & $\begin{array}{l}.281 \\
(.23)\end{array}$ & $\begin{array}{l}.402^{*} \\
(.24)\end{array}$ & $\begin{array}{l}.000 \\
(.00)\end{array}$ & $\begin{array}{l}.001 \\
(.00)\end{array}$ \\
\hline Votes MMD & $\begin{array}{l}.668^{*} \\
(.39)\end{array}$ & $\begin{array}{l}.578 \\
(.39)\end{array}$ & $\begin{array}{l}.003 \\
(.00)\end{array}$ & $\begin{array}{l}.002 \\
(.00)\end{array}$ \\
\hline Distance Lusaka & $\begin{array}{l}-.001^{* *} \\
(.00)\end{array}$ & $\begin{array}{l}-.001^{* *} \\
(.00)\end{array}$ & $\begin{array}{l}-.000^{* * *} \\
(.00)\end{array}$ & $\begin{array}{l}-.000^{* * *} \\
(.00)\end{array}$ \\
\hline Constant & $\begin{array}{l}-6.833^{* \star *+} \\
(1.86)\end{array}$ & $\begin{array}{l}-7.217^{\star \star \star \alpha *} \\
(1.92)\end{array}$ & $\begin{array}{l}.039^{* \star *} \\
(.01)\end{array}$ & $\begin{array}{l}.037^{* \star * *} \\
(.01)\end{array}$ \\
\hline year dummies & Yes & Yes & Yes & Yes \\
\hline $\begin{array}{l}\text { Wald } x^{2} \text {-statistic } \\
\text { p-value } \\
N\end{array}$ & $\begin{array}{l}96.05 \\
.000 \\
408\end{array}$ & $\begin{array}{l}99.10 \\
.000 \\
408\end{array}$ & $\begin{array}{c}218.37 \\
.000 \\
408\end{array}$ & $\begin{array}{c}219.41 \\
.000 \\
408\end{array}$ \\
\hline
\end{tabular}

$\mathrm{AR}(1)$ autocorrelation consistent standard errors in parentheses;

${ }^{*} p<0.10,{ }^{* *} p<0.05,{ }^{* \star *} p<0.01$. 
Table B 3: Fractionalization and basic school expenditure, GLS estimates

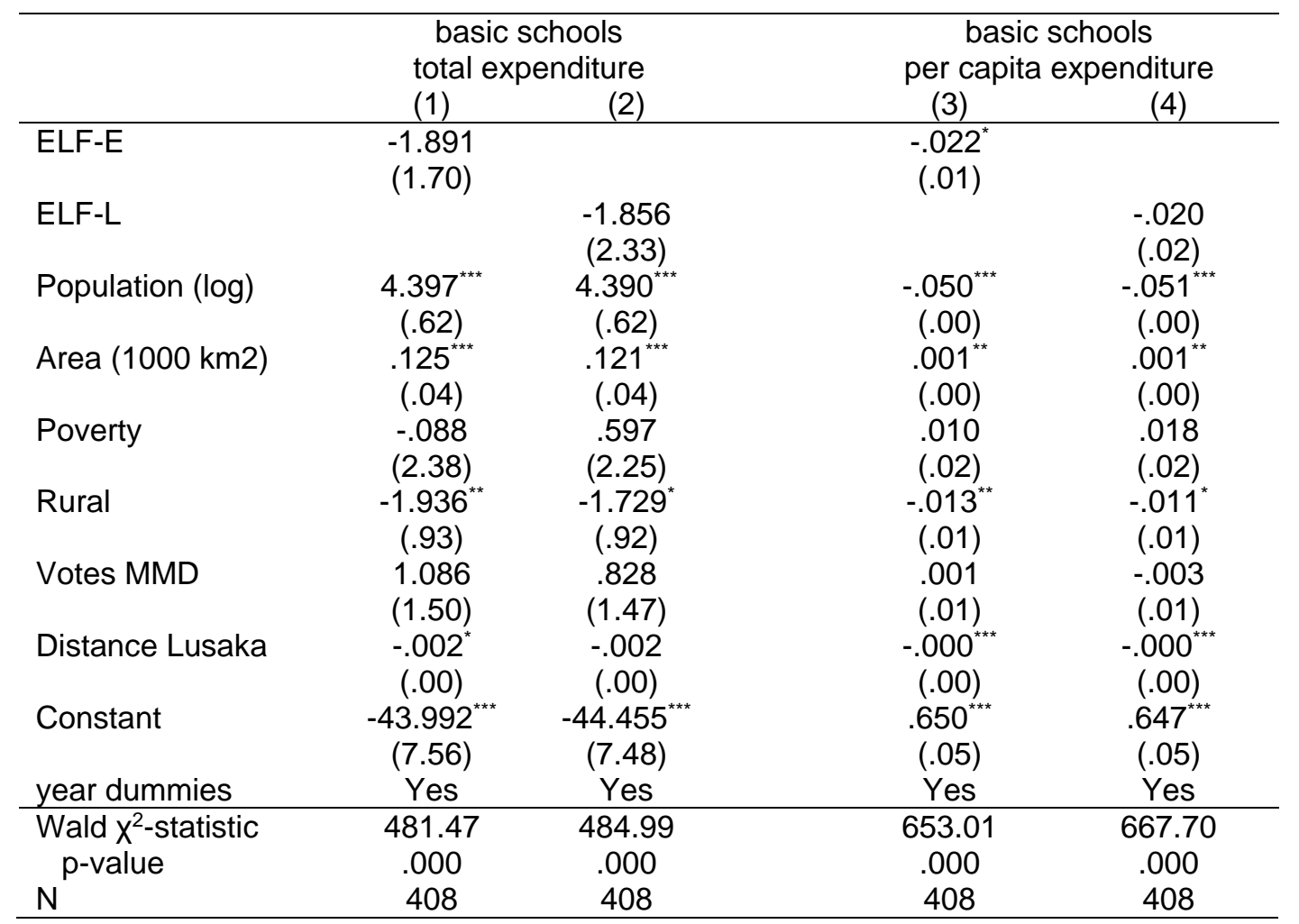

$\mathrm{AR}(1)$ autocorrelation consistent standard errors in parentheses;

${ }^{*} p<0.10,{ }^{* *} p<0.05,{ }^{* \star *} p<0.01$. 
Table B 4: Fractionalization and expenditure on grants to basic schools, GLS estimates

\begin{tabular}{|c|c|c|c|c|}
\hline & \multicolumn{2}{|c|}{$\begin{array}{l}\text { grants to basic schools } \\
\text { total expenditure }\end{array}$} & \multicolumn{2}{|c|}{$\begin{array}{l}\text { grants to basic schools per } \\
\text { capita expenditure }\end{array}$} \\
\hline & $(1)$ & $(2)$ & (3) & $(4)$ \\
\hline ELF-E & $\begin{array}{l}.014 \\
(.11)\end{array}$ & & $\begin{array}{l}-.002 \\
(.01)\end{array}$ & \\
\hline ELF-L & & $\begin{array}{l}.054 \\
(.15)\end{array}$ & & $\begin{array}{l}-.003 \\
(.01)\end{array}$ \\
\hline Political (national) & $\begin{array}{l}.272^{\star \star \star} \\
(.04)\end{array}$ & $\begin{array}{l}.270^{\star \star \star *} \\
(.04)\end{array}$ & $\begin{array}{l}-.023^{\star \star \star} \\
(.00)\end{array}$ & $\begin{array}{l}-.023^{\star \star \star} \\
(.00)\end{array}$ \\
\hline Area $(1000 \mathrm{~km} 2)$ & $\begin{array}{l}.008^{* \star \star} \\
(.00)\end{array}$ & $\begin{array}{l}.008^{\star \star \star *} \\
(.00)\end{array}$ & $\begin{array}{l}-.000 \\
(.00)\end{array}$ & $\begin{array}{l}-.000 \\
(.00)\end{array}$ \\
\hline Poverty & $\begin{array}{l}.262^{*} \\
(.15)\end{array}$ & $\begin{array}{l}.257^{*} \\
(.14)\end{array}$ & $\begin{array}{l}.018^{*} \\
(.01)\end{array}$ & $\begin{array}{l}.018^{\star *} \\
(.01)\end{array}$ \\
\hline Rural & $\begin{array}{l}-.000 \\
(.06)\end{array}$ & $\begin{array}{l}-.003 \\
(.06)\end{array}$ & $\begin{array}{l}-.003 \\
(.00)\end{array}$ & $\begin{array}{l}-.003 \\
(.00)\end{array}$ \\
\hline Votes MMD & $\begin{array}{l}-.136 \\
(.12)\end{array}$ & $\begin{array}{l}-.139 \\
(.11)\end{array}$ & $\begin{array}{l}-.005 \\
(.01)\end{array}$ & $\begin{array}{l}-.005 \\
(.01)\end{array}$ \\
\hline Distance Lusaka & $\begin{array}{l}-.000 \\
(.00)\end{array}$ & $\begin{array}{l}-.000 \\
(.00)\end{array}$ & $\begin{array}{l}-.000 \\
(.00)\end{array}$ & $\begin{array}{l}-.000 \\
(.00)\end{array}$ \\
\hline Constant & $\begin{array}{c}-3.222^{\star \star \star} \\
(.49)\end{array}$ & $\begin{array}{l}-3.206^{\star \star \star} \\
(.49)\end{array}$ & $\begin{array}{l}.265^{\star \star *} \\
(.03)\end{array}$ & $\begin{array}{l}.264^{\star \star \star *} \\
(.03)\end{array}$ \\
\hline year dummies & Yes & Yes & Yes & Yes \\
\hline Wald $\mathrm{X}^{2}$-statistic & 3163.25 & 3164.77 & 1488.83 & 1489.02 \\
\hline$N^{p \text {-value }}$ & $\begin{array}{l}.000 \\
406\end{array}$ & $\begin{array}{l}.000 \\
406\end{array}$ & $\begin{array}{l}.000 \\
406\end{array}$ & $\begin{array}{l}.000 \\
406\end{array}$ \\
\hline
\end{tabular}

$\mathrm{AR}(1)$ autocorrelation consistent standard errors in parentheses;

${ }^{*} p<0.10,{ }^{* *} p<0.05,{ }^{* \star *} p<0.01$. 
Table B 5: Fractionalization and expenditure on teacher salaries, GLS estimates

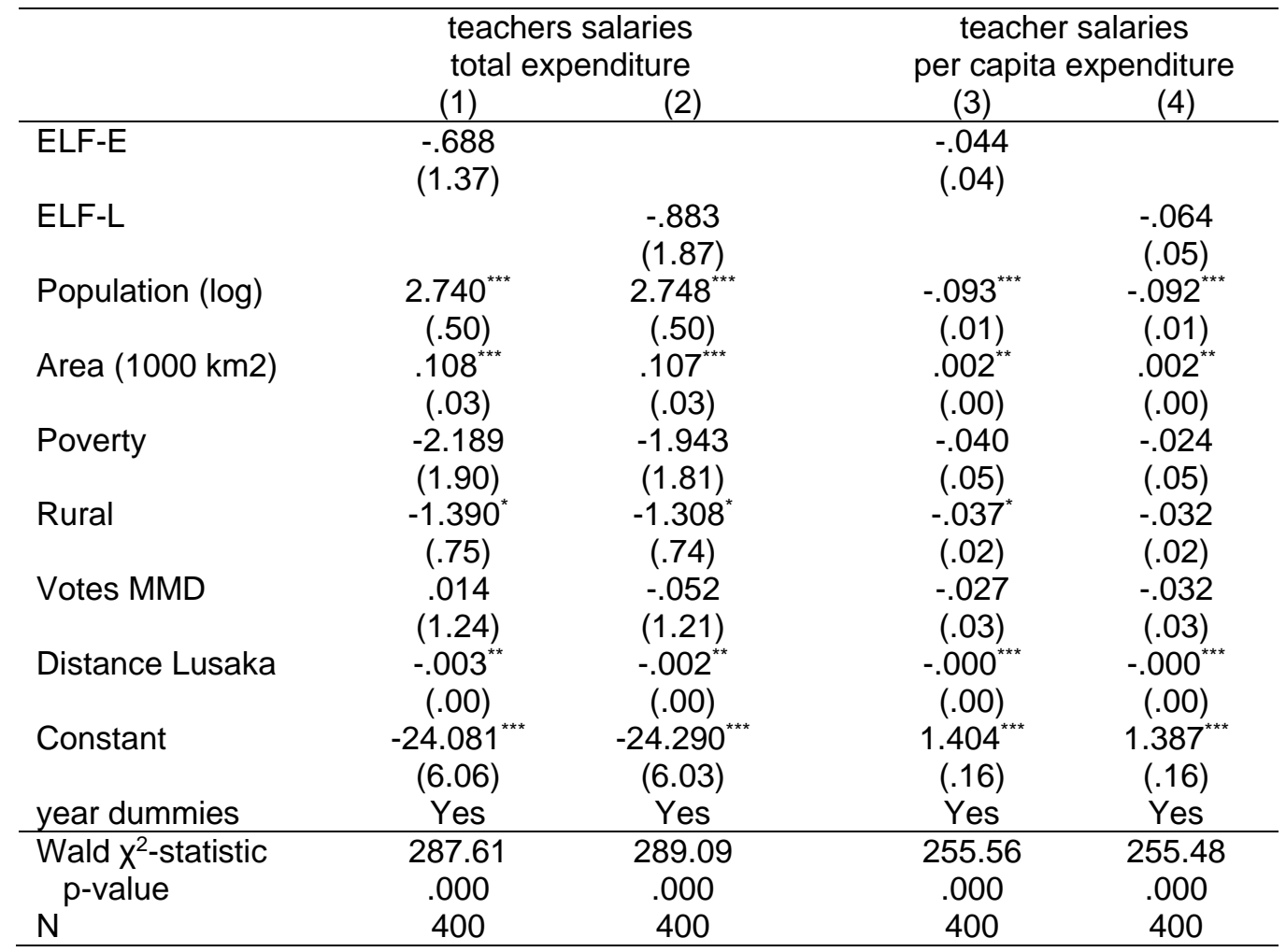

$\mathrm{AR}(1)$ autocorrelation consistent standard errors in parentheses;

${ }^{*} p<0.10,{ }^{* *} p<0.05,{ }^{* \star *} p<0.01$. 
Table B 6: Fractionalization and health expenditure, GLS estimates

\begin{tabular}{|c|c|c|c|c|}
\hline \multirow{3}{*}{ ELF-E } & \multicolumn{2}{|c|}{$\begin{array}{c}\text { health } \\
\text { total expenditure }\end{array}$} & \multicolumn{2}{|c|}{$\begin{array}{c}\text { health } \\
\text { per capita expenditure }\end{array}$} \\
\hline & (1) & $(2)$ & (3) & $(4)$ \\
\hline & $\begin{array}{l}-3.116^{\star \star} \\
(1.54)\end{array}$ & & $\begin{array}{l}-.027 \\
(.03)\end{array}$ & \\
\hline ELF-L & & $\begin{array}{c}-3.533^{*} \\
(2.07)\end{array}$ & & $\begin{array}{l}-.030 \\
(.05)\end{array}$ \\
\hline Population (log) & $\begin{array}{l}2.532^{\star \star \star} \\
(.56)\end{array}$ & $\begin{array}{l}2.576^{\star \star \star} \\
(.55)\end{array}$ & $\begin{array}{l}-.007 \\
(.01)\end{array}$ & $\begin{array}{l}-.006 \\
(.01)\end{array}$ \\
\hline Area $(1000 \mathrm{~km} 2)$ & $\begin{array}{l}.012 \\
(.04)\end{array}$ & $\begin{array}{l}.007 \\
(.04)\end{array}$ & $\begin{array}{r}-.000 \\
(.00)\end{array}$ & $\begin{array}{l}-.000 \\
(.00)\end{array}$ \\
\hline Poverty & $\begin{array}{l}3.866^{*} \\
(2.16)\end{array}$ & $\begin{array}{l}4.954^{\star \star} \\
(2.00)\end{array}$ & $\begin{array}{l}.023 \\
(.04)\end{array}$ & $\begin{array}{l}.034 \\
(.05)\end{array}$ \\
\hline Rural & $\begin{array}{c}-6.771^{\star \star \star} \\
(.85)\end{array}$ & $\begin{array}{c}-6.380^{\star \star \star} \\
(.81)\end{array}$ & $\begin{array}{c}-.034^{*} \\
(.02)\end{array}$ & $\begin{array}{l}-.031 \\
(.02)\end{array}$ \\
\hline Votes MMD & $\begin{array}{l}-.163 \\
(1.16)\end{array}$ & $\begin{array}{l}-.528 \\
(1.14)\end{array}$ & $\begin{array}{l}.010 \\
(.01)\end{array}$ & $\begin{array}{l}.010 \\
(.01)\end{array}$ \\
\hline Distance Lusaka & $\begin{array}{c}-.003^{* \star \star} \\
(.00)\end{array}$ & $\begin{array}{c}-.003^{* \star \star} \\
(.00)\end{array}$ & $\begin{array}{r}-.000 \\
(.00)\end{array}$ & $\begin{array}{l}-.000 \\
(.00)\end{array}$ \\
\hline Constant & $\begin{array}{c}-22.732^{\star \star \star} \\
(6.82)\end{array}$ & $\begin{array}{c}-23.972^{\star \star \star} \\
(6.59)\end{array}$ & $\begin{array}{l}.127 \\
(.14)\end{array}$ & $\begin{array}{l}.111 \\
(.15)\end{array}$ \\
\hline year dummies & Yes & Yes & Yes & Yes \\
\hline Wald $x^{2}$-statistic & 317.47 & 329.50 & 117.88 & 114.34 \\
\hline p-value & .000 & .000 & .000 & .000 \\
\hline$N$ & 408 & 408 & 408 & 408 \\
\hline
\end{tabular}

$\mathrm{AR}(1)$ autocorrelation consistent standard errors in parentheses;

${ }^{*} p<0.10,{ }^{* *} p<0.05,{ }^{* \star *} p<0.01$. 
Table B 7: Fractionalization and expenditure on health service delivery, GLS estimates

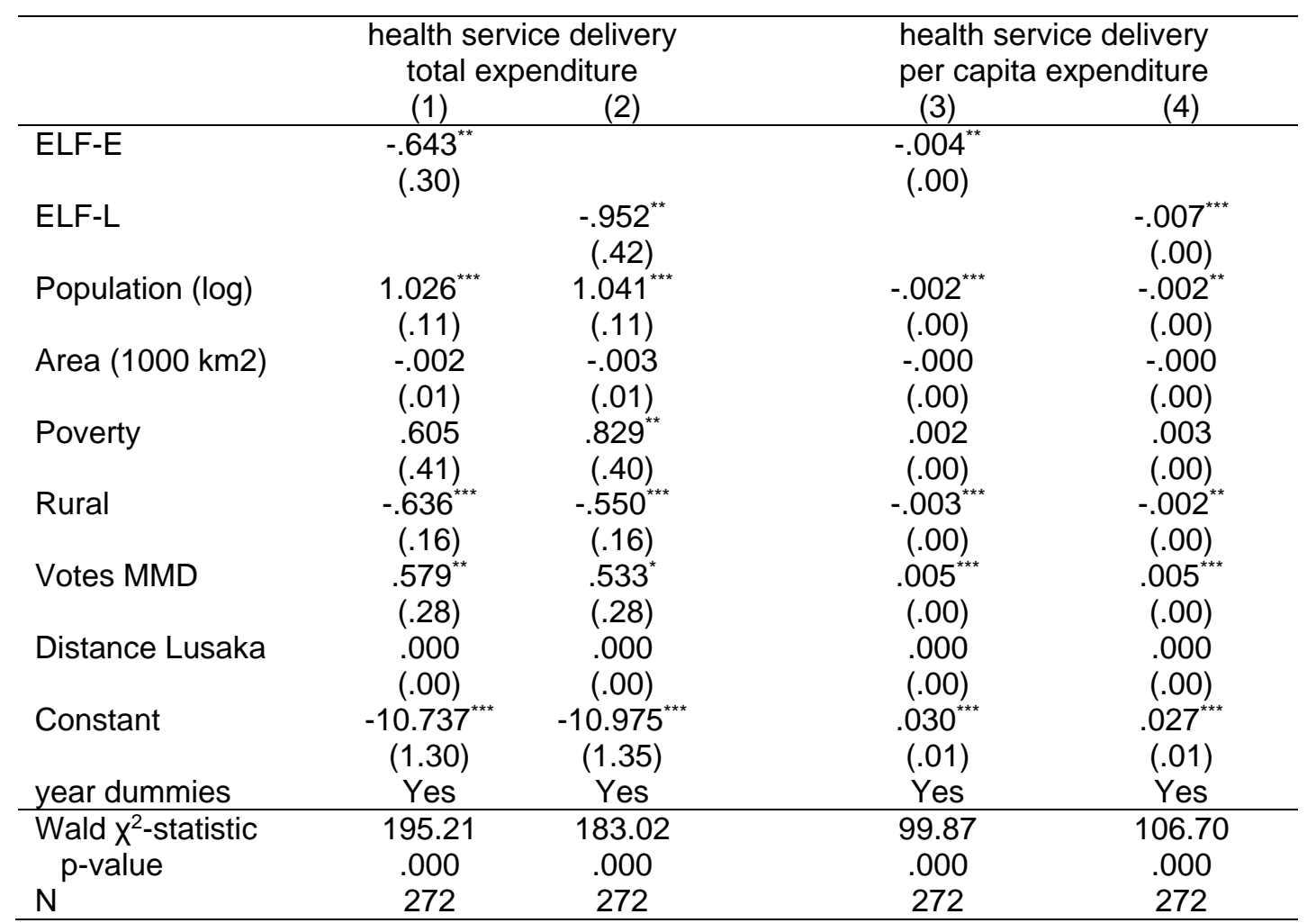

$\mathrm{AR}(1)$ autocorrelation consistent standard errors in parentheses;

${ }^{*} p<0.10,{ }^{* *} p<0.05,{ }^{* * *} p<0.01$. 


\section{Appendix C: Fractionalization and budget estimates}

Table C6: Panel GLS regression results for health and education budget estimates

\begin{tabular}{|c|c|c|}
\hline \multirow[b]{2}{*}{ Dependent variable } & \multicolumn{2}{|c|}{ Main explanatory variable } \\
\hline & ELF-E & ELF-L \\
\hline Education total allocation & - & - \\
\hline Education per capita allocation & negative $^{*}$ & - \\
\hline DEB allocation & negative ${ }^{\star *}$ & negative $^{\star *}$ \\
\hline DEB allocation per capita & negative ${ }^{\star *}$ & negative ${ }^{\star *}$ \\
\hline Basic schools allocation & - & - \\
\hline Basic schools allocation per capita & negative* & - \\
\hline Grants to basic schools & - & - \\
\hline $\begin{array}{l}\text { Grants to basic schools per capita in relevant age } \\
\text { group }\end{array}$ & - & - \\
\hline Teachers' salaries & - & - \\
\hline Teachers' salaries per capita in relevant age group & - & - \\
\hline Health allocations & negative $^{*}$ & - \\
\hline Per capita health allocation & - & - \\
\hline Health service allocations & negative $^{\star \star \star}$ & negative $^{\star \star \star}$ \\
\hline Per capita health service allocations & negative $^{\star *}$ & negative $^{* *}$ \\
\hline
\end{tabular}

coefficient insignificant at conventional levels; ${ }^{*} .10$ percent significance level; ${ }^{* *} .5$ percent significance level; ${ }^{* * *}$. 1-percent significance level. 
Table C 1: Panel GLS regression results for health and education budget execution rates

\begin{tabular}{|c|c|c|c|c|c|c|c|}
\hline & $\begin{array}{c}\text { total } \\
\text { education }\end{array}$ & DEB & basic schools & $\begin{array}{c}\text { grants basic } \\
\text { schools }\end{array}$ & $\begin{array}{l}\text { teachers' } \\
\text { salaries }\end{array}$ & $\begin{array}{c}\text { total } \\
\text { health }\end{array}$ & $\begin{array}{c}\text { health service } \\
\text { delivery }\end{array}$ \\
\hline \multirow[t]{2}{*}{ ELF-E } & .003 & -.024 & .004 & .032 & -.004 & -.000 & -.063 \\
\hline & $(.02)$ & $(.03)$ & $(.02)$ & $(.11)$ & $(.01)$ & $(.05)$ & $(.07)$ \\
\hline \multirow{2}{*}{ Population (log) } & $.010^{*}$ & .008 & $.012^{* *}$ & $.147^{\star \star \star}$ & .003 & $.064^{* \star *}$ & .034 \\
\hline & $(.01)$ & $(.01)$ & $(.01)$ & $(.04)$ & $(.00)$ & $(.02)$ & $(.02)$ \\
\hline \multirow[t]{2}{*}{ Area (1000 km2) } & -.000 & -.000 & -.000 & -.000 & .000 & .000 & .000 \\
\hline & $(.00)$ & $(.00)$ & $(.00)$ & $(.00)$ & $(.00)$ & $(.00)$ & $(.00)$ \\
\hline Poverty & -.010 & -.017 & -.010 & .119 & -.021 & .013 & .036 \\
\hline \multirow[t]{2}{*}{ Rural } & .006 & -.015 & .009 & $.165^{\star \star \star}$ & .002 & $-.089^{\star \star \star}$ & -.040 \\
\hline & $(.01)$ & $(.01)$ & $(.01)$ & $(.06)$ & $(.01)$ & $(.02)$ & $(.04)$ \\
\hline \multirow[t]{2}{*}{ Votes MMD } & $.036^{* *}$ & $.073^{* *}$ & $.037^{* *}$ & .111 & .005 & .027 & $.194^{\star \star \star}$ \\
\hline & $(.02)$ & $(.03)$ & $(.02)$ & $(.12)$ & $(.01)$ & $(.05)$ & $(.07)$ \\
\hline \multirow[t]{2}{*}{ Distance Lusaka } & .000 & $-.000^{\star \star \star}$ & .000 & .000 & $.000^{* *}$ & .000 & .000 \\
\hline & $(.00)$ & $(.00)$ & $(.00)$ & $(.00)$ & $(.00)$ & $(.00)$ & $(.00)$ \\
\hline \multirow[t]{2}{*}{2005} & .003 & $.072^{\star \star \star}$ & -.003 & $.137^{* *}$ & .008 & $-.318^{\star * *}$ & .000 \\
\hline & $(.01)$ & $(.02)$ & $(.01)$ & $(.06)$ & $(.01)$ & $(.02)$ & $()$. \\
\hline 2006 & -.007 & $.073^{\star \star \star}$ & -.011 & $.127^{* *}$ & $-.016^{* *}$ & $.275^{\star \star \star}$ & $.326^{\star \star \star}$ \\
\hline \multirow[t]{2}{*}{2007} & -.014 & $.065^{\star \star \star}$ & $-.019^{\star}$ & $-.329^{\star \star \star}$ & .008 & $.270^{\star \star \star *}$ & -.047 \\
\hline & $(.01)$ & $(.02)$ & $(.01)$ & $(.07)$ & $(.01)$ & $(.03)$ & $(.03)$ \\
\hline \multirow[t]{2}{*}{2008} & $.173^{\star \star \star}$ & $-.235^{\star \star \star}$ & $.224^{\star \star \star}$ & $3.072^{\star \star \star}$ & .009 & $.416^{\star \star \star}$ & $.188^{\star \star \star}$ \\
\hline & $(.01)$ & $(.02)$ & $(.01)$ & $(.07)$ & $(.01)$ & $(.03)$ & $(.03)$ \\
\hline \multirow[t]{2}{*}{2009} & $.020^{\star *}$ & $-.299^{\star \star \star}$ & $.028^{* *}$ & $.117^{*}$ & .009 & $.283^{\star \star \star}$ & .000 \\
\hline & $(.01)$ & $(.02)$ & $(.01)$ & $(.07)$ & $(.01)$ & $(.03)$ & $()$. \\
\hline \multirow{2}{*}{ Constant } & $.837^{\star \star \star}$ & $.845^{\star \star \star}$ & $.803^{\star \star \star}$ & $-1.165^{\star \star}$ & $.953^{\star \star \star}$ & -.199 & .228 \\
\hline & $(.07)$ & $(.12)$ & $(.08)$ & $(.51)$ & $(.05)$ & $(.20)$ & $(.30)$ \\
\hline $\mathrm{N}$ & 408 & 408 & 408 & 406 & 400 & 408 & 272 \\
\hline
\end{tabular}

Panel-robust (first-order autocorrelation) standard errors in parentheses

${ }^{*} p<0.10,{ }^{* \star} p<0.05,{ }^{\star * \star} p<0.01$. 
Appendix D: Fractionalization and education and health outcomes

Table D 1: Overview regressions results ELF-E and outcomes—per capita expenditure

\begin{tabular}{|c|c|c|c|c|c|c|}
\hline \multirow{2}{*}{$\begin{array}{c}\text { Method } \\
\text { Dependent variable }\end{array}$} & OLS & $2 S L S^{a}$ & $2 \mathrm{SLS}^{b}$ & $2 S L S^{c}$ & $\mathrm{GMM}^{c}$ & $\operatorname{LIML}^{c}$ \\
\hline & \multicolumn{6}{|c|}{ Coefficient on ELF-E } \\
\hline Prim. school enrolment & $.289^{\star \star \star}$ & $.306^{* \star \star}$ & $.280^{\star \star \star}$ & $.305^{\star \star \star}$ & $.299^{\star \star \star}$ & $.305^{\star \star \star}$ \\
\hline Lower sec. enrolment & $.074^{*}$ & $.091^{* *}$ & $.144^{*}$ & $.093^{* *}$ & $.087^{\star \star}$ & $.093^{* *}$ \\
\hline No. schools 2008 & $.005^{\star \star \star}$ & $.006^{\star \star \star}$ & .026 & $.006^{\star \star \star}$ & $.006^{\star \star \star}$ & $.007^{\star \star \star}$ \\
\hline No. teachers 2008 & 6.721 & .475 & 51.895 & 2.081 & 4.033 & .826 \\
\hline No. basic schools 2009 & -1.290 & -60.753 & 261.131 & -57.219 & $-69.002^{*}$ & -61.785 \\
\hline Teacher pupil ratio 2008 & .002 & .001 & .005 & .002 & .002 & .002 \\
\hline Basic school t/p ratio '09 & $322.728^{*}$ & 263.745 & 881.182 & 283.022 & 270.103 & 262.233 \\
\hline Maternal mortality & 82.851 & 256.047 & 21.782 & 83.583 & -50.022 & 83.589 \\
\hline Under 5 mortality & -7.621 & -8.373 & -1.851 & -3.583 & -12.384 & -2.871 \\
\hline Total beds & $-1.515^{\star \star \star}$ & -.994 & $-1.312^{\star *}$ & $-1.227^{*}$ & $-1.682^{\star \star \star}$ & -1.194 \\
\hline BCG immunization & $.190^{\star \star \star}$ & .144 & $.215^{\star \star \star}$ & $.197^{\star \star \star}$ & $.220^{\star \star \star}$ & $.212^{* *}$ \\
\hline DPT3 immunization & $.238^{\star \star \star}$ & .168 & $.294^{\star \star \star}$ & $.261^{* \star *}$ & $.352^{* \star \star}$ & .335 \\
\hline OPV3 immunization & $.270^{\star \star \star}$ & .197 & $.331^{\star \star \star}$ & $.295^{\star \star \star}$ & $.340^{\star \star \star}$ & .370 \\
\hline Measles immunization & $.204^{\star \star \star}$ & .130 & $.227^{\star \star \star}$ & $.201^{\star \star \star}$ & $.210^{\star \star \star}$ & -.054 \\
\hline FIC immunization & $.361^{\star \star \star}$ & $.329^{\star \star \star}$ & $.399^{\star \star \star}$ & $.380^{\star \star \star}$ & $.426^{\star \star \star}$ & $.405^{\star \star \star}$ \\
\hline Underweight under 5 & $-12.807^{\star \star \star}$ & $-13.159^{* \star \star}$ & $-13.224^{\star \star \star}$ & $-13.206^{\star \star \star}$ & $-13.215^{\star \star \star}$ & $-13.207^{\star \star \star}$ \\
\hline Health Centre Staff p.c. & $2.665^{\star \star \star}$ & $3.338^{\star \star \star}$ & $3.174^{\star \star \star}$ & $3.217^{\star \star \star}$ & $3.086^{* * *}$ & $3.224^{\star \star \star}$ \\
\hline Hospital OPD Staff p.c. & $.299^{*}$ & $.348^{*}$ & $.322^{*}$ & $.335^{*}$ & $.293^{*}$ & $.336^{*}$ \\
\hline $\begin{array}{l}\text { * } p<0.10, \\
\text { Notes: values show estir } \\
\text { central government expe } \\
\text { using distance from distric } \\
\text { population and distance }\end{array}$ & $p<$ & $\begin{array}{l}\text { aka; }{ }^{c} \text { in } \\
\text { ital to } \mathrm{L}\end{array}$ & $\begin{array}{l}<0 \\
<r a c t i o n\end{array}$ & $\begin{array}{l}\text { for } \\
\text { ion inde } \\
\text { for cent } \\
\text { al goverr }\end{array}$ & $\begin{array}{l}\text { USt sta } \\
\text { ELF-E; }{ }^{a} \\
\text { governm }\end{array}$ & $\begin{array}{l}\text { ard errors } \\
\text { ruments fol } \\
\text { expenditure } \\
\text { rre using log }\end{array}$ \\
\hline
\end{tabular}


Table D 2: Overview regressions results ELF-L and outcomes-total expenditure

\begin{tabular}{|c|c|c|c|c|c|c|}
\hline Method & OLS & $2 S L S^{a}$ & $2 S^{2} S^{b}$ & $2 S L S^{c}$ & $\mathrm{GMM}^{\mathrm{c}}$ & LIML $^{c}$ \\
\hline Dependent variable & \multicolumn{6}{|c|}{ Coefficient on ELF-L } \\
\hline $\begin{array}{ll}\text { Primary } & \text { school } \\
\text { enrolment } & \end{array}$ & $.257^{\star \star \star}$ & $.340^{\star \star \star}$ & $.220^{\star \star \star}$ & $.331^{\star \star *}$ & $.322^{\star \star \star}$ & $.336^{\star \star \star}$ \\
\hline $\begin{array}{ll}\text { Lower } & \text { secondary } \\
\text { enrolment } & \end{array}$ & -.032 & .045 & $-.152^{\star}$ & .031 & .017 & .047 \\
\hline $\begin{array}{l}\text { Number of schools } \\
(2008)\end{array}$ & -3.935 & -42.088 & -11.700 & -38.936 & -38.789 & -39.924 \\
\hline $\begin{array}{l}\text { Number of teachers } \\
(2008)\end{array}$ & 114.195 & -100.180 & -255.915 & -116.335 & -139.595 & -119.629 \\
\hline $\begin{array}{l}\text { Number of basic } \\
\text { schools (2009) }\end{array}$ & 14.515 & -.108 & -7.661 & -.204 & -1.777 & -.240 \\
\hline $\begin{array}{l}\text { Teacher-pupil ratio } \\
(2008)\end{array}$ & -.000 & .003 & -.008 & .002 & .005 & .003 \\
\hline $\begin{array}{l}\text { Teacher-pupil ratio in } \\
\text { basic schools (2009) }\end{array}$ & .002 & .003 & -.003 & .003 & .004 & .004 \\
\hline Maternal mortality & -33.249 & -34.521 & -20.867 & -31.878 & -91.542 & -31.655 \\
\hline Under 5 mortality & -5.066 & -5.063 & -6.404 & -5.312 & -16.096 & -5.377 \\
\hline Total beds & $-1.390^{\star \star \star}$ & $-1.348^{* \star \star}$ & $-1.437^{\star \star}$ & $-1.364^{\star \star \star}$ & $-2.251^{\star \star \star}$ & $-1.352^{\star \star \star}$ \\
\hline $\begin{array}{l}\text { Health Centre Staff } \\
\text { p.c. }\end{array}$ & $2.165^{\star \star \star}$ & $2.219^{\star \star \star}$ & $2.020^{\star *}$ & $2.182^{\star \star \star}$ & $2.727^{\star \star \star}$ & 2.437 \\
\hline Hospital OPD Staff p.c. & -.063 & .003 & -.153 & -.038 & -.164 & -.023 \\
\hline BCG immunization & $.233^{\star \star \star}$ & $.231^{\star \star \star}$ & $.229^{\star \star \star}$ & $.231^{\star \star \star}$ & $.227^{\star \star \star}$ & $.231^{* \star *}$ \\
\hline DPT3 immunization & $.307^{\star \star \star}$ & $.303^{\star \star \star}$ & $.295^{\star \star \star}$ & $.301^{\star \star \star}$ & $.282^{\star \star \star}$ & $.301^{\star \star \star}$ \\
\hline OPV3 immunization & $.321^{\star \star \star}$ & $.317^{\star \star \star}$ & $.308^{\star \star \star}$ & $.315^{\star \star \star}$ & $.291^{\star \star \star}$ & $.314^{\star \star \star}$ \\
\hline Measles immunization & $.212^{\star \star \star}$ & $.208^{\star \star \star}$ & $.208^{\star \star \star}$ & $.208^{\star \star \star}$ & $.206^{\star \star \star}$ & $.208^{\star \star \star}$ \\
\hline FIC immunization & $.366^{\star \star \star}$ & $.365^{\star \star \star}$ & $.357^{\star \star \star}$ & $.363^{* \star *}$ & $.365^{\star \star \star}$ & $.362^{\star \star \star}$ \\
\hline Underweight under 5 & $-11.228^{\star \star \star}$ & $-11.237^{\star \star \star}$ & $-11.078^{\star \star \star}$ & $-11.208^{* \star \star}$ & $-11.923^{* \star \star}$ & $-11.204^{\star \star \star}$ \\
\hline
\end{tabular}


Table D 3: Total Expenditure-primary school enrolment

\begin{tabular}{|c|c|c|c|c|c|c|}
\hline Method & OLS & $2 S L S^{a}$ & $2 S L S^{b}$ & $2 S L S^{c}$ & $\mathrm{GMM}^{c}$ & $\operatorname{LIML}^{c}$ \\
\hline ELF-E & $.261^{\star * \star}$ & $.305^{\star \star \star}$ & $.249^{\star \star \star}$ & $.300^{\star * \star}$ & $.304^{\star * \star}$ & $.303^{* \star \star}$ \\
\hline Area (1000 km2) & $.003^{* *}$ & $.008^{\star \star *}$ & .001 & $.007^{\star \star \star}$ & $.008^{\star \star \star}$ & $.008^{\star \star \star}$ \\
\hline Poverty & $-.198^{\star \star \star}$ & $-.204^{\star \star}$ & $-.196^{\star \star \star}$ & $-.203^{\star \star}$ & $-.206^{\star \star}$ & $-.203^{\star \star}$ \\
\hline Expenditure & -.002 & $-.032^{\star \star \star}$ & .006 & $-.029^{\star \star \star}$ & $-.028^{\star \star \star}$ & $-.030^{\star \star \star}$ \\
\hline Rural & $.087^{\star \star \star}$ & -.040 & $.121^{\star \star}$ & -.027 & -.031 & -.034 \\
\hline 2005 & $.329^{\star \star *}$ & $.348^{\star \star \star}$ & $.324^{\star \star \star}$ & $.346^{\star \star \star}$ & $.345^{\star \star \star}$ & $.347^{\star \star \star}$ \\
\hline 2006 & $.317^{\star \star \star}$ & $.435^{\star \star \star}$ & $.285^{\star \star \star}$ & $.423^{\star \star \star}$ & $.423^{\star \star \star}$ & $.429^{\star \star \star}$ \\
\hline 2007 & $.443^{\star \star *}$ & $.555^{\star \star \star}$ & $.414^{\star \star \star}$ & $.544^{\star \star \star}$ & $.537^{\star \star \star}$ & $.550^{\star \star \star}$ \\
\hline 2008 & $.418^{\star \star \star}$ & $.697^{\star \star \star}$ & $.343^{\star \star \star}$ & $.669^{\star \star \star}$ & $.663^{\star \star \star}$ & $.684^{\star \star \star}$ \\
\hline 2009 & $.420^{\star \star *}$ & $.768^{\star \star \star}$ & $.326^{\star \star}$ & $.732^{\star \star \star}$ & $.718^{\star \star \star}$ & $.752^{\star \star \star}$ \\
\hline Constant & $.888^{* \star *}$ & $1.093^{\star \star \star}$ & $.833^{* \star \star}$ & $1.071^{\star \star \star}$ & $1.074^{\star \star \star}$ & $1.083^{\star \star \star}$ \\
\hline R-squared & .445 & .173 & .426 & .226 & .228 & .198 \\
\hline F-statistic & $44.67^{\star \star \star}$ & & & & & \\
\hline Wald $x^{2}$ & & $332.80^{\star \star \star}$ & $439.38^{\star \star \star}$ & $350.66^{\star \star \star}$ & $346.26^{\star \star *}$ & $340.61^{\star * \star}$ \\
\hline Observations & 408 & 408 & 408 & 408 & 408 & 408 \\
\hline
\end{tabular}

Notes: values show estimated coefficient for ELF-E fractionalization index; a instruments for central government expenditure using log population; ${ }^{b}$ instruments for central government expenditure using distance from district capital to Lusaka; ${ }^{c}$ instruments for central government expenditure using log population and distance from district capital to Lusaka.

Table D 4: Total Expenditure-lower secondary school enrolment

\begin{tabular}{|c|c|c|c|c|c|c|}
\hline Method & OLS & $2 S L S^{a}$ & $2 \mathrm{SLS}^{b}$ & $2 S L S^{c}$ & $\mathrm{GMM}^{c}$ & LIML $^{c}$ \\
\hline ELF-E & .046 & .090 & -.002 & .082 & .037 & .089 \\
\hline Area $(1000 \mathrm{~km} 2)$ & $.002^{\star \star}$ & $.008^{\star \star \star \star}$ & -.003 & $.007^{\star \star \star}$ & $.007^{\star \star \star}$ & $.008^{\star \star \star}$ \\
\hline Poverty & $-.709^{\star \star *}$ & $-.715^{\star \star \star}$ & $-.703^{\star \star \star *}$ & $-.714^{\star \star \star}$ & $-.801^{\star \star \star}$ & $-.715^{\star \star \star}$ \\
\hline Expenditure & -.002 & $-.031^{\star * \star}$ & $.031^{\star *}$ & $-.026^{\star \star \star}$ & $-.019^{\star \star \star}$ & $-.031^{\star \star \star}$ \\
\hline Rural & $-.146^{\star \star *}$ & $-.272^{\star \star \star}$ & -.009 & $-.250^{\star \star \star \star}$ & $-.221^{\star \star \star}$ & $-.271^{\star \star \star}$ \\
\hline 2005 & $.399^{\star \star \star}$ & $.417^{\star \star \star}$ & $.379^{\star \star \star}$ & $.414^{\star \star \star}$ & $.397^{\star \star \star}$ & $.417^{\star \star \star}$ \\
\hline 2006 & $.384^{\star \star \star}$ & $.501^{\star \star \star}$ & $.257^{\star \star \star}$ & $.481^{\star \star \star \star}$ & $.446^{\star \star \star}$ & $.500^{\star \star \star}$ \\
\hline 2007 & $.247^{* * *}$ & $.358^{\text {*k* }}$ & $.128^{\star \star}$ & $.339^{* \star \star *}$ & $.310^{* * *}$ & $.357^{\star \star \star}$ \\
\hline 2008 & $.242^{\star \star \star}$ & $.519^{\star \star \star}$ & -.058 & $.472^{\star \star \star}$ & $.409^{\star \star \star}$ & $.517^{\star \star \star}$ \\
\hline 2009 & $.331^{\star \star \star}$ & $.676^{\star \star \star}$ & -.042 & $.617^{\star \star \star}$ & $.538^{* \star \star}$ & $.674^{\star \star \star}$ \\
\hline Constant & $.869^{\star \star \star}$ & $1.072^{\star \star \star}$ & $.650^{\star \star \star}$ & $1.037^{\star \star \star}$ & $1.050^{\star \star \star}$ & $1.071^{\star \star \star}$ \\
\hline R-squared & .557 & .333 & .293 & .402 & .473 & .336 \\
\hline F-statistic & $58.00^{* * * *}$ & & & & & \\
\hline Wald $X^{2}$ & & $422.73^{* \star \star}$ & $420.91^{\star \star \star}$ & $457.12^{\star \star \star}$ & $516.97^{\star \star \star}$ & $415.65^{\text {*t* }}$ \\
\hline Observations & 408 & 408 & 408 & 408 & 408 & 408 \\
\hline \multicolumn{7}{|c|}{$\begin{array}{l}{ }^{*} p<0.10,{ }^{* *} p<0.05,{ }^{* * *} p<0.01 \text { for robust standard errors } \\
\text { Notes: values show estimated coefficient for ELF-E fractionalization index; }{ }^{a} \text { instruments for central } \\
\text { government expenditure using log population; }{ }^{b} \text { instruments for central government expenditure using } \\
\text { distance from district capital to Lusaka; }{ }^{c} \text { instruments for central government expenditure using log } \\
\text { population and distance from district capital to Lusaka. }\end{array}$} \\
\hline
\end{tabular}


Table D 5: Total Expenditure-teacher pupil ratio 2008

\begin{tabular}{|c|c|c|c|c|c|c|}
\hline Method & OLS & $2 S L S^{a}$ & $2 S L S^{b}$ & $2 S L S^{c}$ & $\mathrm{GMM}^{c}$ & $\operatorname{LIML}^{c}$ \\
\hline ELF-E & .001 & .003 & -.004 & .002 & .003 & .003 \\
\hline Area (1000 km2) & -.000 & .000 & $-.000^{*}$ & -.000 & -.000 & .000 \\
\hline Poverty & $-.013^{\star \star \star}$ & $-.011^{\star * \star}$ & $-.017^{\star \star \star}$ & $-.012^{\star \star \star}$ & $-.011^{\star \star \star}$ & $-.011^{\star \star \star}$ \\
\hline Expenditure & .000 & $-.001^{\star \star \star}$ & $.002^{\star \star}$ & $-.000^{\star \star}$ & $-.001^{\star \star \star}$ & $-.001^{\star \star \star}$ \\
\hline Rural & -.002 & $-.005^{\star * \star}$ & .005 & $-.004^{* *}$ & $-.004^{\star \star}$ & $-.005^{\star \star \star}$ \\
\hline Constant & $.032^{\star \star \star}$ & $.042^{\star \star \star}$ & .010 & $.039^{\star \star \star}$ & $.041^{\star \star \star}$ & $.043^{\star \star \star}$ \\
\hline $\begin{array}{l}\text { R-squared } \\
\text { F-statistic }\end{array}$ & $\begin{array}{c}.358 \\
7.36^{\star \star \star}\end{array}$ & .125 & 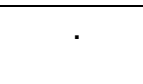 & .256 & .145 & .104 \\
\hline Wald $x^{2}$ & & $37.20^{\star \star \star}$ & $26.39^{\star * *}$ & $35.85^{\star \star \star}$ & $35.09^{\star * \star}$ & $30.61^{\star * \star}$ \\
\hline Observations & 68 & 68 & 68 & 68 & 68 & 68 \\
\hline
\end{tabular}

${ }^{*} p<0.10,{ }^{* *} p<0.05,{ }^{* * *} p<0.01$ for robust standard errors

Notes: values show estimated coefficient for ELF-E fractionalization index; ${ }^{a}$ instruments for central government expenditure using log population; ${ }^{b}$ instruments for central government expenditure using distance from district capital to Lusaka; ${ }^{c}$ instruments for central government expenditure using log population and distance from district capital to Lusaka.

Table D 6: Total Expenditure-basic school teacher pupil ratio 2009

\begin{tabular}{|c|c|c|c|c|c|c|}
\hline Method & OLS & $2 S L S^{a}$ & $2 S L S^{b}$ & $2 S L S^{c}$ & $\mathrm{GMM}^{c}$ & $\operatorname{LIML}^{c}$ \\
\hline ELF-E & .003 & .003 & .003 & .003 & .003 & .003 \\
\hline Area (1000 km2) & -.000 & .000 & -.000 & .000 & .000 & .000 \\
\hline Poverty & $-.014^{\star \star \star}$ & $-.011^{* \star *}$ & $-.023^{\star \star \star}$ & $-.011^{\star \star \star}$ & $-.010^{\star \star \star}$ & $-.010^{\star \star \star}$ \\
\hline Expenditure & -.000 & $-.000^{\star \star \star}$ & .001 & $-.000^{\star \star \star}$ & $-.000^{\star \star \star}$ & $-.000^{\star \star \star}$ \\
\hline Rural & -.002 & $-.004^{\star \star}$ & .005 & $-.004^{\star \star}$ & $-.004^{\star \star}$ & $-.004^{* \star}$ \\
\hline Constant & $.031^{\star \star \star}$ & $.034^{\star \star \star}$ & $.021^{*}$ & $.034^{\star \star \star}$ & $.034^{\star \star \star}$ & $.035^{\star \star *}$ \\
\hline R-squared & .484 & .316 & . & .347 & .300 & .277 \\
\hline F-statistic & $13.09^{\star \star \star}$ & & & & & \\
\hline Wald $x^{2}$ & & $69.27^{\star \star \star}$ & $21.29^{\star \star \star}$ & $70.16^{\star \star \star}$ & $63.45^{\star \star \star}$ & $66.17^{\star \star \star}$ \\
\hline Observations & 68 & 68 & 68 & 68 & 68 & 68 \\
\hline \multicolumn{7}{|c|}{$\begin{array}{l}{ }^{*} p<0.10,{ }^{* \star} p<0.05,{ }^{* *} p<0.01 \text { for robust standard errors } \\
\text { Notes: values show estimated coefficient for ELF-E fractionalization index; a instruments for central } \\
\text { government expenditure using log population; }{ }^{b} \text { instruments for central government expenditure using } \\
\text { distance from district capital to Lusaka; }{ }^{c} \text { instruments for central government expenditure using log } \\
\text { population and distance from district capital to Lusaka. }\end{array}$} \\
\hline
\end{tabular}


Table D 7: Total Expenditure-number of schools 2008

\begin{tabular}{|c|c|c|c|c|c|c|}
\hline Method & OLS & $2 S L S^{a}$ & $2 S L S^{b}$ & $2 S L S^{c}$ & $\mathrm{GMM}^{c}$ & LIML $^{c}$ \\
\hline ELF-E & -14.156 & -40.042 & -22.264 & -38.088 & -35.096 & -38.644 \\
\hline Area (1000 km2) & $1.937^{\star \star \star}$ & $1.152^{\star \star}$ & $1.691^{\star \star}$ & $1.211^{\star *}$ & $1.127^{\star \star}$ & $1.194^{\star *}$ \\
\hline Poverty & 21.512 & 1.845 & 15.352 & 3.329 & 8.163 & 2.907 \\
\hline Expenditure & $9.773^{* \star *}$ & $17.711^{\star \star \star}$ & $12.259^{* *}$ & $17.112^{\star \star \star}$ & $17.242^{\star \star \star}$ & $17.282^{* \star *}$ \\
\hline Rural & -5.004 & 28.228 & 5.404 & 25.720 & 25.224 & 26.433 \\
\hline Constant & $-58.089^{*}$ & $-173.158^{\star \star *}$ & -94.130 & $-164.472^{\star \star \star}$ & $-169.980^{\star \star \star}$ & $-166.942^{\star \star \star}$ \\
\hline $\begin{array}{l}\text { R-squared } \\
\text { F-statistic }\end{array}$ & $\begin{array}{c}.582 \\
22.31^{\star \star \star}\end{array}$ & .363 & .561 & .395 & .388 & .386 \\
\hline Wald $x^{2}$ & & $96.55^{\star \star *}$ & $74.04^{\star \star *}$ & $107.05^{\star \star \star}$ & $103.03^{\star \star \star}$ & $105.19^{\star \star \star}$ \\
\hline Observations & 68 & 68 & 68 & 68 & 68 & 68 \\
\hline
\end{tabular}

${ }^{*} p<0.10,{ }^{* *} p<0.05,{ }^{* * *} p<0.01$ for robust standard errors

Notes: values show estimated coefficient for ELF-E fractionalization index; a instruments for central government expenditure using log population; ${ }^{b}$ instruments for central government expenditure using distance from district capital to Lusaka; ${ }^{c}$ instruments for central government expenditure using log population and distance from district capital to Lusaka.

Table D 8: Total Expenditure-number of teachers 2008

\begin{tabular}{|c|c|c|c|c|c|c|}
\hline Method & OLS & $2 S L S^{a}$ & $2 S L S^{b}$ & $2 S L S^{c}$ & $\mathrm{GMM}^{\mathrm{c}}$ & LIML $^{c}$ \\
\hline ELF-E & 84.765 & -62.003 & -157.748 & -72.526 & -91.064 & -74.558 \\
\hline Area (1000 km2) & .740 & -3.711 & -6.615 & -4.030 & -3.530 & -4.092 \\
\hline Poverty & $-729.187^{\star \star \star}$ & $-840.693^{\star \star \star}$ & $-913.436^{\star \star \star}$ & $-848.688^{\star \star \star}$ & $-886.822^{\star \star \star}$ & $-850.232^{\star \star \star}$ \\
\hline Expenditure & $97.385^{\star \star \star}$ & $142.390^{\star \star \star}$ & $171.749^{\star \star \star}$ & $145.617^{\star \star \star}$ & $146.285^{\star \star \star}$ & $146.240^{\star \star \star}$ \\
\hline Rural & $-249.580^{\star *}$ & -61.163 & 61.754 & -47.653 & -44.652 & -45.045 \\
\hline Constant & 121.031 & -531.374 & -956.978 & $-578.151^{\star}$ & -568.234 & $-587.183^{\star}$ \\
\hline $\begin{array}{l}\text { R-squared } \\
\text { F-statistic }\end{array}$ & $\begin{array}{c}.769 \\
34.96^{\star \star \star}\end{array}$ & .698 & .577 & .688 & .686 & .686 \\
\hline Wald $x^{2}$ & & $130.48^{\star * \star}$ & $82.51^{\star \star \star}$ & $135.42^{\star \star \star}$ & $137.58^{\star * \star}$ & $134.47^{\star \star \star}$ \\
\hline Observations & 68 & 68 & 68 & 68 & 68 & 68 \\
\hline
\end{tabular}

${ }^{*} p<0.10,{ }^{* *} p<0.05,{ }^{* * *} p<0.01$ for robust standard errors

Notes: values show estimated coefficient for ELF-E fractionalization index; a instruments for central government expenditure using log population; ${ }^{b}$ instruments for central government expenditure using distance from district capital to Lusaka; ${ }^{c}$ instruments for central government expenditure using log population and distance from district capital to Lusaka.

Table D 9: Total Expenditure-number of basic schools 2009

\begin{tabular}{|c|c|c|c|c|c|c|}
\hline Method & OLS & $2 S L S^{a}$ & $2 S L S^{b}$ & $2 S L S^{c}$ & $\mathrm{GMM}^{c}$ & $\operatorname{LIML}^{c}$ \\
\hline ELF-E & 12.332 & 10.433 & 10.218 & 10.428 & 10.081 & 10.428 \\
\hline Area $(1000$ km2) & $1.360^{\star \star \star}$ & .305 & .186 & .302 & .309 & .302 \\
\hline Poverty & 3.145 & -32.284 & -36.290 & -32.377 & -32.351 & -32.385 \\
\hline Expenditure & $4.514^{\star \star \star}$ & $7.754^{\star \star \star}$ & $8.121^{*}$ & $7.763^{\star \star \star}$ & $7.758^{\star \star \star}$ & $7.764^{\star \star *}$ \\
\hline Rural & -4.744 & 23.327 & 26.501 & 23.400 & 23.254 & 23.407 \\
\hline Constant & 18.652 & -22.799 & -27.486 & -22.908 & -22.601 & -22.917 \\
\hline R-squared & .669 & .447 & .394 & .446 & .446 & .446 \\
\hline F-statistic & $31.91^{\star * \star}$ & & & & & \\
\hline Wald $x^{2}$ & & $90.94^{\star \star \star}$ & $45.72^{\star \star \star}$ & $91.67^{\star \star \star}$ & $92.42^{\star \star \star}$ & $91.65^{\star \star \star}$ \\
\hline Observations & 68 & 68 & 68 & 68 & 68 & 68 \\
\hline
\end{tabular}

${ }^{*} p<0.10,{ }^{* *} p<0.05,{ }^{* \star *} p<0.01$ for robust standard errors

Notes: values show estimated coefficient for ELF-E fractionalization index; ${ }^{a}$ instruments for central government expenditure using log population; ${ }^{b}$ instruments for central government expenditure using distance from district capital to Lusaka; ${ }^{c}$ instruments for central government expenditure using log population and distance from district capital to Lusaka. 
Table D 10: Total Expenditure-maternal mortality

\begin{tabular}{|c|c|c|c|c|c|c|}
\hline Method & OLS & $2 S L S^{a}$ & $2 S L S^{b}$ & $2 S L S^{c}$ & $\mathrm{GMM}^{c}$ & LIML $^{c}$ \\
\hline ELF-E & -54.878 & -58.594 & -27.418 & -54.081 & -80.523 & -53.974 \\
\hline Area (1000 km2) & -1.241 & -2.146 & 5.445 & -1.047 & -1.217 & -1.021 \\
\hline Poverty & 465.176 & 428.211 & $738.298^{\star *}$ & $473.103^{*}$ & 197.088 & $474.166^{*}$ \\
\hline Expenditure & $8.918^{*}$ & $25.639^{* *}$ & $-114.624^{\star \star}$ & 5.332 & 3.994 & 4.852 \\
\hline Rural & -16.631 & 89.060 & $-797.529^{\star \star}$ & -39.295 & -17.215 & -42.333 \\
\hline 2005 & -33.729 & -36.089 & -16.294 & -33.223 & 1.119 & -33.155 \\
\hline 2006 & -33.817 & -71.192 & $242.323^{*}$ & -25.803 & 7.274 & -24.729 \\
\hline 2007 & $-81.468^{\star}$ & $-142.725^{\star *}$ & $371.130^{\star *}$ & -68.332 & -33.038 & -66.572 \\
\hline 2008 & 26.228 & -60.865 & $669.719^{\star *}$ & 44.905 & -62.007 & 47.407 \\
\hline Constant & -12.604 & -79.837 & $484.147^{\star}$ & 1.814 & 149.158 & 3.746 \\
\hline R-squared & .037 & .027 & & .036 & .005 & .036 \\
\hline F-statistic & $4.09^{\star \star \star}$ & & & & & \\
\hline Wald $x^{2}$ & & $30.03^{\star \star \star \star ~}$ & 11.80 & $27.00^{\star \star \star *}$ & $19.18^{\star \star}$ & $26.63^{\star \star \star}$ \\
\hline Observations & 320 & 320 & 320 & 320 & 320 & 320 \\
\hline \multicolumn{7}{|c|}{$\begin{array}{l}{ }^{*} p<0.10,{ }^{* *} p<0.05,{ }^{* * *} p<0.01 \text { for robust standard errors } \\
\text { Notes: values show estimated coefficient for ELF-E fractionalization index; }{ }^{a} \text { instruments for central } \\
\text { government expenditure using log population; }{ }^{b} \text { instruments for central government expenditure using } \\
\text { distance from district capital to Lusaka; }{ }^{c} \text { instruments for central government expenditure using log } \\
\text { population and distance from district capital to Lusaka. }\end{array}$} \\
\hline
\end{tabular}

Table D 11: Total Expenditure-under 5 mortality

\begin{tabular}{|c|c|c|c|c|c|c|}
\hline Method & OLS & $2 S L^{a}$ & $2 \mathrm{SLS}^{b}$ & $2 S L S^{c}$ & $\mathrm{GMM}^{c}$ & $\operatorname{LIML}^{c}$ \\
\hline ELF-E & -7.209 & -7.301 & -11.197 & -7.835 & -20.042 & -7.977 \\
\hline Area $(1000 \mathrm{~km} 2)$ & -.341 & $-.360^{*}$ & $-1.186^{* *}$ & $-.473^{* *}$ & $-.487^{* *}$ & $-.503^{\star \star \star}$ \\
\hline Poverty & $33.762^{\star *}$ & $33.022^{\star \star}$ & 1.512 & $28.702^{\star \star}$ & 9.698 & $27.549^{\star}$ \\
\hline Expenditure & .515 & .846 & $14.933^{\star \star \star}$ & $2.777^{\star}$ & $4.029^{* *}$ & $3.293^{*}$ \\
\hline Rural & 5.526 & 7.646 & $97.960^{\star *}$ & $20.028^{*}$ & $24.623^{\star \star}$ & $23.332^{*}$ \\
\hline 2005 & 1.263 & 1.219 & -.669 & .960 & -1.561 & 891 \\
\hline 2006 & -.986 & -1.718 & $-32.880^{* *}$ & -5.990 & $-14.344^{\star \star}$ & -7.130 \\
\hline 2007 & $-15.455^{\star *}$ & $-16.639^{* *}$ & $-67.041^{\star \star \star}$ & $-23.549^{\star \star \star}$ & $-30.701^{\star \star \star}$ & $-25.393^{\star \star \star *}$ \\
\hline 2008 & $-29.416^{\star \star \star}$ & $-31.124^{\star \star \star}$ & $-103.872^{\star \star \star}$ & $-41.098^{\star \star \star}$ & $-49.878^{\star \star \star}$ & $-43.760^{\star * \star}$ \\
\hline Constant & $43.469^{\star \star \star}$ & $42.140^{\star *}$ & -14.455 & $34.381^{*}$ & $47.647^{\star \star \star}$ & $32.310^{*}$ \\
\hline R-squared & .128 & .128 & & .099 & .048 & .085 \\
\hline F-statistic & $7.92^{* \star *}$ & & & & & \\
\hline Wald $x^{2}$ & & $77.61^{\star \star \star}$ & $33.44^{\star \star \star *}$ & $82.80^{\star \star \star}$ & $83.48^{\star \star \star *}$ & $80.76^{\star \star \star}$ \\
\hline Observations & 329 & 329 & 329 & 329 & 329 & 329 \\
\hline
\end{tabular}

${ }^{*} p<0.10,{ }^{* *} p<0.05,{ }^{* * *} p<0.01$ for robust standard errors

Notes: values show estimated coefficient for ELF-E fractionalization index; ${ }^{a}$ instruments for central government expenditure using log population; ${ }^{b}$ instruments for central government expenditure using distance from district capital to Lusaka; ${ }^{c}$ instruments for central government expenditure using log population and distance from district capital to Lusaka. 
Table D 12: Total Expenditure-total beds per 1000

\begin{tabular}{|c|c|c|c|c|c|c|}
\hline Method & OLS & $2 S L S^{a}$ & $2 S L S^{b}$ & $2 S L S^{c}$ & $\mathrm{GMM}^{c}$ & LIML $^{c}$ \\
\hline ELF-E & $-1.589^{\star \star \star}$ & $-1.486^{\star \star}$ & $-1.745^{* \star *}$ & $-1.521^{\star \star *}$ & $-1.743^{\star \star \star}$ & $-1.494^{\star \star}$ \\
\hline Area (1000 km2) & .003 & $.025^{\star \star}$ & -.030 & $.018^{\star \star}$ & $.019^{\star \star}$ & $.023^{\star \star}$ \\
\hline Poverty & -.063 & .770 & -1.323 & .483 & .497 & .705 \\
\hline Expenditure & .028 & $-.345^{\star \star \star}$ & $.591^{\star \star \star}$ & $-.217^{\star \star \star}$ & $-.134^{\star \star}$ & $-.316^{\star \star \star}$ \\
\hline Rural & $-.704^{*}$ & $-3.092^{\star * \star}$ & $2.908^{\star \star}$ & $-2.269^{\star \star \star}$ & $-1.926^{\star * \star}$ & $-2.907^{\star \star \star}$ \\
\hline 2005 & -.101 & -.051 & -.176 & -.068 & -.020 & -.055 \\
\hline 2006 & -.142 & $.682^{\star \star}$ & $-1.388^{\star \star \star}$ & .398 & .247 & $.618^{*}$ \\
\hline 2007 & -.191 & $1.142^{\star \star \star}$ & $-2.207^{\star \star \star}$ & $.683^{\star *}$ & .489 & $1.039^{\star *}$ \\
\hline 2008 & -.050 & $1.874^{\star \star \star}$ & $-2.959^{\star \star \star}$ & $1.211^{\star \star \star}$ & $1.106^{\star \star \star}$ & $1.725^{\star \star \star}$ \\
\hline Constant & $3.380^{\star \star \star}$ & $4.876^{\star \star \star}$ & 1.116 & $4.361^{\star \star \star}$ & $3.867^{\star \star \star}$ & $4.760^{\star \star \star}$ \\
\hline R-squared & .058 & . & . & . & . & . \\
\hline F-statistic & $2.26^{\star *}$ & & & & & \\
\hline Wald $x^{2}$ & & $36.45^{\star \star *}$ & $21.39^{\star \star}$ & $30.77^{\star \star \star}$ & $23.97^{\star \star \star}$ & $28.12^{\star \star \star}$ \\
\hline Observations & 329 & 329 & 329 & 329 & 329 & 329 \\
\hline \multicolumn{7}{|c|}{$\begin{array}{l}{ }^{*} p<0.10,{ }^{* *} p<0.05,{ }^{* * *} p<0.01 \text { for robust standard errors } \\
\text { Notes: values show estimated coefficient for ELF-E fractionalization index; a instruments for central } \\
\text { government expenditure using log population; }{ }^{b} \text { instruments for central government expenditure using } \\
\text { distance from district capital to Lusaka; }{ }^{c} \text { instruments for central government expenditure using log } \\
\text { population and distance from district capital to Lusaka. }\end{array}$} \\
\hline
\end{tabular}

Table D 13: Total Expenditure-BCG immunization rate

\begin{tabular}{|c|c|c|c|c|c|c|}
\hline Method & OLS & $2 S L S^{a}$ & $2 S L S^{b}$ & $2 S L S^{c}$ & $\mathrm{GMM}^{c}$ & LIML $^{c}$ \\
\hline ELF-E & $.190^{\star \star \star}$ & $.186^{\star \star \star}$ & $.176^{\star \star \star}$ & $.185^{\star \star \star}$ & $.173^{\star \star \star}$ & $.185^{\star \star \star}$ \\
\hline Area (1000 km2) & .001 & .000 & -.002 & .000 & .000 & .000 \\
\hline Poverty & $.374^{\star \star \star}$ & $.340^{* \star *}$ & $.262^{\star *}$ & $.329^{\star \star \star}$ & $.308^{\star \star \star}$ & $.328^{\star \star \star}$ \\
\hline Expenditure & $.014^{\star \star \star}$ & $.030^{\star \star}$ & $.065^{\star *}$ & $.034^{\star \star \star}$ & $.036^{\star \star \star}$ & $.035^{\star \star \star}$ \\
\hline Rural & $.106^{\star \star}$ & $.204^{\star *}$ & $.428^{\star \star}$ & $.234^{\star \star \star}$ & $.241^{\star \star \star}$ & $.238^{\star \star \star}$ \\
\hline 2005 & -.028 & -.030 & -.035 & -.031 & -.030 & -.031 \\
\hline 2006 & -.024 & -.058 & $-.135^{\star}$ & -.069 & -.066 & -.070 \\
\hline 2007 & $-.091^{* *}$ & $-.146^{\star \star \star}$ & $-.271^{\star \star}$ & $-.163^{\star \star \star}$ & $-.167^{\star \star \star}$ & $-.165^{\star \star \star}$ \\
\hline 2008 & -.062 & $-.140^{\star}$ & $-.321^{\star *}$ & $-.165^{\star \star}$ & $-.177^{\star \star}$ & $-.168^{\star \star}$ \\
\hline Constant & $.796^{\star \star \star}$ & $.734^{* \star *}$ & $.594^{\star \star \star}$ & $.715^{\star \star \star}$ & $.725^{\star \star \star}$ & $.713^{\star \star *}$ \\
\hline R-squared & .137 & .102 & . & .077 & .069 & .073 \\
\hline F-statistic & $6.59^{\star \star \star}$ & & & & & \\
\hline Wald $x^{2}$ & & $58.85^{\star \star \star}$ & $37.15^{\star \star \star}$ & $58.28^{\star \star *}$ & $55.99^{\star \star \star}$ & $57.81^{\star \star \star}$ \\
\hline Observations & 329 & 329 & 329 & 329 & 329 & 329 \\
\hline
\end{tabular}

${ }^{*} p<0.10,{ }^{* *} p<0.05,{ }^{* * *} p<0.01$ for robust standard errors

Notes: values show estimated coefficient for ELF-E fractionalization index; ${ }^{a}$ instruments for central government expenditure using log population; ${ }^{b}$ instruments for central government expenditure using distance from district capital to Lusaka; ${ }^{c}$ instruments for central government expenditure using log population and distance from district capital to Lusaka. 
Table D 14: Total Expenditure—DPT3 immunization rate

\begin{tabular}{|c|c|c|c|c|c|c|}
\hline Method & OLS & $2 \mathrm{SLS}^{a}$ & $2 \mathrm{SLS}^{b}$ & $2 S L S^{c}$ & $\mathrm{GMM}^{c}$ & LIML $^{c}$ \\
\hline ELF-E & $.238^{\star \star \star *}$ & $.229^{* \star \star}$ & $.202^{\star *}$ & $.225^{\star \star \star}$ & $.226^{\star \star \star *}$ & $.223^{\star \star \star \star}$ \\
\hline Area $(1000 \mathrm{~km} 2)$ & .002 & .000 & -.005 & -.000 & -.000 & -.001 \\
\hline Poverty & $.168^{*}$ & .094 & -.118 & .065 & .050 & .046 \\
\hline Expenditure & $.009^{*}$ & $.042^{\star \star \star}$ & $.136^{\star \star \star}$ & $.055^{\star \star \star}$ & $.048^{\star \star \star}$ & $.063^{\star \star \star}$ \\
\hline Rural & $.131^{\star \star}$ & $.344^{\star \star \star \star}$ & $.951^{\star \star \star}$ & $.427^{\star \star \star}$ & $.402^{\star \star \star \star}$ & $.480^{\star \star \star \star}$ \\
\hline 2005 & .009 & .004 & -.008 & .003 & .004 & .002 \\
\hline 2006 & $-.102^{\star *}$ & $-.175^{\star \star \star}$ & $-.385^{\star \star \star}$ & $-.204^{\star \star \star}$ & $-.194^{\star \star *}$ & $-.222^{\star \star \star *}$ \\
\hline 2007 & $-.199^{\star \star \star *}$ & $-.317^{\star \star *}$ & $-.656^{\star \star \star}$ & $-.364^{\star \star \star}$ & $-.334^{\star \star *}$ & $-.393^{\star \star \star}$ \\
\hline 2008 & $-.124^{\star *}$ & $-.295^{\star \star \star}$ & $-.784^{\star \star \star}$ & $-.362^{* \star *}$ & $-.333^{\star \star *}$ & $-.405^{\star \star \star}$ \\
\hline Constant & $.851^{* * \star}$ & $.718^{* \star * *}$ & .337 & $.666^{\star \star \star *}$ & $.693^{* * *}$ & $.633^{\star \star \star *}$ \\
\hline R-squared & .159 & .015 & . & 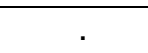 & & . \\
\hline F-statistic & $8.47^{\star \star \star}$ & & & & & \\
\hline Wald $x^{2}$ & & $87.92^{* \star *}$ & $34.98^{\star * \star}$ & $88.28^{* \star *}$ & $87.24^{\star \star *}$ & $81.26^{\star \star \star}$ \\
\hline Observations & 329 & 329 & 329 & 329 & 329 & 329 \\
\hline \multicolumn{7}{|c|}{$\begin{array}{l}{ }^{*} p<0.10,{ }^{* *} p<0.05,{ }^{* * *} p<0.01 \text { for robust standard errors } \\
\text { Notes: values show estimated coefficient for ELF-E fractionalization index; }{ }^{a} \text { instruments for central } \\
\text { government expenditure using log population; }{ }^{b} \text { instruments for central government expenditure using } \\
\text { distance from district capital to Lusaka; }{ }^{c} \text { instruments for central government expenditure using log } \\
\text { population and distance from district capital to Lusaka. }\end{array}$} \\
\hline
\end{tabular}

Table D 15: Total Expenditure-OPV3 immunization rate

\begin{tabular}{|c|c|c|c|c|c|c|}
\hline Method & OLS & $2 \mathrm{SLS}^{a}$ & $2 \mathrm{SLS}^{b}$ & $2 \mathrm{SLS}^{c}$ & $\mathrm{GMM}^{c}$ & $\operatorname{LIML}^{c}$ \\
\hline ELF-E & $.270^{\star * \star}$ & $.261^{* \star *}$ & $.232^{* *}$ & $.257^{\star \star \star}$ & $.249^{* \star *}$ & $.254^{\star * \star}$ \\
\hline Area $(1000 \mathrm{~km} 2)$ & -.000 & -.002 & $-.008^{\star}$ & -.003 & -.003 & $-.004^{\star}$ \\
\hline Poverty & $.165^{\star}$ & .088 & -.147 & .056 & .044 & .035 \\
\hline Expenditure & $.010^{* *}$ & $.044^{\star \star \star}$ & $.149^{\star \star \star}$ & $.059^{\star \star \star}$ & $.048^{\star \star \star}$ & $.068^{\star \star \star}$ \\
\hline Rural & $.156^{\star \star \star}$ & $.377^{\star \star \star}$ & $1.050^{* * *}$ & $.469^{\star \star \star *}$ & $.417^{\star \star \star}$ & $.529^{* \star *}$ \\
\hline 2005 & $-.140^{\star * *}$ & $-.144^{\star \star \star}$ & $-.158^{*}$ & $-.146^{\star \star \star}$ & $-.148^{\star \star \star}$ & $-.147^{\star \star \star}$ \\
\hline 2006 & $-.130^{* \star *}$ & $-.206^{\star \star *}$ & $-.438^{* \star *}$ & $-.238^{\star \star \star *}$ & $-.219^{* \star *}$ & $-.258^{* \star \star}$ \\
\hline 2007 & $-.280^{* * \star}$ & $-.403^{* \star *}$ & $-.779^{\star \star \star}$ & $-.455^{\star \star \star}$ & $-.407^{* \star *}$ & $-.488^{* * \star}$ \\
\hline 2008 & $-.153^{\star \star \star}$ & $-.330^{\star \star *}$ & $-.872^{\star \star *}$ & $-.405^{\star \star \star}$ & $-.349^{\star \star \star}$ & $-.453^{\star \star \star}$ \\
\hline Constant & $.880^{\star * *}$ & $.742^{\star \star \star}$ & .320 & $.684^{\star \star \star}$ & $.737^{\star \star \star}$ & $.647^{\star \star \star}$ \\
\hline R-squared & .163 & .030 & & . & .002 & . \\
\hline F-statistic & $7.31^{* \star *}$ & & & & & \\
\hline Wald $x^{2}$ & & $64.65^{\star \star *}$ & $28.92^{\star \star \star}$ & $63.32^{\star \star \star *}$ & $60.68^{\star \star \star *}$ & $58.50^{\star * \star}$ \\
\hline Observations & 329 & 329 & 329 & 329 & 329 & 329 \\
\hline
\end{tabular}

${ }^{*} p<0.10,{ }^{* *} p<0.05,{ }^{* * *} p<0.01$ for robust standard errors

Notes: values show estimated coefficient for ELF-E fractionalization index; ${ }^{a}$ instruments for central government expenditure using log population; ${ }^{b}$ instruments for central government expenditure using distance from district capital to Lusaka; ${ }^{c}$ instruments for central government expenditure using log population and distance from district capital to Lusaka. 
Table D 16: Total Expenditure-measles immunization rate

\begin{tabular}{|c|c|c|c|c|c|c|}
\hline Method & OLS & $2 S L S^{a}$ & $2 S L S^{b}$ & $2 S L S^{c}$ & $\mathrm{GMM}^{c}$ & $\operatorname{LIML}^{c}$ \\
\hline ELF-E & $.201^{* \star *}$ & $.192^{\star \star \star}$ & $.188^{\star \star \star}$ & $.192^{\star \star \star}$ & $.192^{\star \star \star}$ & $.192^{* \star *}$ \\
\hline Area (1000 km2) & -.001 & -.003 & -.004 & $-.003^{*}$ & $-.003^{*}$ & $-.003^{\star}$ \\
\hline Poverty & $.186^{\star *}$ & .118 & .085 & .113 & .123 & .113 \\
\hline Expenditure & $.013^{\star \star}$ & $.043^{\star \star \star}$ & $.058^{\star \star}$ & $.045^{\star \star \star}$ & $.045^{\star \star \star}$ & $.045^{\star \star \star}$ \\
\hline Rural & $.126^{\star \star \star}$ & $.323^{\star \star \star}$ & $.417^{\star *}$ & $.336^{\star \star \star}$ & $.332^{\star \star \star}$ & $.337^{\star \star \star}$ \\
\hline 2005 & .013 & .009 & .007 & .009 & .007 & .009 \\
\hline 2006 & .011 & -.057 & -.089 & -.061 & -.061 & -.062 \\
\hline 2007 & -.003 & $-.113^{\star \star}$ & -.165 & $-.120^{\star \star}$ & $-.114^{\star \star}$ & $-.120^{\star \star}$ \\
\hline 2008 & -.034 & $-.192^{\star \star \star}$ & $-.268^{\star}$ & $-.203^{\star \star \star}$ & $-.203^{\star \star \star}$ & $-.203^{\star \star \star}$ \\
\hline Constant & $.697^{\star \star \star}$ & $.574^{\star \star \star}$ & $.515^{\star \star \star}$ & $.566^{\star \star \star}$ & $.563^{\star \star \star}$ & $.565^{\star \star \star}$ \\
\hline R-squared & .088 & . & $\cdot$ & . & . & . \\
\hline F-statistic & $3.32^{* \star *}$ & & & & & \\
\hline Wald $x^{2}$ & & $39.47^{\star \star \star}$ & $25.44^{\star \star *}$ & $41.80^{\star \star \star}$ & $41.61^{\star \star \star}$ & $41.72^{\star \star \star}$ \\
\hline Observations & 329 & 329 & 329 & 329 & 329 & 329 \\
\hline \multicolumn{7}{|c|}{$\begin{array}{l}{ }^{*} p<0.10,{ }^{* *} p<0.05,{ }^{* * *} p<0.01 \text { for robust standard errors } \\
\text { Notes: values show estimated coefficient for ELF-E fractionalization index; a instruments for central } \\
\text { government expenditure using log population; }{ }^{b} \text { instruments for central government expenditure using } \\
\text { distance from district capital to Lusaka; }{ }^{c} \text { instruments for central government expenditure using log } \\
\text { population and distance from district capital to Lusaka. }\end{array}$} \\
\hline
\end{tabular}

Table D 17: Total Expenditure-FIC immunization rate

\begin{tabular}{|c|c|c|c|c|c|c|}
\hline Method & OLS & $2 S L S^{a}$ & $2 S L S^{b}$ & $2 S L S^{c}$ & $\mathrm{GMM}^{c}$ & LIML $^{c}$ \\
\hline ELF-E & $.362^{\star \star \star}$ & $.358^{\star \star \star}$ & $.338^{\star \star \star}$ & $.356^{\star \star \star}$ & $.366^{\star \star \star}$ & $.354^{\star \star \star}$ \\
\hline Area (1000 km2) & $-.004^{\star \star \star}$ & $-.005^{\star \star \star}$ & $-.009^{\star \star \star}$ & $-.005^{\star \star \star}$ & $-.005^{\star \star \star}$ & $-.006^{\star \star \star}$ \\
\hline Poverty & .017 & -.011 & -.179 & -.034 & -.051 & -.049 \\
\hline Expenditure & $.009^{\star *}$ & $.021^{\star \star}$ & $.096^{\star \star \star}$ & $.031^{\star \star \star}$ & $.032^{\star \star \star}$ & $.038^{\star \star \star}$ \\
\hline Rural & $.072^{\star}$ & $.149^{\star *}$ & $.632^{\star \star \star}$ & $.216^{\star \star \star}$ & $.228^{\star \star \star}$ & $.259^{\star \star \star}$ \\
\hline 2005 & .023 & .021 & .011 & .020 & .012 & .019 \\
\hline 2006 & $.053^{*}$ & .026 & $-.141^{*}$ & .003 & -.002 & -.012 \\
\hline 2007 & -.010 & -.053 & $-.323^{\star \star \star}$ & $-.090^{\star \star}$ & $-.093^{\star \star}$ & $-.114^{\star \star}$ \\
\hline 2008 & .041 & -.022 & $-.411^{\star *}$ & -.075 & -.096 & -.110 \\
\hline Constant & $.631^{\star \star \star}$ & $.582^{\star \star \star}$ & $.280^{*}$ & $.541^{\star \star \star}$ & $.544^{\star \star \star}$ & $.514^{\star \star \star}$ \\
\hline R-squared & .268 & .233 & . & .147 & .138 & .064 \\
\hline F-statistic & $13.54^{\star \star \star}$ & & & & & \\
\hline Wald $x^{2}$ & & $133.25^{\star * \star}$ & $47.21^{\star \star *}$ & $148.57^{\star \star \star}$ & $155.76^{\star \star \star}$ & $136.22^{\star \star \star}$ \\
\hline Observations & 329 & 329 & 329 & 329 & 329 & 329 \\
\hline
\end{tabular}

Observations $\quad 329 \quad 329 \quad 329$

Notes: values show estimated coefficient for ELF-E fractionalization index; $a$ instruments for central government expenditure using log population; ${ }^{b}$ instruments for central government expenditure using distance from district capital to Lusaka; ${ }^{c}$ instruments for central government expenditure using log population and distance from district capital to Lusaka. 
Table D 18: Total Expenditure-underweight5

\begin{tabular}{|c|c|c|c|c|c|c|}
\hline Method & OLS & $2 S L S^{a}$ & $2 S L S^{b}$ & $2 S L S^{c}$ & $\mathrm{GMM}^{c}$ & LIML $^{c}$ \\
\hline ELF-E & $-12.981^{\star \star \star}$ & $-12.979^{\star \star \star}$ & $-12.711^{\star \star \star}$ & $-12.942^{\star \star \star}$ & $-13.354^{\star \star \star}$ & $-12.941^{\star \star \star}$ \\
\hline Area (1000 km2) & -.021 & -.021 & .036 & -.013 & -.021 & -.013 \\
\hline Poverty & $4.212^{\star \star}$ & $4.224^{\star *}$ & $6.398^{\star \star}$ & $4.522^{\star \star}$ & $4.427^{\star \star}$ & $4.537^{\star \star}$ \\
\hline Expenditure & .120 & .115 & -.857 & -.018 & -.047 & -.025 \\
\hline Rural & $2.932^{\star \star \star}$ & $2.898^{*}$ & -3.334 & 2.043 & 1.922 & 1.998 \\
\hline 2005 & -.861 & -.860 & -.730 & -.843 & -.763 & -.842 \\
\hline 2006 & $-3.415^{\star * \star}$ & $-3.404^{\star * \star}$ & -1.254 & $-3.109^{\star \star \star}$ & $-2.918^{\star \star \star}$ & $-3.093^{\star \star \star}$ \\
\hline 2007 & $-7.737^{\star \star \star}$ & $-7.718^{\star \star \star}$ & -4.240 & $-7.241^{\star \star \star}$ & $-6.880^{\star \star \star}$ & $-7.216^{\star \star \star}$ \\
\hline 2008 & $-12.119^{\star \star \star}$ & $-12.092^{\star \star \star}$ & $-7.072^{*}$ & $-11.404^{\star \star \star}$ & $-11.042^{\star \star \star}$ & $-11.367^{\star \star \star}$ \\
\hline Constant & $17.296^{\star \star \star}$ & $17.317^{\star \star \star}$ & $21.222^{\star * \star}$ & $17.853^{\star * \star}$ & $18.188^{\star \star \star}$ & $17.881^{\star \star \star}$ \\
\hline R-squared & .603 & .603 & .472 & .600 & .598 & .600 \\
\hline F-statistic & $70.78^{\star \star \star}$ & & & & & \\
\hline Wald $x^{2}$ & & $665.40^{\star * *}$ & $388.81^{\star \star \star}$ & $660.27^{\star \star \star}$ & $665.28^{\star * \star}$ & $659.23^{\star \star \star}$ \\
\hline Observations & 329 & 329 & 329 & 329 & 329 & 329 \\
\hline \multicolumn{7}{|c|}{$\begin{array}{l}{ }^{*} p<0.10,{ }^{* \star} p<0.05,{ }^{* \star *} p<0.01 \text { for robust standard errors } \\
\text { Notes: values show estimated coefficient for ELF-E fractionalization index; a instruments for central } \\
\text { government expenditure using log population; }{ }^{b} \text { instruments for central government expenditure using } \\
\text { distance from district capital to Lusaka; }{ }^{c} \text { instruments for central government expenditure using log } \\
\text { population and distance from district capital to Lusaka. }\end{array}$} \\
\hline
\end{tabular}

Table D 19: Total Expenditure-HC_Staffpc

\begin{tabular}{|c|c|c|c|c|c|c|}
\hline Method & OLS & $2 S L S^{a}$ & $2 S L S^{b}$ & $2 S L S^{c}$ & $\mathrm{GMM}^{c}$ & LIML $^{c}$ \\
\hline ELF-E & $2.554^{\star \star \star}$ & $2.686^{\star \star \star}$ & $2.169^{\star \star}$ & $2.615^{\star \star \star}$ & $2.413^{\star \star \star}$ & $2.946^{\star \star}$ \\
\hline Area $(1000 \mathrm{~km} 2)$ & $-.072^{\star \star \star}$ & $-.044^{\star \star \star}$ & $-.153^{\star \star \star}$ & $-.059^{\star \star \star}$ & $-.054^{\star \star \star}$ & .012 \\
\hline Poverty & $-3.272^{\star \star \star}$ & $-2.207^{\star \star}$ & $-6.384^{\star \star \star}$ & $-2.780^{\star \star \star}$ & $-4.121^{\star \star \star}$ & -.101 \\
\hline Expenditure & .017 & $-.459^{\star \star \star}$ & $1.409^{\star \star \star}$ & $-.203^{\star}$ & $.211^{\star \star}$ & -1.400 \\
\hline Rural & $-1.071^{\star * *}$ & $-4.124^{\star \star \star}$ & $7.848^{\star \star}$ & $-2.483^{\star \star \star}$ & -.101 & -10.161 \\
\hline 2005 & .019 & .083 & -.167 & .049 & .051 & .209 \\
\hline 2006 & .042 & $1.095^{\star \star}$ & $-3.035^{\star *}$ & .529 & -.593 & 3.178 \\
\hline 2007 & .073 & $1.776^{\star \star \star}$ & $-4.905^{\star * \star}$ & $.860^{*}$ & -.718 & 5.145 \\
\hline 2008 & -.404 & $2.055^{\star \star \star}$ & $-7.588^{\star \star *}$ & .733 & $-1.241^{\star *}$ & 6.918 \\
\hline Constant & $7.337^{\star \star \star}$ & $9.250^{\star \star \star}$ & 1.748 & $8.221^{\star \star \star}$ & $6.577^{\star \star \star}$ & $13.033^{\star \star \star}$ \\
\hline R-squared & .491 & .113 & . & .410 & .404 & . \\
\hline F-statistic & $54.69^{\star \star \star}$ & & & & & \\
\hline Wald $x^{2}$ & & $117.82^{\star * \star}$ & $34.33^{\star \star \star}$ & $260.60^{\star \star \star}$ & $417.19^{\star \star \star}$ & $19.04^{\star \star}$ \\
\hline Observations & 329 & 329 & 329 & 329 & 329 & 329 \\
\hline
\end{tabular}

${ }^{*} p<0.10,{ }^{* *} p<0.05,{ }^{* * *} p<0.01$ for robust standard errors

Notes: values show estimated coefficient for ELF-E fractionalization index; a instruments for central government expenditure using log population; ${ }^{b}$ instruments for central government expenditure using distance from district capital to Lusaka; ${ }^{c}$ instruments for central government expenditure using log population and distance from district capital to Lusaka. 
Table D 20: Total Expenditure-Hosp_OPDStaffpc

\begin{tabular}{|c|c|c|c|c|c|c|}
\hline Method & OLS & $2 S L S^{a}$ & $2 S L S^{b}$ & $2 S^{2} S^{c}$ & $\mathrm{GMM}^{c}$ & $\operatorname{LIML}^{c}$ \\
\hline ELF-E & $.284^{*}$ & $.350^{*}$ & .218 & $.327^{*}$ & .085 & $.334^{*}$ \\
\hline Area (1000 km2) & $-.011^{\star \star \star}$ & $-.008^{* *}$ & $-.014^{\star * \star}$ & $-.009^{\star \star *}$ & -.005 & $-.008^{* *}$ \\
\hline Poverty & $-.573^{\star \star \star}$ & -.314 & $-.835^{\star \star \star}$ & $-.407^{\star}$ & $-.537^{\star \star \star *}$ & $-.377^{\star}$ \\
\hline Expenditure & .007 & $-.083^{\star \star \star}$ & $.097^{\star \star}$ & $-.050^{\star \star}$ & $-.041^{\star}$ & $-.061^{\star *}$ \\
\hline Rural & $-.392^{\star \star \star \star}$ & $-.885^{\star \star \star}$ & .106 & $-.708^{\star \star \star}$ & $-.775^{\star \star \star}$ & $-.766^{\star \star \star}$ \\
\hline 2005 & .007 & .024 & -.011 & .018 & -.040 & .020 \\
\hline 2006 & .022 & $.253^{\star}$ & -.210 & 170 & .097 & 197 \\
\hline 2007 & .043 & $.414^{* * *+}$ & $-.331^{*}$ & $.280^{\star \star}$ & $.220^{*}$ & $.324^{\star \star}$ \\
\hline 2008 & -.030 & $.506^{* *}$ & $-.571^{\star \star}$ & $.313^{*}$ & .227 & $.376^{\star}$ \\
\hline Constant & $1.389^{* \star \star}$ & $1.628^{* * *}$ & $1.147^{\star \star *}$ & $1.542^{* \star *}$ & $1.690^{\star \star * *}$ & $1.570^{* \star *}$ \\
\hline R-squared & .284 & .119 & .115 & .216 & .219 & .189 \\
\hline F-statistic & $10.93^{\star \star \star}$ & & & & & \\
\hline Wald $x^{2}$ & & $62.32^{\star \star * *}$ & $75.44^{\star \star \star}$ & $73.74^{\star \star \star}$ & $85.86^{\star \star \star}$ & $68.42^{\star \star \star}$ \\
\hline Observations & 255 & 255 & 255 & 255 & 255 & 255 \\
\hline \multicolumn{7}{|c|}{$\begin{array}{l}{ }^{*} p<0.10,{ }^{* *} p<0.05,{ }^{* * *} p<0.01 \text { for robust standard errors } \\
\text { Notes: values show estimated coefficient for ELF-E fractionalization index; }{ }^{a} \text { instruments for central } \\
\text { government expenditure using log population; }{ }^{b} \text { instruments for central government expenditure using } \\
\text { distance from district capital to Lusaka; }{ }^{c} \text { instruments for central government expenditure using log } \\
\text { population and distance from district capital to Lusaka. }\end{array}$} \\
\hline
\end{tabular}

Table D 21: Per capita expenditure_primary school enrolment

\begin{tabular}{|c|c|c|c|c|c|c|}
\hline Method & OLS & $2 S L S^{a}$ & $2 \mathrm{SLS}^{b}$ & $2 S L S^{c}$ & $\mathrm{GMM}^{c}$ & $\operatorname{LIML}^{c}$ \\
\hline ELF-E & $.289^{\star * \star}$ & $.306^{\star \star \star}$ & $280^{\star * *}$ & $.305^{\star \star \star *}$ & $.299^{* \star *}$ & $.305^{\star *+x}$ \\
\hline Area $(1000 \mathrm{~km} 2)$ & $.003^{\star *}$ & $.003^{\star \star \star}$ & $.003^{* *}$ & $.003^{\star \star \star *}$ & $.003^{\star \star \star *}$ & $.003^{\star \star \star}$ \\
\hline Poverty & $-.185^{\star \star \star}$ & $-.178^{\star *}$ & $-.189^{\star \star \star}$ & $-.179^{* *}$ & $-.181^{\star \star \star}$ & $-.179^{\star \star}$ \\
\hline Expenditure p.c. & $1.471^{\star \star \star}$ & $2.281^{\star * \star}$ & 1.024 & $2.233^{\star \star \star *}$ & $2.251^{* \star \star}$ & $2.235^{\star \star \star}$ \\
\hline Rural & $.061^{\star \star \star}$ & $.043^{\star *}$ & .071 & $.044^{\star *}$ & $.043^{* *}$ & $.044^{\star \star}$ \\
\hline 2005 & $.320^{\star * \star *}$ & $316^{* \star * *}$ & $323^{* \star * *}$ & $.316^{\star * \star}$ & $316^{* * * *}$ & $.316^{\star \star \star}$ \\
\hline 2006 & $.257^{\star \star \star *}$ & $227^{* \star \star x}$ & $.273^{\text {t*t }}$ & $.229^{\star \star * *}$ & $.228^{*+*}$ & $.229^{\star \star \star}$ \\
\hline 2007 & $.385^{\star \star *}$ & $.357^{\star \star \star}$ & $.401^{* \star * *}$ & $.358^{\star \star *}$ & $.359^{\star \star \star *}$ & $.358^{\star \star \star}$ \\
\hline 2008 & $.274^{\star \star \star}$ & $.203^{\star \star \star}$ & $.313^{*}$ & $.207^{\star \star \star *}$ & $.206^{\star \star \star *}$ & $.207^{\star \star \star}$ \\
\hline 2009 & $.260^{\star \star \star}$ & $.182^{\star \star \star}$ & $.303^{*}$ & $.187^{\star \star \star *}$ & $.186^{\star \star \star *}$ & $.187^{\star \star \star}$ \\
\hline Constant & $.807^{\star \star \star}$ & $.768^{\star \star \star}$ & $.828^{\star \star \star}$ & $.770^{\star \star \star}$ & $.774^{\star \star \star *}$ & $.770^{\star \star \star}$ \\
\hline R-squared & 509 & .490 & .503 & 492 & .491 & .492 \\
\hline F-statistic & $48.42^{\star \star \star}$ & & & & & \\
\hline Wald $x^{2}$ & & $460.77^{\star \star \star}$ & $464.87^{\star \star \star}$ & $461.58^{\star \star \star}$ & $462.19^{\star \star \star}$ & $461.47^{\star \star \star}$ \\
\hline Observations & 408 & 408 & 408 & 408 & 408 & 408 \\
\hline
\end{tabular}

${ }^{*} p<0.10,{ }^{* *} p<0.05,{ }^{* * *} p<0.01$ for robust standard errors

Notes: values show estimated coefficient for ELF-E fractionalization index; ${ }^{a}$ instruments for central government expenditure using log population; ${ }^{b}$ instruments for central government expenditure using distance from district capital to Lusaka; ${ }^{c}$ instruments for central government expenditure using log population and distance from district capital to Lusaka. 
Table D 22: Per capita expenditure-lower secondary school enrolment

\begin{tabular}{|c|c|c|c|c|c|c|}
\hline Method & OLS & $2 S L S^{a}$ & $2 S L S^{b}$ & $2 S L S^{c}$ & $\mathrm{GMM}^{c}$ & LIML $^{c}$ \\
\hline ELF-E & $.074^{*}$ & $.091^{\star \star}$ & $.144^{\star}$ & $.093^{\star \star}$ & $.087^{\star \star}$ & $.093^{\star \star}$ \\
\hline Area (1000 km2) & $.003^{\star \star \star}$ & $.003^{\star \star \star}$ & $.004^{* *}$ & $.003^{\star \star \star}$ & $.003^{\star \star \star}$ & $.003^{\star \star \star}$ \\
\hline Poverty & $-.697^{\star \star \star}$ & $-.690^{\star * \star}$ & $-.668^{\star \star \star}$ & $-.689^{\star \star \star}$ & $-.713^{\star \star \star}$ & $-.689^{\star \star \star}$ \\
\hline Expenditure p.c. & $1.475^{\star \star \star}$ & $2.258^{\star \star \star}$ & $4.823^{\star}$ & $2.356^{\star \star \star}$ & $2.257^{\star \star \star}$ & $2.364^{\star \star \star}$ \\
\hline Rural & $-.172^{\star \star \star}$ & $-.189^{\star \star \star}$ & $-.245^{\star \star \star}$ & $-.191^{\star \star \star}$ & $-.183^{\star \star \star}$ & $-.191^{\star \star *}$ \\
\hline 2005 & $.390^{\star \star \star}$ & $.385^{\star \star \star}$ & $.372^{\star \star \star}$ & $.385^{\star \star \star}$ & $.386^{\star \star \star}$ & $.385^{\star \star \star}$ \\
\hline 2006 & $.323^{\star \star \star}$ & $.295^{\star \star \star}$ & $.201^{\star *}$ & $.291^{\star \star \star}$ & $.295^{\star \star \star}$ & $.291^{\star \star \star}$ \\
\hline 2007 & $.189^{\star \star \star}$ & $.161^{\star \star \star}$ & .070 & $.158^{\star \star \star}$ & $.159^{\star \star \star}$ & $.157^{\star \star \star}$ \\
\hline 2008 & $.098^{\star \star *}$ & .029 & -.196 & .021 & .026 & .020 \\
\hline 2009 & $.171^{\star \star \star}$ & $.096^{\star *}$ & -.151 & $.086^{*}$ & $.095^{* \star}$ & $.086^{\star}$ \\
\hline Constant & $.788^{\star \star \star}$ & $.750^{\star \star \star}$ & $.628^{\star \star \star}$ & $.746^{\star \star \star}$ & $.764^{\star \star \star}$ & $.745^{\star \star \star}$ \\
\hline R-squared & .611 & .595 & .328 & .591 & .595 & .591 \\
\hline F-statistic & $69.44^{\star \star \star}$ & & & & & \\
\hline Wald $x^{2}$ & & $747.83^{\star * \star}$ & $549.22^{\star \star \star}$ & $756.13^{\star \star \star}$ & $761.05^{* \star *}$ & $755.83^{* * *}$ \\
\hline Observations & 408 & 408 & 408 & 408 & 408 & 408 \\
\hline
\end{tabular}

${ }^{*} p<0.10,{ }^{* *} p<0.05,{ }^{* * *} p<0.01$ for robust standard errors

Notes: values show estimated coefficient for ELF-E fractionalization index; ${ }^{a}$ instruments for central government expenditure using log population; ${ }^{b}$ instruments for central government expenditure using distance from district capital to Lusaka; ${ }^{c}$ instruments for central government expenditure using log population and distance from district capital to Lusaka.

Table D 23: Per capita expenditure-teacher pupil ratio 2008

\begin{tabular}{|c|c|c|c|c|c|c|}
\hline Method & OLS & $2 S L S^{a}$ & $2 S L S^{b}$ & $2 S L S^{c}$ & $\mathrm{GMM}^{c}$ & LIML $^{c}$ \\
\hline ELF-E & .002 & .001 & .005 & .002 & .002 & .002 \\
\hline Area (1000 km2) & .000 & -.000 & .000 & .000 & .000 & .000 \\
\hline Poverty & $-.013^{\star \star \star}$ & $-.013^{\star \star \star}$ & $-.016^{\star *}$ & $-.013^{\star \star \star}$ & $-.013^{\star \star \star}$ & $-.013^{\star \star \star}$ \\
\hline Expenditure p.c. & $.036^{\star \star \star}$ & $.031^{\star \star \star}$ & .203 & $.036^{\star \star \star}$ & $.037^{\star \star \star}$ & $.036^{\star \star \star}$ \\
\hline Rural & $-.003^{\star \star \star}$ & $-.003^{\star \star \star}$ & -.011 & $-.003^{\star \star \star}$ & $-.003^{\star \star \star}$ & $-.003^{\star \star \star}$ \\
\hline Constant & $.028^{\star \star \star}$ & $.029^{\star \star \star}$ & .009 & $.028^{\star \star \star}$ & $.027^{\star \star \star}$ & $.028^{\star \star \star}$ \\
\hline $\begin{array}{l}\text { R-squared } \\
\text { F-statistic }\end{array}$ & $\begin{array}{c}.538 \\
14.78^{\star \star \star}\end{array}$ & .535 & . & .538 & .537 & .538 \\
\hline Wald $x^{2}$ & & $74.42^{\star \star \star}$ & $12.67^{\star \star}$ & $84.51^{\star \star \star}$ & $82.11^{\star \star \star}$ & $81.58^{\star \star \star}$ \\
\hline Observations & 68 & 68 & 68 & 68 & 68 & 68 \\
\hline
\end{tabular}

${ }^{*} p<0.10,{ }^{* *} p<0.05,{ }^{* \star *} p<0.01$ for robust standard errors

Notes: values show estimated coefficient for ELF-E fractionalization index; $a$ instruments for central government expenditure using log population; ${ }^{b}$ instruments for central government expenditure using distance from district capital to Lusaka; ${ }^{c}$ instruments for central government expenditure using log population and distance from district capital to Lusaka. 
Table D 24: Per capita expenditure-basic school teacher pupil ratio 2009

\begin{tabular}{|c|c|c|c|c|c|c|}
\hline Method & OLS & $2 S L S^{a}$ & $2 S L S^{b}$ & $2 S L S^{c}$ & $\mathrm{GMM}^{c}$ & LIML $^{c}$ \\
\hline ELF-E & $.005^{* * *}$ & $.006^{\star \star \star}$ & .026 & $.006^{\star \star \star}$ & $.006^{\star \star \star}$ & $.007^{\star \star \star}$ \\
\hline Area (1000 km2) & -.000 & $-.000^{\star}$ & -.000 & -.000 & -.000 & -.000 \\
\hline Poverty & $-.016^{\star \star \star}$ & $-.016^{\star \star \star}$ & -.031 & $-.017^{\star \star \star}$ & $-.017^{\star \star \star}$ & $-.017^{\star \star \star}$ \\
\hline Expenditure p.c. & $.032^{\star \star \star}$ & $.051^{\star \star \star}$ & .394 & $.055^{\star \star \star}$ & $.054^{\star \star \star}$ & $.058^{\star \star \star}$ \\
\hline Rural & $-.002^{* *}$ & $-.003^{\star \star}$ & -.011 & $-.003^{\star \star \star}$ & $-.003^{\star \star \star}$ & $-.003^{\star \star \star}$ \\
\hline Constant & $.027^{\star \star *}$ & $.025^{\star \star \star}$ & -.014 & $.024^{\star \star \star}$ & $.024^{\star \star \star}$ & $.024^{\star \star \star}$ \\
\hline $\begin{array}{l}\text { R-squared } \\
\text { F-statistic }\end{array}$ & $\begin{array}{c}.589 \\
15.78^{\star \star \star}\end{array}$ & .545 & . & .527 & .529 & .509 \\
\hline Wald $x^{2}$ & & $111.88^{\star \star \star}$ & 5.81 & $113.42^{\star \star \star}$ & $112.61^{\star \star \star}$ & $109.88^{\star \star \star}$ \\
\hline Observations & 68 & 68 & 68 & 68 & 68 & 68 \\
\hline
\end{tabular}

${ }^{*} p<0.10,{ }^{* *} p<0.05,{ }^{* * *} p<0.01$ for robust standard errors

Notes: values show estimated coefficient for ELF-E fractionalization index; a instruments for central government expenditure using log population; ${ }^{b}$ instruments for central government expenditure using distance from district capital to Lusaka; ${ }^{c}$ instruments for central government expenditure using log population and distance from district capital to Lusaka.

Table D 25: Per capita expenditure-number of schools 2008

\begin{tabular}{|c|c|c|c|c|c|c|}
\hline Method & OLS & $2 S L S^{a}$ & $2 S L S^{b}$ & $2 S L S^{c}$ & $\mathrm{GMM}^{c}$ & $\mathrm{LIML}^{c}$ \\
\hline ELF-E & 6.721 & .475 & 51.895 & 2.081 & 4.033 & .826 \\
\hline Area (1000 km2) & $2.067^{\star \star \star}$ & $1.592^{\star \star \star}$ & 5.503 & $1.714^{\star \star \star}$ & $1.709^{\star \star \star}$ & $1.619^{\star \star \star}$ \\
\hline Poverty & $52.718^{*}$ & $56.688^{*}$ & 23.996 & $55.668^{*}$ & $59.965^{\star \star}$ & $56.465^{\star}$ \\
\hline Expenditure p.c. & $-510.921^{\star * *}$ & $-801.132^{\star \star \star}$ & 1588.182 & $-726.537^{\star \star \star}$ & $-756.551^{\star \star *}$ & $-784.831^{\star \star \star}$ \\
\hline Rural & -22.915 & -9.847 & -117.435 & -13.206 & -8.659 & -10.581 \\
\hline Constant & $142.695^{\star * \star}$ & $176.269^{\star \star \star}$ & -100.147 & $167.640^{\star \star \star}$ & $163.639^{\star \star \star}$ & $174.384^{\star \star \star}$ \\
\hline R-squared & .543 & .448 & . & .491 & .474 & .459 \\
\hline F-statistic & $12.72^{\star \star \star}$ & & & & & \\
\hline Wald $x^{2}$ & & $55.45^{\star * \star}$ & 6.39 & $57.74^{\star * \star}$ & $58.30^{\star \star \star}$ & $52.40^{\star \star \star}$ \\
\hline Observations & 68 & 68 & 68 & 68 & 68 & 68 \\
\hline
\end{tabular}

${ }^{*} p<0.10,{ }^{* *} p<0.05,{ }^{* \star *} p<0.01$ for robust standard errors

Notes: values show estimated coefficient for ELF-E fractionalization index; a instruments for central government expenditure using log population; ${ }^{b}$ instruments for central government expenditure using distance from district capital to Lusaka; ${ }^{c}$ instruments for central government expenditure using log population and distance from district capital to Lusaka.

Table D 26: Per capita expenditure-number of teachers 2008

\begin{tabular}{|c|c|c|c|c|c|c|}
\hline Method & OLS & $2 S L S^{a}$ & $2 S L S^{b}$ & $2 S_{L}{ }^{c}$ & $\mathrm{GMM}^{\mathrm{c}}$ & LIML $^{c}$ \\
\hline ELF-E & $322.728^{*}$ & 263.745 & 881.182 & 283.022 & 270.103 & 262.233 \\
\hline Area $(1000 \mathrm{~km} 2)$ & 4.315 & -.172 & 46.792 & 1.295 & 2.976 & -.287 \\
\hline Poverty & -437.271 & -399.770 & -792.338 & -412.026 & $-572.357^{*}$ & -398.808 \\
\hline Expenditure p.c. & $-3700.031^{\star \star \star}$ & $-6440.809^{\star \star \star}$ & 22249.786 & $-5545.076^{\star \star \star}$ & $-5035.234^{\star \star \star}$ & $-6511.074^{\star \star \star}$ \\
\hline Rural & $-490.687^{\star \star \star}$ & $-367.272^{\star \star}$ & -1659.183 & $-407.606^{\star \star \star}$ & $-380.610^{\star \star}$ & $-364.108^{\star \star}$ \\
\hline Constant & $1960.821^{\star \star \star}$ & $2277.897^{\star \star \star}$ & -1041.276 & $2174.271^{\star \star *}$ & $2183.636^{\star \star *}$ & $2286.026^{\star * *}$ \\
\hline R-squared & .593 & .509 & & .555 & .571 & .505 \\
\hline F-statistic & $15.67^{\star \star \star}$ & & & & & \\
\hline Wald $x^{2}$ & & $60.38^{\star \star \star}$ & 7.77 & $65.29^{\star \star \star}$ & $70.54^{\star \star \star}$ & $56.68^{\star \star *}$ \\
\hline Observations & 68 & 68 & 68 & 68 & 68 & 68 \\
\hline
\end{tabular}

${ }^{*} p<0.10,{ }^{* *} p<0.05,{ }^{* \star *} p<0.01$ for robust standard errors

Notes: values show estimated coefficient for ELF-E fractionalization index; ${ }^{a}$ instruments for central government expenditure using log population; ${ }^{b}$ instruments for central government expenditure using distance from district capital to Lusaka; ${ }^{c}$ instruments for central government expenditure using log population and distance from district capital to Lusaka. 
Table D 27: Per capita expenditure_number of basic schools 2009

\begin{tabular}{|c|c|c|c|c|c|c|}
\hline Method & OLS & $2 S L S^{a}$ & $2 S L S^{b}$ & $2 S L S^{c}$ & $\mathrm{GMM}^{\mathrm{c}}$ & LIML $^{c}$ \\
\hline ELF-E & -1.290 & -60.753 & 261.131 & -57.219 & $-69.002^{*}$ & -61.785 \\
\hline Area (1000 km2) & $2.852^{\star \star \star}$ & $2.932^{\star \star \star}$ & 2.497 & $2.928^{\star \star \star}$ & $2.888^{\star \star \star}$ & $2.934^{\star \star \star}$ \\
\hline Poverty & $64.654^{*}$ & $109.066^{\star *}$ & -131.342 & $106.426^{* \star}$ & $111.211^{* *}$ & $109.836^{\star *}$ \\
\hline Expenditure p.c. & $-276.456^{\star \star}$ & $-1286.929^{\star \star \star}$ & 4182.957 & $-1226.874^{\star \star \star}$ & $-1250.468^{\star \star \star}$ & $-1304.458^{\star \star \star}$ \\
\hline Rural & $-37.160^{\star \star}$ & -12.703 & -145.097 & -14.156 & -14.986 & -12.279 \\
\hline Constant & $107.376^{\star \star \star}$ & $220.598^{\star \star \star}$ & -392.294 & $213.869^{\star \star \star}$ & $217.238^{\star \star \star}$ & $222.562^{\star \star \star}$ \\
\hline R-squared & .309 & & & & 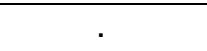 & . \\
\hline F-statistic & $9.03^{\star \star *}$ & & & & & \\
\hline Wald $x^{2}$ & & $23.54^{\star \star \star}$ & 1.71 & $24.00^{\star \star \star}$ & $25.26^{\star \star \star}$ & $21.89^{\star \star \star}$ \\
\hline Observations & 68 & 68 & 68 & 68 & 68 & 68 \\
\hline
\end{tabular}

${ }^{*} p<0.10,{ }^{* *} p<0.05,{ }^{* * *} p<0.01$ for robust standard errors

Notes: values show estimated coefficient for ELF-E fractionalization index; ${ }^{a}$ instruments for central government expenditure using log population; ${ }^{b}$ instruments for central government expenditure using distance from district capital to Lusaka; ${ }^{c}$ instruments for central government expenditure using log population and distance from district capital to Lusaka.

Table D 28: Per capita expenditure-maternal mortality

\begin{tabular}{|c|c|c|c|c|c|c|}
\hline Method & OLS & $2 S L S^{a}$ & $2 S L S^{b}$ & $2 S L S^{c}$ & $\mathrm{GMM}^{c}$ & LIML $^{c}$ \\
\hline ELF-E & -51.522 & -95.093 & -90.502 & -91.348 & -89.690 & -91.371 \\
\hline Area $(1000 \mathrm{~km} 2)$ & -.833 & 1.523 & 1.274 & 1.320 & 1.335 & 1.321 \\
\hline Poverty & $477.885^{*}$ & $700.161^{*}$ & $676.741^{\star *}$ & $681.060^{\star *}$ & $683.738^{\star *}$ & $681.175^{\star \star}$ \\
\hline Expenditure p.c. & 809.812 & $-2.49 e+04$ & $-2.22 \mathrm{e}+04^{\star \star}$ & $-2.27 e+04^{\star \star \star}$ & $-2.27 e+04^{\star \star *}$ & $-2.27 e+04^{* \star *}$ \\
\hline Rural & -51.859 & -722.552 & $-651.886^{\star \star}$ & $-664.918^{\star \star \star}$ & $-663.838^{\star \star \star}$ & $-665.267^{\star \star \star}$ \\
\hline 2005 & -33.197 & -10.166 & -12.592 & -12.145 & -12.208 & -12.133 \\
\hline 2006 & -29.104 & 453.735 & $402.861^{\star *}$ & $412.244^{\star *}$ & $412.977^{\star *}$ & $412.494^{* *}$ \\
\hline 2007 & -72.519 & 680.046 & $600.753^{\star *}$ & $615.376^{\star \star \star}$ & $615.775^{\star \star \star}$ & $615.767^{\star \star \star}$ \\
\hline 2008 & 38.230 & 1131.109 & $1015.959^{\star *}$ & $1037.195^{\star \star \star}$ & $1040.875^{\star \star \star}$ & $1037.763^{\star \star \star}$ \\
\hline Constant & 6.544 & 536.682 & $480.824^{*}$ & $491.126^{\star}$ & $487.468^{*}$ & $491.401^{*}$ \\
\hline R-squared & .034 & & r & . & 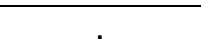 & \\
\hline F-statistic & $3.38^{\star \star \star}$ & & & & & \\
\hline Wald $x^{2}$ & & 6.72 & 11.51 & 12.77 & 12.74 & 12.76 \\
\hline Observations & 320 & 320 & 320 & 320 & 320 & 320 \\
\hline
\end{tabular}

${ }^{*} p<0.10,{ }^{* \star} p<0.05,{ }^{* \star *} p<0.01$ for robust standard errors

Notes: values show estimated coefficient for ELF-E fractionalization index; ${ }^{a}$ instruments for central government expenditure using log population; ${ }^{b}$ instruments for central government expenditure using distance from district capital to Lusaka; ${ }^{c}$ instruments for central government expenditure using log population and distance from district capital to Lusaka. 
Table D 29: Per capita expenditure-under 5 mortality

\begin{tabular}{|c|c|c|c|c|c|c|}
\hline Method & OLS & $2 S L S^{a}$ & $2 S L S^{b}$ & $2 S L S^{c}$ & $\mathrm{GMM}^{c}$ & LIML $^{c}$ \\
\hline ELF-E & -6.898 & -8.568 & -1.878 & -3.135 & -10.389 & -2.459 \\
\hline Area (1000 km2) & -.317 & -.253 & -.508 & -.460 & $-.585^{\star}$ & -.486 \\
\hline Poverty & $34.155^{\star *}$ & $41.664^{*}$ & 11.582 & 17.235 & 12.832 & 14.194 \\
\hline Expenditure p.c. & 88.500 & -788.071 & $2723.882^{\star * \star}$ & $2063.943^{* \star *}$ & $2276.611^{\text {** }}$ & $2418.929^{* *}$ \\
\hline Rural & 4.516 & -18.180 & $72.749^{\star \star}$ & $55.663^{\star \star}$ & $61.498^{\star \star}$ & $64.854^{\star \star}$ \\
\hline 2005 & 1.257 & 1.994 & -.959 & -.404 & .310 & -.702 \\
\hline 2006 & -1.500 & 14.872 & $-50.722^{\star \star \star}$ & $-38.396^{* *}$ & $-44.544^{\star \star \star}$ & $-45.026^{\star *}$ \\
\hline 2007 & $-16.184^{\star *}$ & 9.279 & $-92.735^{\star \star \star}$ & $-73.565^{\star \star \star}$ & $-79.641^{\star \star \star}$ & $-83.877^{\star \star \star}$ \\
\hline 2008 & $-30.569^{\star \star \star}$ & 7.190 & $-144.093^{\star \star *}$ & $-115.665^{\star \star \star}$ & $-123.140^{\star \star \star}$ & $-130.957^{\star * \star}$ \\
\hline Constant & $43.696^{\star \star \star}$ & 61.940 & -11.155 & 2.580 & 2.953 & -4.808 \\
\hline R-squared & .128 & .005 & 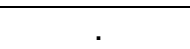 & . & . & 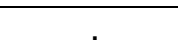 \\
\hline F-statistic & $7.91^{* \star *}$ & & & & & \\
\hline Wald $x^{2}$ & & $59.46^{\star \star \star}$ & $36.89^{\star \star \star}$ & $46.15^{\star \star \star}$ & $44.16^{\star \star \star}$ & $39.54^{\star \star \star}$ \\
\hline Observations & 329 & 329 & 329 & 329 & 329 & 329 \\
\hline \multicolumn{7}{|c|}{$\begin{array}{l}{ }^{*} p<0.10,{ }^{* *} p<0.05,{ }^{* *} p<0.01 \text { for robust standard errors } \\
\text { Notes: values show estimated coefficient for ELF-E fractionalization index; a instruments for central } \\
\text { government expenditure using log population; }{ }^{b} \text { instruments for central government expenditure using } \\
\text { distance from district capital to Lusaka; }{ }^{c} \text { instruments for central government expenditure using log } \\
\text { population and distance from district capital to Lusaka. }\end{array}$} \\
\hline
\end{tabular}

Table D 30: Per capita expenditure-total beds per 1000

\begin{tabular}{|c|c|c|c|c|c|c|}
\hline Method & OLS & $2 S L S^{a}$ & $2 S L S^{b}$ & $2 S L S^{c}$ & $\mathrm{GMM}^{c}$ & LIML $^{c}$ \\
\hline ELF-E & $-1.554^{\star \star \star}$ & -.969 & $-1.376^{\star \star}$ & $-1.299^{\star}$ & $-1.574^{\star \star}$ & -1.249 \\
\hline Area $(1000 \mathrm{~km} 2)$ & .004 & -.018 & -.003 & -.006 & .001 & -.008 \\
\hline Poverty & -.123 & -2.754 & -.925 & -1.268 & -.728 & -1.495 \\
\hline Expenditure p.c. & $14.188^{\star \star}$ & 321.363 & $107.805^{\star \star \star}$ & $147.935^{\star \star \star}$ & $120.481^{\star \star \star}$ & $174.353^{\star \star \star}$ \\
\hline Rural & -.513 & 7.440 & $1.911^{\star}$ & $2.950^{\star \star}$ & 1.791 & $3.634^{*}$ \\
\hline 2005 & -.109 & -.367 & -.188 & -.221 & -.197 & -.243 \\
\hline 2006 & -.346 & -6.083 & $-2.094^{\star \star \star}$ & $-2.844^{\star \star \star}$ & $-2.389^{\star \star \star}$ & $-3.337^{\star \star \star}$ \\
\hline 2007 & $-.504^{*}$ & -9.427 & $-3.223^{\star \star \star}$ & $-4.389^{\star \star \star}$ & $-3.628^{\star \star \star}$ & $-5.157^{\star \star \star}$ \\
\hline 2008 & -.518 & -13.751 & $-4.551^{\star \star \star}$ & $-6.280^{\star \star *}$ & $-5.071^{\star \star \star}$ & $-7.418^{\star \star \star}$ \\
\hline Constant & $3.195^{\star \star \star}$ & -3.198 & 1.247 & .412 & 1.160 & -.138 \\
\hline R-squared & .070 & & 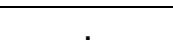 & . & 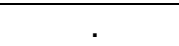 & 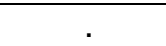 \\
\hline F-statistic & $2.38^{\star *}$ & & & & & \\
\hline Wald $x^{2}$ & & 5.09 & $28.55^{\star \star \star}$ & $27.74^{\star \star \star}$ & $35.58^{\star \star \star}$ & $20.85^{\star \star}$ \\
\hline Observations & 329 & 329 & 329 & 329 & 329 & 329 \\
\hline \multicolumn{7}{|c|}{$\begin{array}{l}{ }^{*} p<0.10,{ }^{* \star} p<0.05,{ }^{* \star} p<0.01 \text { for robust standard errors } \\
\text { Notes: values show estimated coefficient for ELF-E fractionalization index; a instruments for central } \\
\text { government expenditure using log population; }{ }^{b} \text { instruments for central government expenditure using } \\
\text { distance from district capital to Lusaka; }{ }^{c} \text { instruments for central government expenditure using log } \\
\text { population and distance from district capital to Lusaka. }\end{array}$} \\
\hline
\end{tabular}


Table D 31: Per capita expenditure-BCG immunization rate

\begin{tabular}{|c|c|c|c|c|c|c|}
\hline Method & OLS & $2 S L S^{a}$ & $2 S L S^{b}$ & $2 S L S^{c}$ & $\mathrm{GMM}^{c}$ & $\operatorname{LIML}^{c}$ \\
\hline ELF-E & $.195^{\star * \star}$ & .142 & $.217^{* \star *}$ & $.203^{\star \star \star}$ & $.228^{* \star *}$ & $.222^{* \star}$ \\
\hline Area $(1000$ km2) & .002 & .004 & .001 & .002 & .001 & .001 \\
\hline Poverty & $.404^{\star \star \star}$ & $.642^{* *}$ & $.305^{* \star *}$ & $.369^{\star \star \star}$ & $.338^{\star \star \star}$ & .282 \\
\hline Expenditure p.c. & .270 & -27.570 & $11.781^{\star \star}$ & 4.386 & $9.081^{*}$ & 14.523 \\
\hline Rural & .021 & -.700 & $.319^{* \star}$ & .128 & $.250^{*}$ & .390 \\
\hline 2005 & -.027 & -.003 & -.036 & -.030 & -.025 & -.039 \\
\hline 2006 & .002 & .522 & $-.213^{*}$ & -.074 & -.149 & -.264 \\
\hline 2007 & -.048 & .761 & $-.382^{\star \star}$ & -.167 & $-.295^{\star}$ & -.462 \\
\hline 2008 & .001 & 1.200 & $-.495^{\star \star}$ & -.176 & -.339 & -.613 \\
\hline Constant & $.848^{\star \star \star}$ & $1.427^{\star \star \star}$ & $.608^{\star \star \star}$ & $.762^{\star \star \star}$ & $.657^{\star \star \star}$ & .551 \\
\hline R-squared & .106 & . & . & .034 & . & . \\
\hline F-statistic & $5.47^{\star \star \star}$ & & & & & \\
\hline Wald $x^{2}$ & & $15.74^{*}$ & $32.58^{\star \star \star}$ & $46.36^{\star \star \star}$ & $39.75^{\star \star \star}$ & $26.95^{\star \star \star}$ \\
\hline Observations & 329 & 329 & 329 & 329 & 329 & 329 \\
\hline \multicolumn{7}{|c|}{$\begin{array}{l}{ }^{*} p<0.10,{ }^{* *} p<0.05,{ }^{* * *} p<0.01 \text { for robust standard errors } \\
\text { Notes: values show estimated coefficient for ELF-E fractionalization index; a instruments for central } \\
\text { government expenditure using log population; }{ }^{b} \text { instruments for central government expenditure using } \\
\text { distance from district capital to Lusaka; }{ }^{c} \text { instruments for central government expenditure using log } \\
\text { population and distance from district capital to Lusaka. }\end{array}$} \\
\hline
\end{tabular}

Table D 32: Per capita expenditure-DPT3 immunization rate

\begin{tabular}{|c|c|c|c|c|c|c|}
\hline Method & OLS & $2 S L S^{a}$ & $2 S L S^{b}$ & $2 S L S^{c}$ & $\mathrm{GMM}^{c}$ & LIML $^{c}$ \\
\hline ELF-E & $.239^{\star \star \star}$ & .166 & $.288^{\star \star \star}$ & $.265^{\star \star \star}$ & $.334^{\star \star \star}$ & $.314^{\star}$ \\
\hline Area $(1000$ km2) & $.003^{\star}$ & .006 & .001 & .002 & .000 & -.000 \\
\hline Poverty & $.193^{\star \star}$ & .520 & -.026 & .076 & .028 & -.147 \\
\hline Expenditure p.c. & -.710 & -38.894 & $24.897^{\star \star \star}$ & $12.910^{\star \star}$ & $18.352^{\star *}$ & 38.985 \\
\hline Rural & .058 & -.931 & $.721^{\star \star \star}$ & $.410^{\star \star}$ & $.582^{\star \star \star}$ & 1.085 \\
\hline 2005 & .011 & .043 & -.011 & -.001 & -.002 & -.023 \\
\hline 2006 & -.070 & .643 & $-.548^{\star \star \star}$ & $-.324^{\star \star \star}$ & $-.420^{\star \star \star}$ & -.811 \\
\hline 2007 & $-.148^{\star \star \star}$ & .962 & $-.891^{\star \star \star}$ & $-.543^{\star \star \star}$ & $-.692^{\star \star \star}$ & -1.301 \\
\hline 2008 & -.049 & 1.596 & $-1.152^{\star \star \star}$ & $-.636^{\star *}$ & $-.812^{\star \star \star}$ & -1.759 \\
\hline Constant & $.901^{\star \star \star}$ & $1.695^{\star \star \star}$ & .368 & $.617^{\star \star \star}$ & $.462^{\star \star}$ & .074 \\
\hline R-squared & .151 & . & . & . & . & . \\
\hline F-statistic & $7.62^{\star \star \star}$ & & & & & \\
\hline Wald $x^{2}$ & & $15.25^{\star}$ & $36.40^{\star \star \star}$ & $51.20^{\star \star \star}$ & $49.84^{\star \star \star}$ & $15.45^{*}$ \\
\hline Observations & 329 & 329 & 329 & 329 & 329 & 329 \\
\hline \multicolumn{7}{|c|}{$\begin{array}{l}{ }^{*} p<0.10,{ }^{* *} p<0.05,{ }^{* \star *} p<0.01 \text { for robust standard errors } \\
\text { Notes: values show estimated coefficient for ELF-E fractionalization index; a instruments for central } \\
\text { government expenditure using log population; }{ }^{b} \text { instruments for central government expenditure using } \\
\text { distance from district capital to Lusaka; }{ }^{c} \text { instruments for central government expenditure using log } \\
\text { population and distance from district capital to Lusaka. }\end{array}$} \\
\hline
\end{tabular}


Table D 33: Per capita expenditure-OPV3 immunization rate

\begin{tabular}{|c|c|c|c|c|c|c|}
\hline Method & OLS & $2 S L S^{a}$ & $2 S L S^{b}$ & $2 S L S^{c}$ & $\mathrm{GMM}^{c}$ & LIML $^{c}$ \\
\hline ELF-E & $.272^{\star \star \star}$ & .194 & $.325^{\star \star \star}$ & $.300^{* \star *}$ & $.341^{* \star *}$ & $.353^{\star}$ \\
\hline Area (1000 km2) & .000 & .003 & -.002 & -.001 & -.002 & -.003 \\
\hline Poverty & $.193^{\star \star}$ & .542 & -.046 & .065 & .004 & -.171 \\
\hline Expenditure p.c. & -.596 & -41.444 & $27.259^{\star \star \star}$ & $14.349^{\star *}$ & $19.444^{\star \star}$ & 41.889 \\
\hline Rural & .076 & -.981 & $.798^{\star \star \star}$ & $.463^{\star \star}$ & $.626^{\star \star \star}$ & 1.176 \\
\hline 2005 & $-.138^{\star \star \star}$ & -.103 & $-.161^{*}$ & $-.150^{\star \star \star}$ & $-.143^{\star \star}$ & -.173 \\
\hline 2006 & $-.096^{\star}$ & .667 & $-.617^{\star \star \star}$ & $-.376^{\star \star \star}$ & $-.450^{\star \star \star}$ & -.890 \\
\hline 2007 & $-.227^{\star \star \star}$ & .960 & $-1.036^{\star \star \star}$ & $-.661^{\star \star \star}$ & $-.785^{\star \star \star}$ & -1.461 \\
\hline 2008 & -.075 & 1.684 & $-1.275^{\star \star \star}$ & $-.719^{\star \star}$ & $-.868^{\star \star \star}$ & -1.905 \\
\hline Constant & $.933^{\star \star \star}$ & $1.783^{\star \star}$ & .353 & $.622^{\star \star \star}$ & $.487^{\star \star}$ & .049 \\
\hline R-squared & .153 & . & . & . & . & . \\
\hline F-statistic & $6.53^{\star \star \star}$ & & & & & \\
\hline Wald $x^{2}$ & & 12.85 & $29.06^{\star * *}$ & $40.78^{\star \star \star}$ & $34.92^{\star \star \star}$ & 13.28 \\
\hline Observations & 329 & 329 & 329 & 329 & 329 & 329 \\
\hline \multicolumn{7}{|c|}{$\begin{array}{l}{ }^{*} p<0.10,{ }^{* *} p<0.05,{ }^{* * *} p<0.01 \text { for robust standard errors } \\
\text { Notes: values show estimated coefficient for ELF-E fractionalization index; a instruments for central } \\
\text { government expenditure using log population; }{ }^{b} \text { instruments for central government expenditure using } \\
\text { distance from district capital to Lusaka; }{ }^{c} \text { instruments for central government expenditure using log } \\
\text { population and distance from district capital to Lusaka. }\end{array}$} \\
\hline
\end{tabular}

Table D 34: Per capita expenditure-measles immunization rate

\begin{tabular}{|c|c|c|c|c|c|c|}
\hline Method & OLS & $2 S L S^{a}$ & $2 S L S^{b}$ & $2 S L S^{c}$ & $\mathrm{GMM}^{c}$ & $\mathrm{LIML}^{c}$ \\
\hline ELF-E & $.204^{\star \star \star}$ & .128 & $.224^{\star \star \star}$ & $.206^{\star \star \star}$ & $.208^{\star \star \star}$ & .443 \\
\hline Area (1000 km2) & -.000 & .002 & -.001 & -.001 & -.002 & -.010 \\
\hline Poverty & $.215^{\star \star}$ & .559 & .124 & $.206^{\star *}$ & $.197^{\star \star}$ & -.861 \\
\hline Expenditure p.c. & -.123 & -40.213 & $10.544^{\star *}$ & 1.006 & 3.628 & 125.490 \\
\hline Rural & .043 & -.995 & $.319^{\star \star}$ & .072 & .133 & 3.295 \\
\hline 2005 & .015 & .048 & .006 & .014 & .014 & -.091 \\
\hline 2006 & .041 & .790 & -.158 & .020 & -.029 & -2.305 \\
\hline 2007 & .045 & 1.210 & -.264 & .013 & -.064 & -3.603 \\
\hline 2008 & .036 & 1.763 & $-.424^{*}$ & -.013 & -.095 & -5.375 \\
\hline Constant & $.750^{\star \star *}$ & $1.584^{\star *}$ & $.528^{\star \star *}$ & $.726^{\star \star \star}$ & $.684^{* \star *}$ & -1.865 \\
\hline R-squared & .059 & 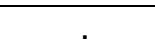 & 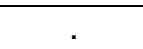 & .052 & 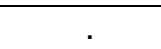 & \\
\hline F-statistic & $2.48^{\star \star \star}$ & & & & & \\
\hline Wald $x^{2}$ & & 5.83 & $20.29^{\star \star}$ & $23.19^{\star \star \star}$ & $22.35^{\star \star \star}$ & .46 \\
\hline Observations & 329 & 329 & 329 & 329 & 329 & 329 \\
\hline
\end{tabular}

${ }^{*} p<0.10,{ }^{* *} p<0.05,{ }^{* * *} p<0.01$ for robust standard errors

Notes: values show estimated coefficient for ELF-E fractionalization index; $a$ instruments for central government expenditure using log population; ${ }^{b}$ instruments for central government expenditure using distance from district capital to Lusaka; ${ }^{c}$ instruments for central government expenditure using log population and distance from district capital to Lusaka. 
Table D 35: Per capita expenditure-FIC immunization rate

\begin{tabular}{|c|c|c|c|c|c|c|}
\hline Method & OLS & $2 S L S^{a}$ & $2 S L S^{b}$ & $2 S L S^{c}$ & $\mathrm{GMM}^{c}$ & $\operatorname{LIML}^{c}$ \\
\hline ELF-E & $.365^{\star \star *}$ & $.327^{\star \star \star}$ & $.398^{* * *}$ & $.384^{\star \star \star}$ & $.418^{\star \star \star}$ & $.405^{\star \star \star}$ \\
\hline Area (1000 km2) & $-.003^{\star \star \star}$ & -.002 & $-.005^{\star \star}$ & $-.004^{\star \star}$ & $-.005^{\star \star \star}$ & -.005 \\
\hline Poverty & .034 & .204 & -.114 & -.054 & -.092 & -.149 \\
\hline Expenditure p.c. & .304 & -19.577 & $17.572^{\star \star \star}$ & $10.591^{\star *}$ & $14.590^{\star \star \star}$ & 21.668 \\
\hline Rural & .023 & -.492 & $.470^{\star \star \star}$ & $.289^{\star \star}$ & $.405^{\star \star \star}$ & .576 \\
\hline 2005 & .023 & .040 & .009 & .015 & .012 & .005 \\
\hline 2006 & $.067^{\star *}$ & .438 & $-.256^{\star \star}$ & -.125 & $-.197^{\star}$ & -.332 \\
\hline 2007 & .013 & .591 & $-.489^{\star \star \star}$ & $-.286^{\star \star}$ & $-.399^{\star \star \star}$ & -.608 \\
\hline 2008 & .074 & .930 & $-.670^{\star \star \star}$ & $-.370^{\star \star}$ & $-.507^{\star \star}$ & -.847 \\
\hline Constant & $.660^{\star \star \star}$ & $1.074^{\star \star \star}$ & $.301^{*}$ & $.446^{\star \star \star}$ & $.351^{\star *}$ & .216 \\
\hline $\begin{array}{l}\text { R-squared } \\
\text { F-statistic }\end{array}$ & $\begin{array}{c}.250 \\
10.74^{\star \star \star}\end{array}$ & . & . & . & . & . \\
\hline Wald $x^{2}$ & & $30.13^{\star \star \star}$ & $44.62^{\star \star \star}$ & $66.62^{\star \star \star}$ & $62.39^{\star \star \star}$ & $27.65^{\star \star \star}$ \\
\hline Observations & 329 & 329 & 329 & 329 & 329 & 329 \\
\hline \multicolumn{7}{|c|}{$\begin{array}{l}{ }^{*} p<0.10,{ }^{* *} p<0.05,{ }^{* * *} p<0.01 \text { for robust standard errors } \\
\text { Notes: values show estimated coefficient for ELF-E fractionalization index; a instruments for central } \\
\text { government expenditure using log population; }{ }^{b} \text { instruments for central government expenditure using } \\
\text { distance from district capital to Lusaka; }{ }^{c} \text { instruments for central government expenditure using log } \\
\text { population and distance from district capital to Lusaka. }\end{array}$} \\
\hline
\end{tabular}

Table D 36: Per capita expenditure-underweight5

\begin{tabular}{|c|c|c|c|c|c|c|}
\hline Method & OLS & $2 S L S^{a}$ & $2 S L S^{b}$ & $2 S L S^{c}$ & $\mathrm{GMM}^{c}$ & LIML $^{c}$ \\
\hline ELF-E & $-12.883^{\star \star \star}$ & $-13.152^{\star \star \star}$ & $-13.245^{\star \star \star}$ & $-13.228^{\star \star \star}$ & $-13.227^{\star \star \star}$ & $-13.228^{\star \star \star}$ \\
\hline Area $(1000 \mathrm{~km} 2)$ & -.017 & -.006 & -.003 & -.004 & -.002 & -.004 \\
\hline Poverty & $4.191^{\star *}$ & $5.399^{*}$ & $5.820^{\star \star}$ & $5.741^{\star *}$ & $5.800^{\star \star}$ & $5.744^{\star \star}$ \\
\hline Expenditure p.c. & $33.795^{*}$ & -107.173 & -156.322 & -147.087 & -150.366 & -147.489 \\
\hline Rural & $3.035^{\star \star \star}$ & -.614 & -1.887 & -1.648 & -1.776 & -1.658 \\
\hline 2005 & -.873 & -.755 & -.714 & -.721 & -.718 & -.721 \\
\hline 2006 & $-3.781^{\star \star \star}$ & -1.148 & -.230 & -.402 & -.345 & -.395 \\
\hline 2007 & $-8.288^{\star \star \star}$ & -4.193 & -2.766 & -3.034 & -2.947 & -3.022 \\
\hline 2008 & $-12.954^{\star \star \star}$ & -6.881 & -4.764 & -5.162 & -5.033 & -5.144 \\
\hline Constant & $17.076^{\star \star \star}$ & $20.010^{\star \star \star}$ & $21.033^{\star \star \star}$ & $20.841^{\star \star \star}$ & $20.897^{\star \star \star}$ & $20.849^{\star \star \star}$ \\
\hline R-squared & .605 & .528 & .465 & .478 & .474 & .478 \\
\hline F-statistic & $71.59^{\star \star \star}$ & & & & & \\
\hline Wald $x^{2}$ & & $523.90^{\star \star \star}$ & $446.66^{\star \star \star}$ & $459.59^{\star \star \star}$ & $455.93^{\star \star \star}$ & $458.98^{\star \star \star}$ \\
\hline Observations & 329 & 329 & 329 & 329 & 329 & 329 \\
\hline \multicolumn{7}{|c|}{$\begin{array}{l}{ }^{*} p<0.10,{ }^{* *} p<0.05,{ }^{* * *} p<0.01 \text { for robust standard errors } \\
\text { Notes: values show estimated coefficient for ELF-E fractionalization index; a instruments for central } \\
\text { government expenditure using log population; }{ }^{b} \text { instruments for central government expenditure using } \\
\text { distance from district capital to Lusaka; }{ }^{c} \text { instruments for central government expenditure using log } \\
\text { population and distance from district capital to Lusaka. }\end{array}$} \\
\hline
\end{tabular}


Table D 37: Per capita expenditure-HC_Staffpc

\begin{tabular}{|c|c|c|c|c|c|c|}
\hline Method & OLS & $2 S L S^{a}$ & $2 S L S^{b}$ & $2 S L S^{c}$ & $\mathrm{GMM}^{c}$ & $\operatorname{LIML}^{c}$ \\
\hline ELF-E & $2.604^{\star \star \star}$ & $3.373^{\star \star}$ & $3.049^{\star \star \star}$ & $3.110^{\star \star \star}$ & $3.013^{\star \star \star}$ & $3.132^{\star \star \star}$ \\
\hline Area (1000 km2) & $-.072^{\star \star \star}$ & $-.102^{\star \star}$ & $-.089^{\star \star \star}$ & $-.092^{\star \star \star}$ & $-.089^{\star * \star}$ & $-.092^{\star \star \star}$ \\
\hline Poverty & $-3.433^{\star \star \star}$ & $-6.894^{\star}$ & $-5.434^{\star \star \star}$ & $-5.708^{\star \star \star}$ & $-5.424^{\star \star \star}$ & $-5.810^{\star * \star}$ \\
\hline Expenditure p.c. & $23.393^{\star \star \star}$ & 427.424 & $256.962^{\star \star \star}$ & $288.994^{\star \star \star}$ & $275.331^{\star \star \star}$ & $300.902^{\star \star \star}$ \\
\hline Rural & $-.578^{\star}$ & 9.883 & $5.470^{\star \star}$ & $6.299^{\star \star}$ & $5.791^{\star \star}$ & $6.607^{\star \star}$ \\
\hline 2005 & .002 & -.338 & -.194 & -.221 & -.205 & -.231 \\
\hline 2006 & -.356 & -7.902 & $-4.719^{\star \star \star}$ & $-5.317^{\star \star \star}$ & $-5.093^{\star \star \star}$ & $-5.539^{\star \star \star}$ \\
\hline 2007 & $-.544^{*}$ & -12.280 & $-7.329^{\star \star \star}$ & $-8.259^{\star \star \star}$ & $-7.874^{\star \star \star}$ & $-8.605^{* * *}$ \\
\hline 2008 & $-1.321^{\star \star \star}$ & -18.726 & $-11.383^{\star \star \star}$ & $-12.763^{\star \star \star}$ & $-12.314^{\star \star \star}$ & $-13.276^{\star \star \star}$ \\
\hline Constant & $6.920^{\star \star \star}$ & -1.489 & 2.059 & 1.392 & 1.706 & 1.144 \\
\hline R-squared & .516 & . & . & . & 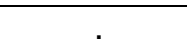 & . \\
\hline F-statistic & $57.18^{\star \star \star}$ & & & & & \\
\hline Wald $x^{2}$ & & 13.85 & $47.05^{\star \star \star}$ & $40.62^{\star \star \star}$ & $44.06^{\star \star *}$ & $37.50^{\star \star \star}$ \\
\hline Observations & 329 & 329 & 329 & 329 & 329 & 329 \\
\hline \multicolumn{7}{|c|}{$\begin{array}{l}{ }^{*} p<0.10,{ }^{* *} p<0.05,{ }^{* * *} p<0.01 \text { for robust standard errors } \\
\text { Notes: values show estimated coefficient for ELF-E fractionalization index; a instruments for central } \\
\text { government expenditure using log population; }{ }^{b} \text { instruments for central government expenditure using } \\
\text { distance from district capital to Lusaka; }{ }^{c} \text { instruments for central government expenditure using log } \\
\text { population and distance from district capital to Lusaka. }\end{array}$} \\
\hline
\end{tabular}

Table D 38: Per capita expenditure-Hosp_OPDStaffpc

\begin{tabular}{|c|c|c|c|c|c|c|}
\hline Method & OLS & $2 S L S^{a}$ & $2 S L^{b}$ & $2 S L S^{c}$ & $\mathrm{GMM}^{c}$ & $\operatorname{LIML}^{c}$ \\
\hline ELF-E & $.296^{*}$ & .342 & $.314^{*}$ & $.325^{*}$ & $.293^{*}$ & $.327^{\star}$ \\
\hline Area (1000 km2) & $-.010^{\star \star \star}$ & -.008 & $-.009^{\star \star}$ & $-.009^{\star *}$ & $-.008^{* \star}$ & $-.009^{\star \star}$ \\
\hline Poverty & $-.623^{\star \star \star}$ & $-1.095^{\star \star \star}$ & $-.809^{\star \star \star}$ & $-.923^{\star \star \star}$ & $-.916^{\star \star \star}$ & $-.942^{\star \star \star}$ \\
\hline Expenditure p.c. & $5.624^{\star \star}$ & $44.019^{\star}$ & $20.746^{\star *}$ & $29.989^{\star * \star}$ & $26.622^{\star \star \star}$ & $31.532^{\star \star \star}$ \\
\hline Rural & $-.305^{\star \star \star}$ & .548 & .031 & .236 & .137 & .270 \\
\hline 2005 & .002 & -.039 & -.014 & -.024 & -.027 & -.025 \\
\hline 2006 & -.070 & $-.824^{*}$ & $-.367^{*}$ & $-.549^{\star \star \star}$ & $-.495^{\star \star}$ & $-.579^{\star \star}$ \\
\hline 2007 & -.104 & $-1.304^{*}$ & $-.577^{\star \star}$ & $-.866^{\star \star \star}$ & $-.758^{\star \star \star}$ & $-.914^{\star \star \star}$ \\
\hline 2008 & $-.256^{\star \star}$ & $-2.081^{*}$ & $-.975^{\star \star}$ & $-1.414^{\star \star \star}$ & $-1.261^{\star \star \star}$ & $-1.488^{\star \star \star}$ \\
\hline Constant & $1.319^{\star \star \star}$ & .721 & $1.084^{\star \star \star}$ & $.940^{\star \star \star}$ & $1.036^{\star \star \star}$ & $.916^{\star \star \star}$ \\
\hline R-squared & .302 & 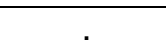 & .167 & . & .041 & 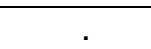 \\
\hline F-statistic & $12.47^{\star \star \star}$ & & & & & \\
\hline Wald $x^{2}$ & & $40.47^{\star \star \star}$ & $75.69^{\star \star \star}$ & $66.17^{\star \star \star}$ & $75.23^{\star \star \star}$ & $62.44^{\star \star \star}$ \\
\hline Observations & 255 & 255 & 255 & 255 & 255 & 255 \\
\hline \multicolumn{7}{|c|}{$\begin{array}{l}{ }^{*} p<0.10,{ }^{* *} p<0.05,{ }^{* * *} p<0.01 \text { for robust standard errors } \\
\text { Notes: values show estimated coefficient for ELF-E fractionalization index; a instruments for central } \\
\text { government expenditure using log population; }{ }^{b} \text { instruments for central government expenditure using } \\
\text { distance from district capital to Lusaka; }{ }^{c} \text { instruments for central government expenditure using log } \\
\text { population and distance from district capital to Lusaka. }\end{array}$} \\
\hline
\end{tabular}


Appendix E: Fractionalization and education and health outcomes: System-GMM estimates

Table E 1: System GMM education total expenditure-primary school enrolment 2004-2009

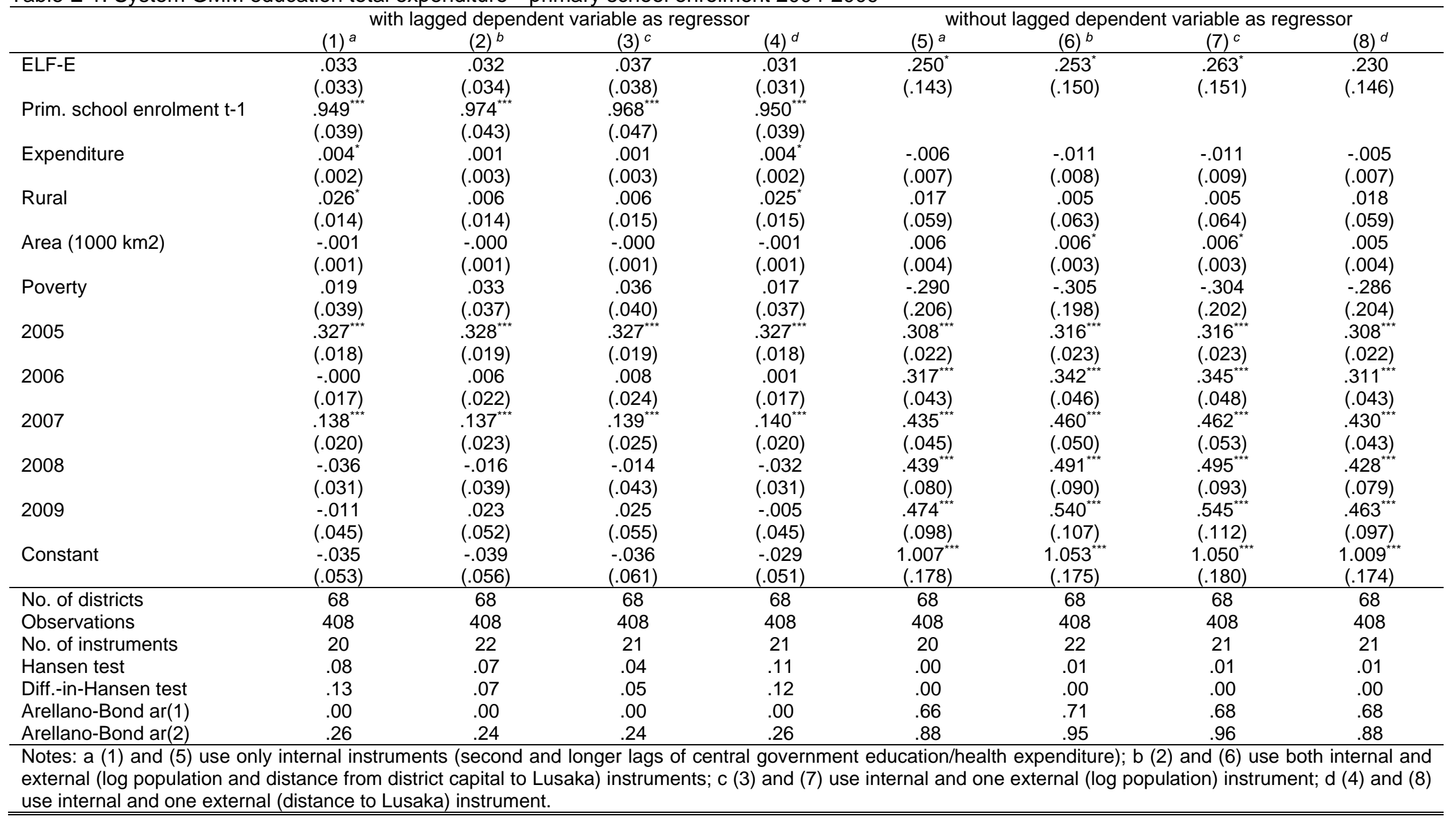


Table E 2: System GMM education total expenditure-lower secondary school enrolment 2004-2009

\begin{tabular}{|c|c|c|c|c|c|c|c|c|}
\hline & \multicolumn{4}{|c|}{ with lagged dependent variable as regressor } & \multicolumn{4}{|c|}{ without lagged dependent variable as regressor } \\
\hline & $(1)^{a}$ & $(2)^{b}$ & $(3)^{c}$ & $(4)^{d}$ & $(5)^{a}$ & $(6)^{b}$ & $(7)^{c}$ & $(8)^{d}$ \\
\hline ELF-E & $\begin{array}{c}-.004 \\
(.059)\end{array}$ & $\begin{array}{c}.007 \\
(.050)\end{array}$ & $\begin{array}{c}.011 \\
(.056)\end{array}$ & $\begin{array}{c}-.006 \\
(.060)\end{array}$ & $\begin{array}{c}.001 \\
(.105)\end{array}$ & $\begin{array}{c}.024 \\
(.101)\end{array}$ & $\begin{array}{c}.024 \\
(.101)\end{array}$ & $\begin{array}{l}-.016 \\
(.115)\end{array}$ \\
\hline lower sec. enrolment $\sim \mathrm{t}-1$ & $\begin{array}{l}.429^{* * *} \\
(.062)\end{array}$ & $\begin{array}{l}.562^{\star \star \star} \\
(.076)\end{array}$ & $\begin{array}{l}.517^{\star \star \star} \\
(.073)\end{array}$ & $\begin{array}{l}.442^{\star \star \star} \\
(.066)\end{array}$ & & & & \\
\hline Expenditure & $\begin{array}{c}.003 \\
(.004)\end{array}$ & $\begin{array}{c}-.002 \\
(.004)\end{array}$ & $\begin{array}{c}-.004 \\
(.005)\end{array}$ & $\begin{array}{c}.004 \\
(.004)\end{array}$ & $\begin{array}{c}.009 \\
(.005)\end{array}$ & $\begin{array}{c}-.003 \\
(.007)\end{array}$ & $\begin{array}{c}-.004 \\
(.008)\end{array}$ & $\begin{array}{l}.012^{*} \\
(.006)\end{array}$ \\
\hline Rural & $\begin{array}{l}-.058 \\
(.045)\end{array}$ & $\begin{array}{l}-.078^{\star} \\
(.040)\end{array}$ & $\begin{array}{l}-.088^{*} \\
(.045)\end{array}$ & $\begin{array}{c}-.053 \\
(.042)\end{array}$ & $\begin{array}{l}-.095 \\
(.069)\end{array}$ & $\begin{array}{l}-.148^{\star} \\
(.076)\end{array}$ & $\begin{array}{l}-.148^{*} \\
(.080)\end{array}$ & $\begin{array}{l}-.106^{\star} \\
(.063)\end{array}$ \\
\hline Area $(1000$ km2) & $\begin{array}{l}.003^{*} \\
(.002)\end{array}$ & $\begin{array}{l}.003^{\star *} \\
(.002)\end{array}$ & $\begin{array}{l}.003^{\star *} \\
(.002)\end{array}$ & $\begin{array}{c}.003 \\
(.002)\end{array}$ & $\begin{array}{c}.004 \\
(.003)\end{array}$ & $\begin{array}{l}.006^{* *} \\
(.003)\end{array}$ & $\begin{array}{l}.006^{\star \star} \\
(.003)\end{array}$ & $\begin{array}{c}.004 \\
(.003)\end{array}$ \\
\hline Poverty & $\begin{array}{c}-.438^{\star \star \star} \\
(.116)\end{array}$ & $\begin{array}{c}-.338^{\star \star \star} \\
(.108)\end{array}$ & $\begin{array}{c}-.370^{\star \star \star} \\
(.122)\end{array}$ & $\begin{array}{c}-.422^{\star \star \star} \\
(.105)\end{array}$ & $\begin{array}{c}-.763^{\star \star \star} \\
(.163)\end{array}$ & $\begin{array}{c}-.733^{\star \star \star} \\
(.168)\end{array}$ & $\begin{array}{c}-.745^{\star \star \star} \\
(.182)\end{array}$ & $\begin{array}{c}-.691^{\star \star} \\
(.150)\end{array}$ \\
\hline 2005 & $\begin{array}{l}.346^{\text {** }} \\
(.031)\end{array}$ & $\begin{array}{l}.361^{\star \star \star} \\
(.037)\end{array}$ & $\begin{array}{l}.365^{\star \star \star} \\
(.038)\end{array}$ & $\begin{array}{l}.346^{\star \star \star} \\
(.031)\end{array}$ & $\begin{array}{l}.355^{\star \star \star} \\
(.034)\end{array}$ & $\begin{array}{l}.373^{\star \star \star} \\
(.041)\end{array}$ & $\begin{array}{l}.376^{\star \star \star} \\
(.041)\end{array}$ & $\begin{array}{l}.352^{\star \star \star} \\
(.035)\end{array}$ \\
\hline 2006 & $\begin{array}{l}.165^{\star \star \star} \\
(.031)\end{array}$ & $\begin{array}{l}.149^{\star \star \star} \\
(.035)\end{array}$ & $\begin{array}{l}.172^{\star \star \star} \\
(.036)\end{array}$ & $\begin{array}{l}.158^{\star \star \star} \\
(.030)\end{array}$ & $\begin{array}{l}.307^{\star \star \star} \\
(.039)\end{array}$ & $\begin{array}{l}.365^{\star \star \star} \\
(.055)\end{array}$ & $\begin{array}{l}.371^{\star \star \star} \\
(.058)\end{array}$ & $\begin{array}{l}.293^{\star \star \star} \\
(.041)\end{array}$ \\
\hline 2007 & $\begin{array}{l}.072^{\text {*k*}} \\
(.025)\end{array}$ & $\begin{array}{l}.057^{*} \\
(.031)\end{array}$ & $\begin{array}{l}.076^{\star \star} \\
(.031)\end{array}$ & $\begin{array}{l}.062^{* *} \\
(.026)\end{array}$ & $\begin{array}{l}.194^{\star \star \star} \\
(.029)\end{array}$ & $\begin{array}{l}.251^{\star \star \star} \\
(.041)\end{array}$ & $\begin{array}{l}.256^{\star \star \star} \\
(.045)\end{array}$ & $\begin{array}{l}.181^{\star \star \star} \\
(.032)\end{array}$ \\
\hline 2008 & $\begin{array}{l}.084^{\text {* }} \\
(.033)\end{array}$ & $\begin{array}{l}.115^{\star \star \star} \\
(.043)\end{array}$ & $\begin{array}{l}.139^{\text {} \star *} \\
(.049)\end{array}$ & $\begin{array}{l}.072^{*} \\
(.036)\end{array}$ & $\begin{array}{l}.132^{\star *} \\
(.055)\end{array}$ & $\begin{array}{l}.256^{\star \star \star} \\
(.076)\end{array}$ & $\begin{array}{l}.267^{\star \star \star} \\
(.084)\end{array}$ & $\begin{array}{l}.102 \\
(.064)\end{array}$ \\
\hline 2009 & $\begin{array}{l}.162^{* \star *} \\
(.045)\end{array}$ & $\begin{array}{l}.210^{\star \star \star} \\
(.053)\end{array}$ & $\begin{array}{l}.235^{\text {} \star \star} \\
(.060)\end{array}$ & $\begin{array}{l}.146^{\star \star \star} \\
(.047)\end{array}$ & $\begin{array}{l}.193^{\star \star \star} \\
(.068)\end{array}$ & $\begin{array}{l}.341^{\text {*k }} \\
(.092)\end{array}$ & $\begin{array}{l}.355^{\star \star \star} \\
(.102)\end{array}$ & $\begin{array}{l}.157^{\star} \\
(.079)\end{array}$ \\
\hline Constant & $\begin{array}{l}.466^{\star \star \star} \\
(.096)\end{array}$ & $\begin{array}{l}.399^{\star \star \star} \\
(.095)\end{array}$ & $\begin{array}{l}.445^{\star \star \hbar} \\
(.098)\end{array}$ & $\begin{array}{l}.445^{\star \star \star} \\
(.097)\end{array}$ & $\begin{array}{l}.798^{\star \star \star} \\
(.124)\end{array}$ & $\begin{array}{l}.862^{\star \star \star} \\
(.127)\end{array}$ & $\begin{array}{l}.871^{\star \star \star} \\
(.128)\end{array}$ & $\begin{array}{l}.756^{\star \star \star} \\
(.136)\end{array}$ \\
\hline No. of districts & 68 & 68 & 68 & 68 & 68 & 68 & 68 & 68 \\
\hline Observations & 408 & 408 & 408 & 408 & 408 & 408 & 408 & 408 \\
\hline No. of instruments & 20 & 22 & 21 & 21 & 20 & 22 & 21 & 21 \\
\hline Hansen test & .01 & .01 & .00 & .02 & .00 & .01 & .00 & .00 \\
\hline Diff.-in-Hansen test & .99 & .60 & .55 & .97 & .13 & .47 & .56 & .08 \\
\hline Arellano-Bond $\operatorname{ar}(1)$ & .00 & .00 & .00 & .00 & .06 & .98 & .88 & .05 \\
\hline Arellano-Bond $\operatorname{ar}(2)$ & .00 & .00 & .00 & .00 & .00 & .00 & .00 & .00 \\
\hline
\end{tabular}


Table E 3: System GMM health total expenditure-maternal mortality

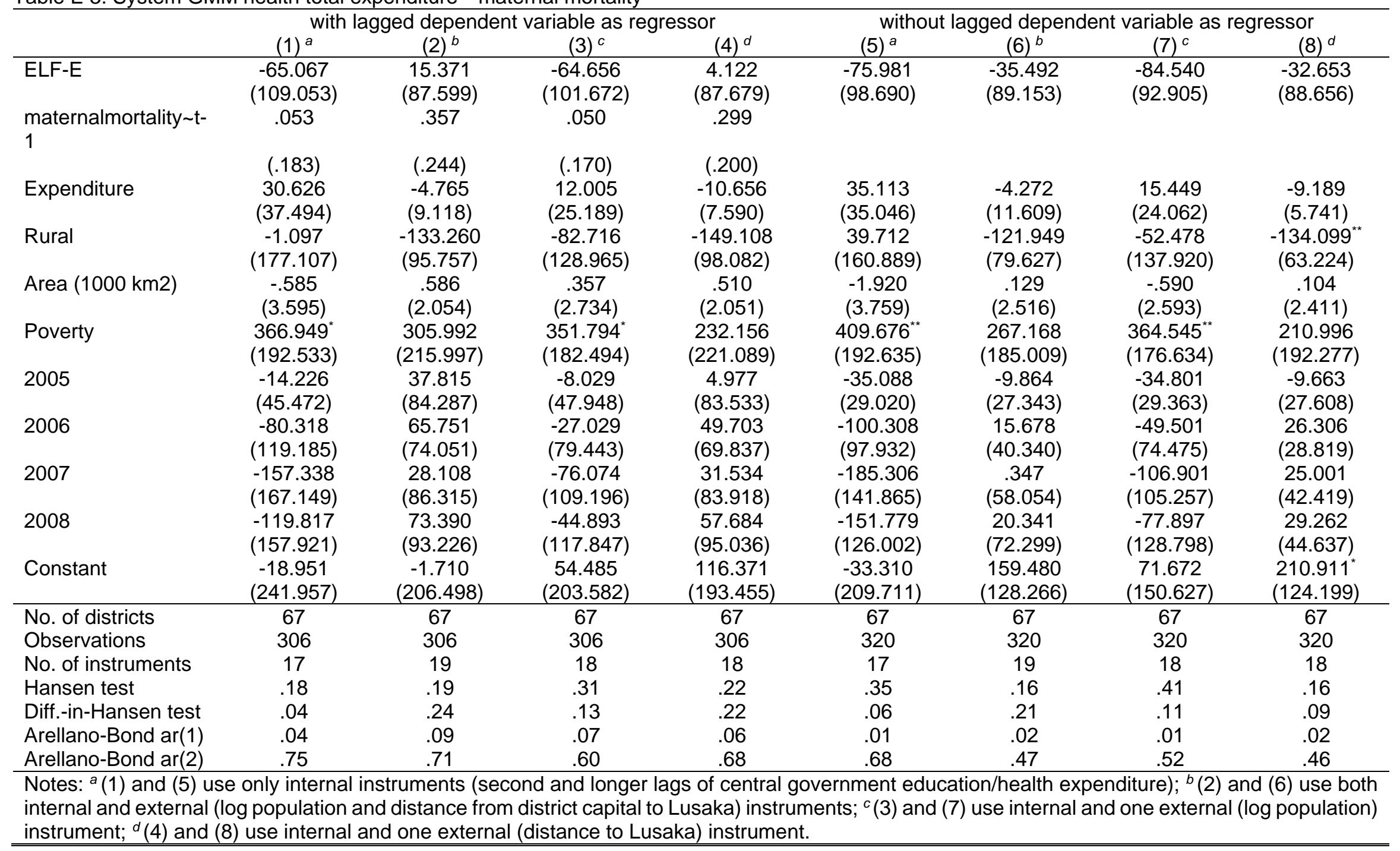


Table E 4: System GMM health total expenditure-under 5 mortality

\begin{tabular}{|c|c|c|c|c|c|c|c|c|}
\hline \multirow{2}{*}{ 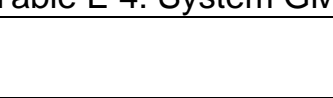 } & \multicolumn{4}{|c|}{ with lagged dependent variable as regressor } & \multicolumn{4}{|c|}{ without lagged dependent variable as regressor } \\
\hline & $(1)^{a}$ & $(2)^{b}$ & $(3)^{c}$ & $(4)^{d}$ & $(5)^{a}$ & $(6)^{b}$ & $(7)^{c}$ & $(8)^{d}$ \\
\hline ELF-E & $\begin{array}{c}-8.103 \\
(11.576)\end{array}$ & $\begin{array}{l}-8.543 \\
(9.061)\end{array}$ & $\begin{array}{c}-9.822 \\
(10.865)\end{array}$ & $\begin{array}{c}-10.369 \\
(9.639)\end{array}$ & $\begin{array}{l}-16.443 \\
(15.945)\end{array}$ & $\begin{array}{l}-13.282 \\
(16.007)\end{array}$ & $\begin{array}{l}-12.398 \\
(15.737)\end{array}$ & $\begin{array}{c}-20.333 \\
(18.718)\end{array}$ \\
\hline under5mortality $\sim \mathrm{t}-1$ & $\begin{array}{c}.378 \\
(.326)\end{array}$ & $\begin{array}{l}.590^{* *} \\
(.243)\end{array}$ & $\begin{array}{c}.427 \\
(.299)\end{array}$ & $\begin{array}{c}.496 \\
(.344)\end{array}$ & & & & \\
\hline Expenditure & $\begin{array}{c}-.090 \\
(3.411)\end{array}$ & $\begin{array}{l}-1.857 \\
(1.665)\end{array}$ & $\begin{array}{l}-1.508 \\
(2.567)\end{array}$ & $\begin{array}{c}-.683 \\
(3.081)\end{array}$ & $\begin{array}{c}.968 \\
(1.357)\end{array}$ & $\begin{array}{c}.975 \\
(1.559)\end{array}$ & $\begin{array}{c}.145 \\
(2.070)\end{array}$ & $\begin{array}{c}1.358 \\
(1.704)\end{array}$ \\
\hline Rural & $\begin{array}{c}-6.823 \\
(18.655)\end{array}$ & $\begin{array}{c}-16.049^{*} \\
(8.727)\end{array}$ & $\begin{array}{l}-13.945 \\
(14.314)\end{array}$ & $\begin{array}{c}-10.726 \\
(16.168)\end{array}$ & $\begin{array}{c}-7.432 \\
(10.814)\end{array}$ & $\begin{array}{c}-7.190 \\
(10.465)\end{array}$ & $\begin{array}{c}-8.904 \\
(11.731)\end{array}$ & $\begin{array}{c}-6.764 \\
(14.573)\end{array}$ \\
\hline Area $(1000 \mathrm{~km} 2)$ & $\begin{array}{l}-.178 \\
(.252)\end{array}$ & $\begin{array}{l}-.054 \\
(.243)\end{array}$ & $\begin{array}{l}-.113 \\
(.229)\end{array}$ & $\begin{array}{l}-.125 \\
(.282)\end{array}$ & $\begin{array}{l}-.400 \\
(.310)\end{array}$ & $\begin{array}{l}-.396 \\
(.297)\end{array}$ & $\begin{array}{c}-.348 \\
(.295)\end{array}$ & $\begin{array}{l}-.402 \\
(.348)\end{array}$ \\
\hline Poverty & $\begin{array}{c}11.737 \\
(32.590)\end{array}$ & $\begin{array}{c}-1.196 \\
(17.177)\end{array}$ & $\begin{array}{c}5.403 \\
(22.679)\end{array}$ & $\begin{array}{c}4.602 \\
(29.429)\end{array}$ & $\begin{array}{c}35.363 \\
(24.198)\end{array}$ & $\begin{array}{c}38.604 \\
(23.806)\end{array}$ & $\begin{array}{c}30.929 \\
(23.368)\end{array}$ & $\begin{array}{c}40.373 \\
(25.029)\end{array}$ \\
\hline 2005 & $\begin{array}{c}14.138 \\
(12.451)\end{array}$ & $\begin{array}{c}21.096^{*} \\
(10.734)\end{array}$ & $\begin{array}{c}15.698 \\
(11.793)\end{array}$ & $\begin{array}{c}17.748 \\
(13.914)\end{array}$ & $\begin{array}{c}.385 \\
(3.400)\end{array}$ & $\begin{array}{c}-.023 \\
(3.463)\end{array}$ & $\begin{array}{c}.719 \\
(3.365)\end{array}$ & $\begin{array}{c}.069 \\
(3.701)\end{array}$ \\
\hline 2006 & $\begin{array}{c}6.313 \\
(10.083)\end{array}$ & $\begin{array}{c}13.598 \\
(10.731)\end{array}$ & $\begin{array}{c}9.652 \\
(10.144)\end{array}$ & $\begin{array}{c}8.538 \\
(12.627)\end{array}$ & $\begin{array}{c}-10.131^{*} \\
(5.231)\end{array}$ & $\begin{array}{l}-8.355 \\
(6.232)\end{array}$ & $\begin{array}{l}-6.104 \\
(7.247)\end{array}$ & $\begin{array}{c}-11.480^{* *} \\
(4.985)\end{array}$ \\
\hline 2007 & $\begin{array}{c}4.538 \\
(26.996)\end{array}$ & $\begin{array}{c}19.558 \\
(18.020)\end{array}$ & $\begin{array}{c}12.013 \\
(22.617)\end{array}$ & $\begin{array}{c}10.635 \\
(27.633)\end{array}$ & $\begin{array}{c}-15.877^{\star \star} \\
(7.138)\end{array}$ & $\begin{array}{c}-16.859^{* *} \\
(7.801)\end{array}$ & $\begin{array}{c}-11.589 \\
(9.432)\end{array}$ & $\begin{array}{c}-20.219^{x+x+x} \\
(7.256)\end{array}$ \\
\hline 2008 & $\begin{array}{c}-6.136 \\
(33.423)\end{array}$ & $\begin{array}{c}13.346 \\
(21.167)\end{array}$ & $\begin{array}{c}4.215 \\
(27.818)\end{array}$ & $\begin{array}{c}1.604 \\
(33.471)\end{array}$ & $\begin{array}{c}-30.280^{* * \star} \\
(8.645)\end{array}$ & $\begin{array}{c}-31.129^{* k *} \\
(9.489)\end{array}$ & $\begin{array}{c}-24.961^{* *} \\
(11.986)\end{array}$ & $\begin{array}{c}-34.790 \times \\
(9.540)\end{array}$ \\
\hline Constant & $\begin{array}{l}28.874^{*} \\
(14.244)\end{array}$ & $\begin{array}{c}24.690 \\
(18.423)\end{array}$ & $\begin{array}{l}34.930 \\
(14.438)\end{array}$ & $\begin{array}{c}26.581^{*} \\
(13.932)\end{array}$ & $\begin{array}{l}54.496^{\star *} \\
(22.338)\end{array}$ & $\begin{array}{l}51.453^{\star \star} \\
(21.955)\end{array}$ & $\begin{array}{l}56.790^{*} \\
(23.195)\end{array}$ & $\begin{array}{l}52.892^{* *} \\
(26.005)\end{array}$ \\
\hline No. of districts & 67 & 67 & 67 & 67 & 67 & 67 & 67 & 67 \\
\hline Observations & 324 & 324 & 324 & 324 & 329 & 329 & 329 & 329 \\
\hline No. of instruments & 17 & 19 & 18 & 18 & 17 & 19 & 18 & 18 \\
\hline Hansen test & 13 & .17 & .07 & .21 & 12 & .06 & .08 & .12 \\
\hline Diff.-in-Hansen test & .02 & .03 & .01 & .05 & .49 & .73 & .19 & .71 \\
\hline Arellano-Bond ar(1) & 15 & .12 & .14 & 15 & 17 & .18 & .18 & .17 \\
\hline Arellano-Bond ar(2) & .57 & .37 & .50 & .47 & .29 & .29 & .28 & .29 \\
\hline
\end{tabular}


Table E 5: System GMM health total expenditure-total beds per 1000

\begin{tabular}{|c|c|c|c|c|c|c|c|c|}
\hline & \multicolumn{4}{|c|}{ with lagged dependent variable as regressor } & \multicolumn{4}{|c|}{ without lagged dependent variable as regressor } \\
\hline & $(1)^{a}$ & $(2)^{b}$ & $(3)^{c}$ & $(4)^{d}$ & $(5)^{a}$ & $(6)^{b}$ & $(7)^{c}$ & $(8)^{d}$ \\
\hline ELF-E & $\begin{array}{c}-1.156^{\star *} \\
(.539)\end{array}$ & $\begin{array}{c}-.338 \\
(.256)\end{array}$ & $\begin{array}{l}-.496 \\
(.334)\end{array}$ & $\begin{array}{l}-.772^{*} \\
(.423)\end{array}$ & $\begin{array}{c}-1.409^{* *} \\
(.561)\end{array}$ & $\begin{array}{c}-1.657^{* *} \\
(.635)\end{array}$ & $\begin{array}{c}-1.698^{\star \star *} \\
(.634)\end{array}$ & $\begin{array}{c}-1.666^{\star \star \star} \\
(.615)\end{array}$ \\
\hline tbedspc $\sim \mathrm{t}-1$ & $\begin{array}{l}.218 \\
(.196)\end{array}$ & $\begin{array}{l}.808^{\star \star \star} \\
(.111)\end{array}$ & $\begin{array}{l}.726^{\star \star \star} \\
(.147)\end{array}$ & $\begin{array}{l}.504^{\star \star} \\
(.208)\end{array}$ & & & & \\
\hline Expenditure & $\begin{array}{l}.044 \\
(.031)\end{array}$ & $\begin{array}{c}-.002 \\
(.024)\end{array}$ & $\begin{array}{l}-.018 \\
(.038)\end{array}$ & $\begin{array}{l}.043 \\
(.033)\end{array}$ & $\begin{array}{l}.055 \\
(.036)\end{array}$ & $\begin{array}{l}-.111 \\
(.104)\end{array}$ & $\begin{array}{l}-.172 \\
(.123)\end{array}$ & $\begin{array}{c}.069 \\
(.053)\end{array}$ \\
\hline Rural & $\begin{array}{l}-.417 \\
(.359)\end{array}$ & $\begin{array}{r}-.261 \\
(.266)\end{array}$ & $\begin{array}{l}-.442 \\
(.366)\end{array}$ & $\begin{array}{c}-.203 \\
(.227)\end{array}$ & $\begin{array}{l}-.509 \\
(.392)\end{array}$ & $\begin{array}{c}-1.175^{\star *} \\
(.583)\end{array}$ & $\begin{array}{c}-1.356^{\star *} \\
(.655)\end{array}$ & $\begin{array}{l}-.476 \\
(.426)\end{array}$ \\
\hline Area $(1000 \mathrm{~km} 2)$ & $\begin{array}{l}.010 \\
(.012)\end{array}$ & $\begin{array}{l}.003 \\
(.006)\end{array}$ & $\begin{array}{l}.004 \\
(.007)\end{array}$ & $\begin{array}{l}.003 \\
(.009)\end{array}$ & $\begin{array}{l}.011 \\
(.016)\end{array}$ & $\begin{array}{l}.020 \\
(.019)\end{array}$ & $\begin{array}{c}.026 \\
(.020)\end{array}$ & $\begin{array}{c}.011 \\
(.017)\end{array}$ \\
\hline Poverty & $\begin{array}{l}-.479 \\
(.607)\end{array}$ & $\begin{array}{l}.011 \\
(.317)\end{array}$ & $\begin{array}{l}.093 \\
(.350)\end{array}$ & $\begin{array}{l}-.306 \\
(.453)\end{array}$ & $\begin{array}{l}-.614 \\
(.735)\end{array}$ & $\begin{array}{c}-.070 \\
(1.022)\end{array}$ & $\begin{array}{l}.041 \\
(.992)\end{array}$ & $\begin{array}{l}-.718 \\
(.850)\end{array}$ \\
\hline 2005 & $\begin{array}{l}-.070 \\
(.117)\end{array}$ & $\begin{array}{c}.062 \\
(.113)\end{array}$ & $\begin{array}{l}.072 \\
(.103)\end{array}$ & $\begin{array}{c}-.011 \\
(.111)\end{array}$ & $\begin{array}{l}-.101 \\
(.105)\end{array}$ & $\begin{array}{l}-.064 \\
(.113)\end{array}$ & $\begin{array}{l}-.057 \\
(.113)\end{array}$ & $\begin{array}{l}-.108 \\
(.112)\end{array}$ \\
\hline 2006 & $\begin{array}{l}-.221 \\
(.179)\end{array}$ & $\begin{array}{c}-.020 \\
(.117)\end{array}$ & $\begin{array}{c}.012 \\
(.137)\end{array}$ & $\begin{array}{c}-.153 \\
(.142)\end{array}$ & $\begin{array}{l}-.313^{* *} \\
(.149)\end{array}$ & $\begin{array}{l}.147 \\
(.300)\end{array}$ & $\begin{array}{l}.310 \\
(.333)\end{array}$ & $\begin{array}{l}-.373^{*} \\
(.205)\end{array}$ \\
\hline 2007 & $\begin{array}{l}-.251 \\
(.173)\end{array}$ & $\begin{array}{c}.091 \\
(.129)\end{array}$ & $\begin{array}{l}.156 \\
(.159)\end{array}$ & $\begin{array}{c}-.205 \\
(.210)\end{array}$ & $\begin{array}{l}-.346^{*} \\
(.175)\end{array}$ & $\begin{array}{l}.329 \\
(.402)\end{array}$ & $\begin{array}{c}.538 \\
(.443)\end{array}$ & $\begin{array}{l}-.435^{*} \\
(.239)\end{array}$ \\
\hline 2008 & $\begin{array}{l}-.474^{* *} \\
(.209)\end{array}$ & $\begin{array}{l}-.017 \\
(.154)\end{array}$ & $\begin{array}{l}.065 \\
(.208)\end{array}$ & $\begin{array}{l}-.377 \\
(.245)\end{array}$ & $\begin{array}{l}-.561^{\star *} \\
(.213)\end{array}$ & $\begin{array}{c}.522 \\
(.567)\end{array}$ & $\begin{array}{c}.801 \\
(.631)\end{array}$ & $\begin{array}{l}-.631^{\star *} \\
(.303)\end{array}$ \\
\hline Constant & $\begin{array}{c}2.666^{\star \star \star \star} \\
(.883)\end{array}$ & $\begin{array}{l}.628 \\
(.470)\end{array}$ & $\begin{array}{c}.953 \\
(.632)\end{array}$ & $\begin{array}{l}1.633^{* *} \\
(.778)\end{array}$ & $\begin{array}{c}3.372^{\star \star \star} \\
(.528)\end{array}$ & $\begin{array}{c}3.576^{\star \star *} \\
(.757)\end{array}$ & $\begin{array}{c}3.613^{* * *} \\
(.827)\end{array}$ & $\begin{array}{c}3.507^{\star \star \star} \\
(.640)\end{array}$ \\
\hline No. of districts & 67 & 67 & 67 & 67 & 67 & 67 & 67 & 67 \\
\hline Observations & 324 & 324 & 324 & 324 & 329 & 329 & 329 & 329 \\
\hline No. of instruments & 17 & 19 & 18 & 18 & 17 & 19 & 18 & 18 \\
\hline Hansen test & .27 & .16 & .14 & .13 & .38 & .05 & .07 & .29 \\
\hline Diff.-in-Hansen test & .67 & .91 & .59 & .72 & 1.00 & .21 & .03 & .77 \\
\hline Arellano-Bond $\operatorname{ar}(1)$ & .08 & .02 & .02 & .02 & .03 & .59 & .88 & .03 \\
\hline Arellano-Bond $\operatorname{ar}(2)$ & .34 & .12 & .12 & .22 & .52 & .25 & .32 & .48 \\
\hline
\end{tabular}


Table E 6: System GMM health total expenditure-BCG immunization rate

\begin{tabular}{|c|c|c|c|c|c|c|c|c|}
\hline & \multicolumn{4}{|c|}{ with lagged dependent variable as regressor } & \multicolumn{4}{|c|}{ without lagged dependent variable as regressor } \\
\hline & $(1)^{a}$ & $(2)^{b}$ & $(3)^{c}$ & $(4)^{d}$ & $(5)^{a}$ & $(6)^{b}$ & $(7)^{c}$ & $(8)^{d}$ \\
\hline ELF-E & .116 & .131 & .120 & $.140^{*}$ & $.157^{\star}$ & .160 & $.152^{*}$ & $.180^{*}$ \\
\hline BCGimmun t-1 & $\begin{array}{c}(.082) \\
.073 \\
(.055)\end{array}$ & $\begin{array}{c}(.085) \\
.074 \\
(.064)\end{array}$ & $\begin{array}{c}(.083) \\
.054 \\
(.053)\end{array}$ & $\begin{array}{c}(.082) \\
.090 \\
(.062)\end{array}$ & $(.089)$ & $(.097)$ & $(.085)$ & $(.098)$ \\
\hline Expenditure & -.005 & $.018^{*}$ & .011 & .003 & -.011 & .013 & .007 & -.003 \\
\hline & $(.011)$ & $(.010)$ & $(.010)$ & $(.011)$ & $(.011)$ & $(.012)$ & $(.012)$ & $(.014)$ \\
\hline Rural & $\begin{array}{c}-.007 \\
(.101)\end{array}$ & $\begin{array}{c}.129 \\
(.081)\end{array}$ & $\begin{array}{c}.091 \\
(.077)\end{array}$ & $\begin{array}{c}.048 \\
(.080)\end{array}$ & $\begin{array}{c}-.063 \\
(.108)\end{array}$ & $\begin{array}{c}.094 \\
(.094)\end{array}$ & $\begin{array}{c}.060 \\
(.089)\end{array}$ & $\begin{array}{c}.002 \\
(.107)\end{array}$ \\
\hline Area $(1000 \mathrm{~km} 2)$ & $\begin{array}{c}.003 \\
(.003)\end{array}$ & $\begin{array}{c}.002 \\
(.003)\end{array}$ & $\begin{array}{c}.002 \\
(.003)\end{array}$ & $\begin{array}{c}.002 \\
(.003)\end{array}$ & $\begin{array}{c}.003 \\
(.003)\end{array}$ & $\begin{array}{c}.001 \\
(.004)\end{array}$ & $\begin{array}{c}.002 \\
(.004)\end{array}$ & $\begin{array}{c}.002 \\
(.004)\end{array}$ \\
\hline Poverty & $\begin{array}{l}.354^{* \star *} \\
(.115)\end{array}$ & $\begin{array}{l}.285^{\star \star} \\
(.126)\end{array}$ & $\begin{array}{l}.355^{\text {thx }} \\
(.127)\end{array}$ & $\begin{array}{l}.314^{* \star \star} \\
(.116)\end{array}$ & $\begin{array}{l}.434^{* \star \star} \\
(.121)\end{array}$ & $\begin{array}{l}.334^{*} \\
(.137)\end{array}$ & $\begin{array}{l}.404^{\star \star \star} \\
(.128)\end{array}$ & $\begin{array}{l}.394^{4 k} \\
(.134)\end{array}$ \\
\hline 2005 & $\begin{array}{c}-.035 \\
(.036)\end{array}$ & $\begin{array}{l}-.040 \\
(.043)\end{array}$ & $\begin{array}{c}-.035 \\
(.037)\end{array}$ & $\begin{array}{c}-.042 \\
(.039)\end{array}$ & $\begin{array}{l}-.020 \\
(.028)\end{array}$ & $\begin{array}{l}-.010 \\
(.030)\end{array}$ & $\begin{array}{l}-.019 \\
(.028)\end{array}$ & $\begin{array}{l}-.015 \\
(.029)\end{array}$ \\
\hline 2006 & $\begin{array}{c}.025 \\
(.046)\end{array}$ & $\begin{array}{c}-.032 \\
(.056)\end{array}$ & $\begin{array}{c}-.011 \\
(.052)\end{array}$ & $\begin{array}{l}-.005 \\
(.053)\end{array}$ & $\begin{array}{c}.036 \\
(.035)\end{array}$ & $\begin{array}{c}-.014 \\
(.052)\end{array}$ & $\begin{array}{c}-.003 \\
(.051)\end{array}$ & $\begin{array}{c}.013 \\
(.049)\end{array}$ \\
\hline 2007 & $\begin{array}{l}-.037 \\
(.054)\end{array}$ & $\begin{array}{l}-.131^{\text {*k }} \\
(.053)\end{array}$ & $\begin{array}{l}-.094^{*} \\
(.051)\end{array}$ & $\begin{array}{l}-.077 \\
(.055)\end{array}$ & $\begin{array}{l}-.003 \\
(.040)\end{array}$ & $\begin{array}{l}-.087 \\
(.054)\end{array}$ & $\begin{array}{l}-.065 \\
(.053)\end{array}$ & $\begin{array}{l}-.030 \\
(.058)\end{array}$ \\
\hline 2008 & $\begin{array}{c}.030 \\
(.083)\end{array}$ & $\begin{array}{l}-.115 \\
(.079)\end{array}$ & $\begin{array}{c}-.063 \\
(.079)\end{array}$ & $\begin{array}{c}-.032 \\
(.084)\end{array}$ & $\begin{array}{c}.078 \\
(.066)\end{array}$ & $\begin{array}{l}-.064 \\
(.087)\end{array}$ & $\begin{array}{l}-.026 \\
(.088)\end{array}$ & $\begin{array}{c}.026 \\
(.099)\end{array}$ \\
\hline Constant & $\begin{array}{l}.846^{\star \star \star} \\
(.131)\end{array}$ & $\begin{array}{l}.784^{* \star *} \\
(.132)\end{array}$ & $\begin{array}{l}.788^{*+x} \\
(.117)\end{array}$ & $\begin{array}{l}.808^{* \star \star} \\
(.119)\end{array}$ & $\begin{array}{l}.912^{* \star \star} \\
(.127)\end{array}$ & $\begin{array}{l}.851^{\star \star x} \\
(.130)\end{array}$ & $\begin{array}{l}.831^{\star \star} \\
(.120)\end{array}$ & $\begin{array}{l}.882^{2+3} \\
(.131)\end{array}$ \\
\hline No. of districts & 67 & 67 & 67 & 67 & 67 & 67 & 67 & 67 \\
\hline Observations & 324 & 324 & 324 & 324 & 329 & 329 & 329 & 329 \\
\hline No. of instruments & 17 & 19 & 18 & 18 & 17 & 19 & 18 & 18 \\
\hline Hansen test & 47 & .08 & .25 & .32 & .72 & 17 & .49 & .38 \\
\hline Diff.-in-Hansen test & .31 & .10 & .63 & .83 & .23 & .11 & .70 & .28 \\
\hline Arellano-Bond $\operatorname{ar}(1)$ & .01 & .01 & .01 & .01 & .00 & .00 & .00 & .00 \\
\hline Arellano-Bond ar(2) & .48 & .77 & .88 & .51 & .81 & .98 & .99 & .91 \\
\hline
\end{tabular}


Table E 7: System GMM health total expenditure-DPT3 immunization rate

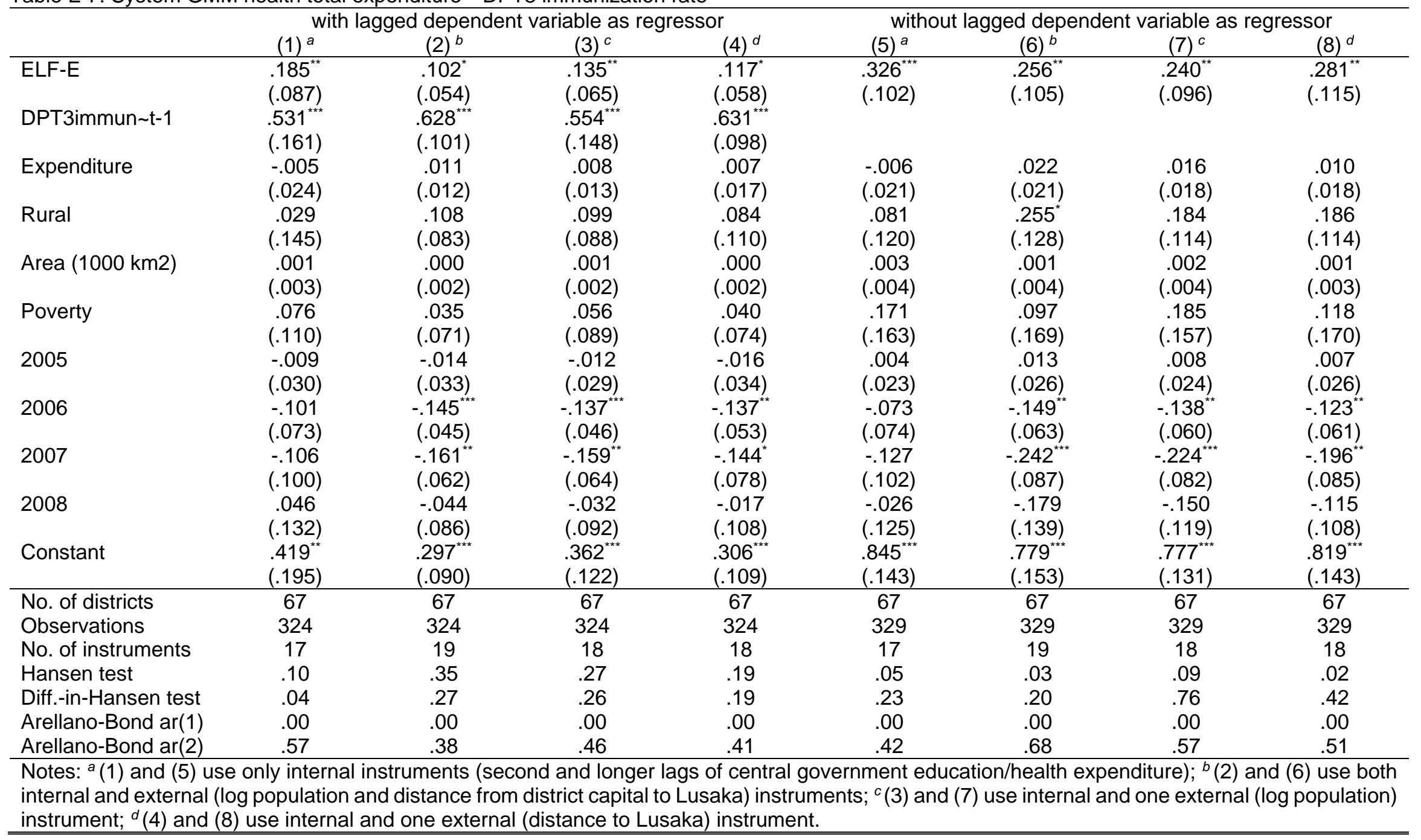


Table E 8: System GMM health total expenditure-OPV3 immunization rate

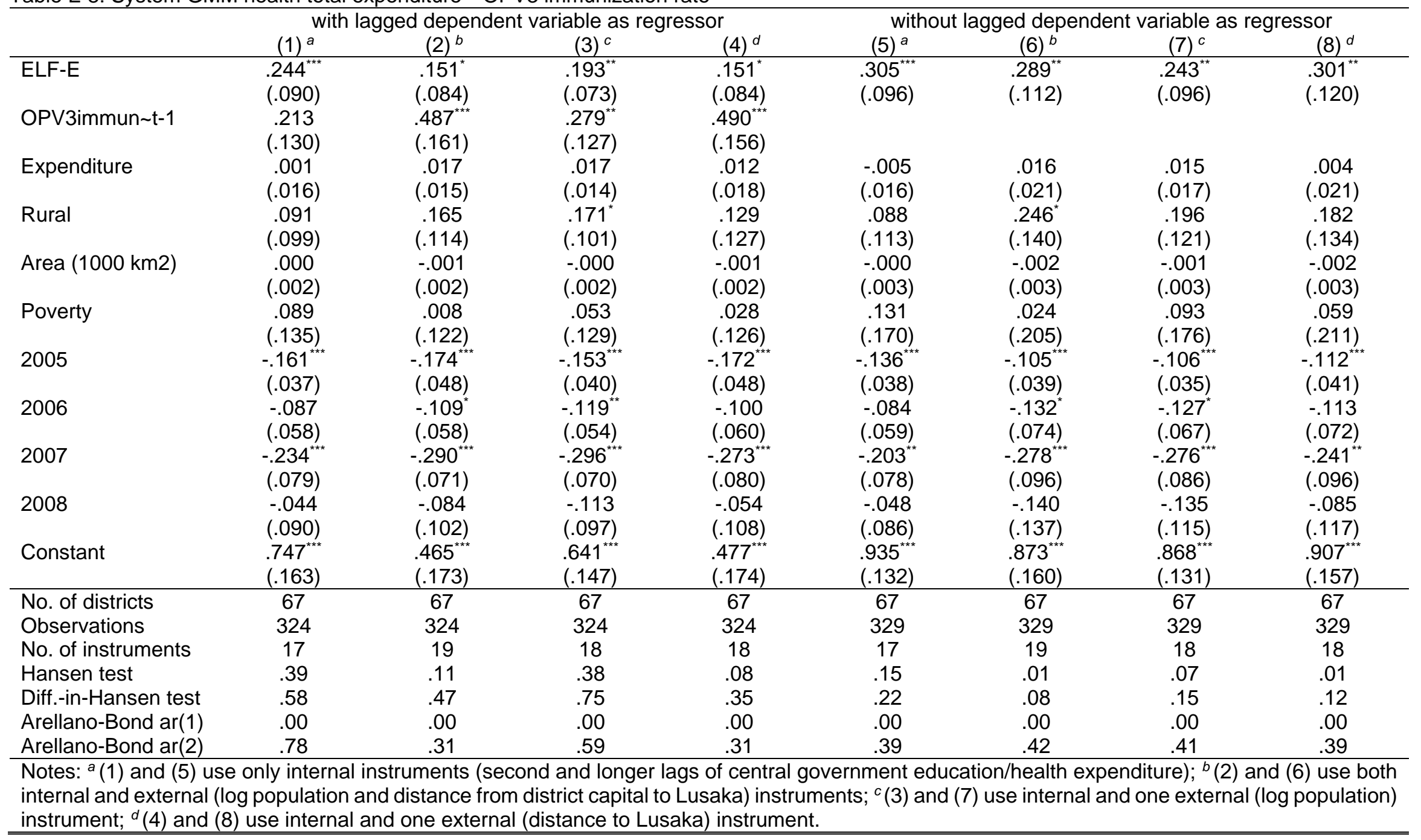


Table E 9: System GMM health total expenditure-measles immunization rate

\begin{tabular}{|c|c|c|c|c|c|c|c|c|}
\hline & \multicolumn{4}{|c|}{ with lagged dependent variable as regressor } & \multicolumn{4}{|c|}{ without lagged dependent variable as regressor } \\
\hline & $(1)^{a}$ & $(2)^{b}$ & $(3)^{c}$ & $(4)^{d}$ & $(5)^{a}$ & $(6)^{b}$ & $(7)^{c}$ & $(8)^{d}$ \\
\hline \multirow[t]{2}{*}{ ELF-E } & $.213^{\star *}$ & $.189^{* \star}$ & $.188^{* *}$ & $.197^{\star \star}$ & $.240^{\star *}$ & $.226^{* \star}$ & $.220^{\star \star}$ & $.236^{*}$ \\
\hline & $(.094)$ & $(.084)$ & $(.080)$ & $(.091)$ & $(.101)$ & $(.112)$ & $(.093)$ & $(.121)$ \\
\hline \multirow[t]{2}{*}{ Measles $\sim \mathrm{t}-1$} & .087 & $.232^{* \star}$ & $.193^{*}$ & $.167^{\star \star}$ & & & & \\
\hline & $(.074)$ & $(.093)$ & $(.100)$ & $(.083)$ & & & & \\
\hline \multirow[t]{2}{*}{ Expenditure } & .006 & $.023^{*}$ & .021 & .011 & .006 & $.031^{\star *}$ & $.026^{*}$ & .015 \\
\hline & $(.008)$ & $(.014)$ & $(.013)$ & $(.012)$ & $(.009)$ & $(.015)$ & $(.015)$ & $(.013)$ \\
\hline \multirow[t]{2}{*}{ Rural } & $.112^{*}$ & $.179^{* *}$ & $.180^{\star \star}$ & $.129^{*}$ & $.119^{*}$ & $.260^{\star \star \star}$ & $.234^{\star * *}$ & $.169^{*}$ \\
\hline & $(.064)$ & $(.084)$ & $(.082)$ & $(.073)$ & $(.069)$ & $(.094)$ & $(.088)$ & $(.090)$ \\
\hline \multirow[t]{2}{*}{ Area $(1000 \mathrm{~km} 2)$} & -.000 & -.001 & -.000 & -.000 & -.001 & -.001 & .000 & -.002 \\
\hline & $(.004)$ & $(.003)$ & $(.003)$ & $(.003)$ & $(.005)$ & $(.004)$ & $(.004)$ & $(.005)$ \\
\hline \multirow[t]{2}{*}{ Poverty } & .205 & .050 & .071 & .153 & .227 & .014 & .057 & .178 \\
\hline & $(.162)$ & $(.135)$ & $(.137)$ & $(.155)$ & $(.197)$ & $(.192)$ & $(.175)$ & $(.225)$ \\
\hline \multirow[t]{2}{*}{2005} & .014 & .006 & .009 & .011 & .017 & .009 & .013 & .011 \\
\hline & $(.021)$ & $(.024)$ & $(.023)$ & $(.023)$ & $(.021)$ & $(.023)$ & $(.022)$ & $(.022)$ \\
\hline \multirow[t]{2}{*}{2006} & .032 & -.020 & -.015 & .014 & .035 & -.028 & -.019 & .012 \\
\hline & $(.029)$ & $(.043)$ & $(.043)$ & $(.037)$ & $(.029)$ & $(.046)$ & $(.044)$ & $(.039)$ \\
\hline \multirow[t]{2}{*}{2007} & -.002 & -.087 & -.085 & -.026 & -.001 & -.111 & -.100 & -.037 \\
\hline & $(.058)$ & $(.070)$ & $(.071)$ & $(.069)$ & $(.056)$ & $(.072)$ & $(.071)$ & $(.070)$ \\
\hline \multirow[t]{2}{*}{2008} & -.001 & -.087 & -.082 & -.031 & .008 & -.127 & -.108 & -.045 \\
\hline & $(.061)$ & $(.084)$ & $(.085)$ & $(.071)$ & $(.066)$ & $(.093)$ & $(.091)$ & $(.083)$ \\
\hline \multirow[t]{2}{*}{ Constant } & $.590^{\star \star \star}$ & $.516^{\star \star \star}$ & $.534^{\star \star \star}$ & $.543^{\star \star \star}$ & $.650^{\star \star \star}$ & $.685^{\star \star \star \star}$ & $.667^{\star \star \star *}$ & $.654^{\star \star \star}$ \\
\hline & $(.100)$ & $(.107)$ & $(.106)$ & $(.101)$ & $(.110)$ & $(.121)$ & $(.104)$ & $(.128)$ \\
\hline No. of districts & 67 & 67 & 67 & 67 & 67 & 67 & 67 & 67 \\
\hline Observations & 324 & 324 & 324 & 324 & 329 & 329 & 329 & 329 \\
\hline No. of instruments & 17 & 19 & 18 & 18 & 17 & 19 & 18 & 18 \\
\hline Hansen test & .08 & .09 & .08 & .10 & .10 & .01 & .03 & .03 \\
\hline Diff.-in-Hansen test & .36 & .38 & .51 & .55 & .09 & .01 & .08 & .04 \\
\hline Arellano-Bond $\operatorname{ar}(1)$ & .00 & .00 & .00 & .00 & .00 & .00 & .00 & .00 \\
\hline Arellano-Bond $\operatorname{ar}(2)$ & .21 & .31 & .32 & .22 & .41 & .60 & .60 & .49 \\
\hline
\end{tabular}


Table E 10: System GMM health total expenditure-FIC immunization rate

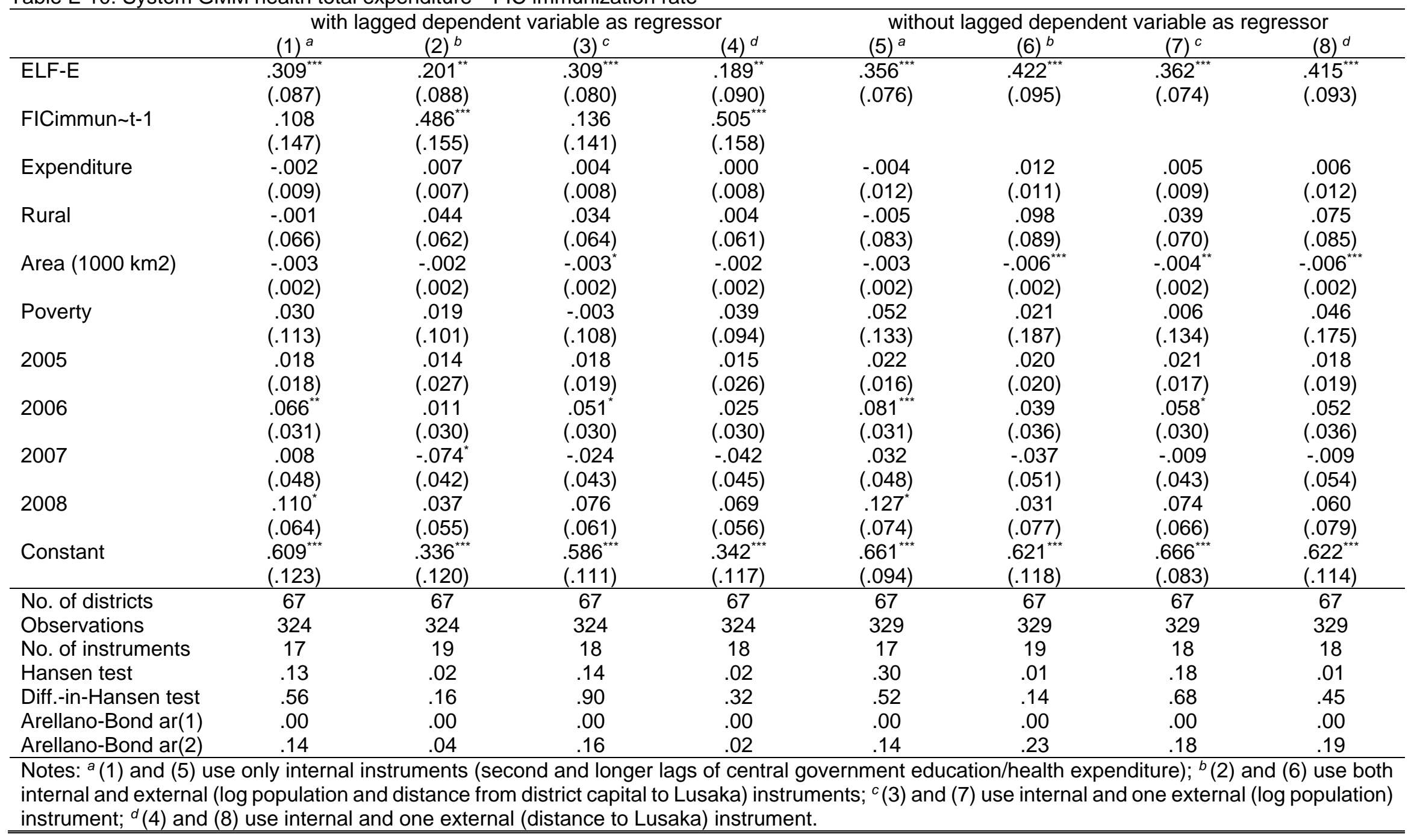


Table E 11: System GMM health total expenditure-underweight5

\begin{tabular}{|c|c|c|c|c|c|c|c|c|}
\hline & \multicolumn{4}{|c|}{ with lagged dependent variable as regressor } & \multicolumn{4}{|c|}{ without lagged dependent variable as regressor } \\
\hline & $(1)^{a}$ & $(2)^{b}$ & $(3)^{c}$ & $(4)^{d}$ & $(5)^{a}$ & $(6)^{b}$ & $(7)^{c}$ & $(8)^{d}$ \\
\hline \multirow[t]{2}{*}{ ELF-E } & 2.989 & .547 & 2.954 & .844 & $-11.765^{\star \star \star}$ & $-12.456^{\star \star \star}$ & $-12.092^{\star \star \star}$ & $-11.593^{\star \star \star}$ \\
\hline & $(1.971)$ & $(1.344)$ & $(1.929)$ & $(1.599)$ & $(2.586)$ & $(2.946)$ & $(2.403)$ & $(3.135)$ \\
\hline \multirow[t]{2}{*}{ underweight5 $\sim \mathrm{t}-1$} & $1.076^{\star \star \star}$ & $.912^{\star \star \star}$ & $1.073^{\star \star \star}$ & $.935^{\star \star \star}$ & & & & \\
\hline & $(.126)$ & $(.086)$ & $(.125)$ & $(.107)$ & & & & \\
\hline \multirow[t]{2}{*}{ Expenditure } & .182 & $.236^{\star \star}$ & $.180^{*}$ & .230 & .449 & .208 & .328 & .136 \\
\hline & $(.118)$ & (.113) & $(.105)$ & $(.145)$ & $(.346)$ & $(.360)$ & $(.390)$ & $(.233)$ \\
\hline \multirow[t]{2}{*}{ Rural } & 1.066 & $1.693^{\star \star \star}$ & 1.092 & 1.495 & $4.832^{\star *}$ & 3.655 & $4.225^{*}$ & 3.172 \\
\hline & $(.855)$ & $(.632)$ & $(.729)$ & $(.980)$ & $(2.000)$ & $(2.581)$ & $(2.136)$ & $(2.102)$ \\
\hline \multirow[t]{2}{*}{ Area (1000 km2) } & .018 & .021 & .018 & .029 & .019 & -.007 & .029 & -.018 \\
\hline & $(.029)$ & $(.015)$ & $(.017)$ & $(.026)$ & $(.073)$ & $(.097)$ & $(.071)$ & $(.100)$ \\
\hline \multirow[t]{2}{*}{ Poverty } & $-4.636^{* * *}$ & $-3.657^{\star \star *}$ & $-4.637^{* \star *}$ & $-3.873^{* *}$ & 1.176 & .285 & .795 & 1.033 \\
\hline & $(1.532)$ & $(1.269)$ & $(1.410)$ & $(1.595)$ & $(3.790)$ & $(5.016)$ & (3.662) & $(5.113)$ \\
\hline \multirow[t]{2}{*}{2005} & $4.510^{\star \star \star}$ & $3.549^{\star \star \star}$ & $4.478^{\star \star \star}$ & $3.939^{\star \star \star}$ & $-.885^{*}$ & $-.930^{*}$ & $-.874^{*}$ & $-.946^{\star}$ \\
\hline & $(1.231)$ & $(.815)$ & $(.953)$ & $(1.351)$ & $(.487)$ & $(.545)$ & $(.488)$ & $(.539)$ \\
\hline \multirow[t]{2}{*}{2006} & $3.010^{\star \star}$ & $1.914^{\star *}$ & $2.990^{\star \star \star}$ & 2.277 & $-4.150^{\star \star \star}$ & $-3.413^{\star \star \star}$ & $-3.853^{\star \star \star}$ & $-3.167^{\star \star \star}$ \\
\hline & (1.296) & $(.812)$ & $(.936)$ & $(1.555)$ & $(1.212)$ & $(1.182)$ & $(1.313)$ & $(.844)$ \\
\hline \multirow[t]{2}{*}{2007} & 1.174 & -.486 & 1.146 & -.014 & $-8.536^{\star \star \star}$ & $-7.491^{\star * *}$ & $-8.067^{\star \star \star}$ & $-7.240^{\star \star \star}$ \\
\hline & $(1.608)$ & $(.903)$ & $(1.244)$ & $(1.817)$ & (1.684) & $(1.687)$ & $(1.857)$ & $(1.228)$ \\
\hline \multirow[t]{2}{*}{2008} & .817 & -1.562 & .793 & -.981 & $-13.166^{* \star *}$ & $-11.590^{* \star *}$ & $-12.451^{\star \star \star}$ & $-11.228^{\star \star \star}$ \\
\hline & $(2.204)$ & $(1.293)$ & $(1.830)$ & $(2.419)$ & $(2.450)$ & $(2.382)$ & $(2.692)$ & $(1.703)$ \\
\hline \multirow[t]{2}{*}{ Constant } & $-5.860^{\star \star}$ & -2.533 & $-5.794^{\star *}$ & -3.165 & $16.274^{\star \star \star}$ & $18.213^{\star \star \star}$ & $17.158^{\star \star \star}$ & $17.918^{\star \star \star}$ \\
\hline & $(2.911)$ & $(2.253)$ & $(2.900)$ & $(2.646)$ & $(2.937)$ & $(3.579)$ & $(3.084)$ & $(3.456)$ \\
\hline No. of districts & 67 & 67 & 67 & 67 & 67 & 67 & 67 & 67 \\
\hline Observations & 324 & 324 & 324 & 324 & 329 & 329 & 329 & 329 \\
\hline No. of instruments & 17 & 19 & 18 & 18 & 17 & 19 & 18 & 18 \\
\hline Hansen test & .66 & .64 & .75 & .59 & .00 & .00 & .01 & .00 \\
\hline Diff.-in-Hansen test & .61 & .83 & .60 & .80 & .05 & .00 & .08 & .00 \\
\hline Arellano-Bond $\operatorname{ar}(1)$ & .00 & .00 & .00 & .00 & .80 & .74 & .97 & .63 \\
\hline Arellano-Bond $\operatorname{ar}(2)$ & .36 & .31 & .37 & .30 & .07 & .08 & .08 & .08 \\
\hline $\begin{array}{l}\text { Notes: }{ }^{a}(1) \text { and (5) } \\
\text { internal and external } \\
\text { instrument; }{ }^{d}(4) \text { and }\end{array}$ & $y$ inte & 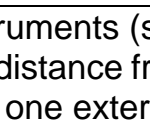 & nd lo & f cent & $\begin{array}{l}\text { ment ec } \\
; ;^{c}(3) \text { a }\end{array}$ & /health & ure $) ;{ }^{b}(2$ & $\begin{array}{l}\text { (6) use bo } \\
\text { g populatio }\end{array}$ \\
\hline
\end{tabular}


Table E 12: System GMM health total expenditure-HC_Staffpc

\begin{tabular}{|c|c|c|c|c|c|c|c|c|}
\hline & \multicolumn{4}{|c|}{ with lagged dependent variable as regressor } & \multicolumn{4}{|c|}{ without lagged dependent variable as regressor } \\
\hline & $(1)^{a}$ & $(2)^{b}$ & $(3)^{c}$ & $(4)^{d}$ & $(5)^{a}$ & $(6)^{b}$ & $(7)^{c}$ & $(8)^{d}$ \\
\hline \multirow[t]{2}{*}{ ELF-E } & .524 & -.016 & .402 & -.002 & $2.625^{\star \star}$ & $3.058^{\star \star}$ & $2.892^{\star \star}$ & $3.096^{\star \star}$ \\
\hline & $(.408)$ & $(.205)$ & $(.368)$ & $(.215)$ & $(1.298)$ & $(1.451)$ & $(1.264)$ & $(1.430)$ \\
\hline \multirow[t]{2}{*}{ HC_Staffpc $\sim \mathrm{t}-1$} & $.722^{\star \star \star}$ & $.912^{\star \star \star}$ & $.785^{\star \star *}$ & $.906^{\star \star \star}$ & & & & \\
\hline & $(.105)$ & $(.047)$ & $(.081)$ & $(.055)$ & & & & \\
\hline \multirow[t]{2}{*}{ Expenditure } & -.044 & -.038 & $-.058^{*}$ & -.035 & -.012 & -.073 & -.204 & .135 \\
\hline & $(.041)$ & $(.025)$ & $(.032)$ & $(.038)$ & $(.037)$ & $(.148)$ & $(.199)$ & $(.102)$ \\
\hline \multirow[t]{2}{*}{ Rural } & $-.542^{\star *}$ & $-.307^{*}$ & $-.518^{\star \star}$ & -.301 & $-1.266^{\star \star \star}$ & $-1.720^{\star \star}$ & $-2.354^{\star \star}$ & -.518 \\
\hline & $(.209)$ & $(.177)$ & $(.202)$ & $(.206)$ & $(.433)$ & $(.853)$ & $(.986)$ & $(.696)$ \\
\hline \multirow[t]{2}{*}{ Area (1000 km2) } & -.012 & -.003 & -.009 & -.004 & $-.051^{\star *}$ & $-.054^{*}$ & -.041 & $-.075^{* *}$ \\
\hline & $(.008)$ & $(.005)$ & $(.007)$ & $(.006)$ & $(.025)$ & $(.029)$ & $(.031)$ & $(.029)$ \\
\hline \multirow[t]{2}{*}{ Poverty } & -.576 & .059 & -.323 & .031 & $-3.203^{* *}$ & -2.290 & -2.536 & $-3.679^{*}$ \\
\hline & $(.521)$ & $(.226)$ & $(.387)$ & $(.266)$ & (1.409) & $(1.875)$ & (1.699) & $(1.721)$ \\
\hline \multirow[t]{2}{*}{2005} & .057 & .062 & .070 & .060 & -.000 & .035 & .039 & .014 \\
\hline & $(.111)$ & $(.127)$ & $(.114)$ & $(.128)$ & $(.087)$ & $(.099)$ & $(.096)$ & $(.095)$ \\
\hline \multirow[t]{2}{*}{2006} & .161 & .158 & .198 & .147 & -.046 & .096 & .469 & -.436 \\
\hline & $(.157)$ & $(.128)$ & $(.137)$ & $(.139)$ & $(.112)$ & $(.444)$ & $(.571)$ & $(.305)$ \\
\hline \multirow[t]{2}{*}{2007} & .340 & $.339^{*}$ & $.406^{\star \star}$ & .325 & .030 & .288 & .803 & -.502 \\
\hline & $(.222)$ & $(.182)$ & $(.187)$ & $(.215)$ & (.171) & $(.617)$ & $(.791)$ & $(.376)$ \\
\hline \multirow[t]{2}{*}{2008} & -.003 & -.025 & .064 & -.044 & -.236 & .120 & .825 & $-1.003^{*}$ \\
\hline & $(.214)$ & $(.143)$ & $(.172)$ & $(.191)$ & (.189) & $(.824)$ & $(1.088)$ & $(.532)$ \\
\hline \multirow[t]{2}{*}{ Constant } & $1.898^{\star *}$ & .539 & $1.450^{\star \star}$ & .583 & $7.083^{\star \star \star}$ & $6.806^{* * *}$ & $7.467^{* * *}$ & $6.879^{* * *}$ \\
\hline & $(.788)$ & $(.370)$ & $(.618)$ & $(.405)$ & $(1.015)$ & $(1.266)$ & $(1.379)$ & $(1.362)$ \\
\hline No. of districts & 67 & 67 & 67 & 67 & 67 & 67 & 67 & 67 \\
\hline Observations & 324 & 324 & 324 & 324 & 329 & 329 & 329 & 329 \\
\hline No. of instruments & 17 & 19 & 18 & 18 & 17 & 19 & 18 & 18 \\
\hline Hansen test & .48 & .39 & .65 & .28 & .04 & .01 & .02 & .02 \\
\hline Diff.-in-Hansen test & .22 & .16 & .92 & .15 & .01 & .05 & .00 & .12 \\
\hline Arellano-Bond $\operatorname{ar}(1)$ & .01 & .01 & .01 & .01 & .04 & .03 & .06 & .06 \\
\hline Arellano-Bond $\operatorname{ar}(2)$ & .81 & .63 & .68 & .64 & .14 & .22 & .73 & .14 \\
\hline \multicolumn{9}{|c|}{$\begin{array}{l}\text { Notes: }^{a}(1) \text { and (5) use only internal instruments (second and longer lags of central government education/health expenditure); }{ }^{b}(2) \text { and (6) use both } \\
\text { internal and external (log population and distance from district capital to Lusaka) instruments; }{ }^{c}(3) \text { and (7) use internal and one external (log population) } \\
\text { instrument; }{ }^{d}(4) \text { and (8) use internal and one external (distance to Lusaka) instrument. }\end{array}$} \\
\hline
\end{tabular}


Table E 13: System GMM health total expenditure-Hosp_OPDStaffpc

\begin{tabular}{|c|c|c|c|c|c|c|c|c|}
\hline & & d depen & iable as & & with & ged depe & ariable a & ssor \\
\hline & $(1)^{a}$ & $(2)^{b}$ & $(3)^{c}$ & $(4)^{d}$ & $(5)^{a}$ & $(6)^{b}$ & $(7)^{c}$ & $(8)^{d}$ \\
\hline ELF-E & $\begin{array}{l}-.001 \\
(.149)\end{array}$ & $\begin{array}{l}-.065 \\
(.087)\end{array}$ & $\begin{array}{l}-.084 \\
(.092)\end{array}$ & $\begin{array}{c}.001 \\
(.141)\end{array}$ & $\begin{array}{l}-.098 \\
(.253)\end{array}$ & $\begin{array}{c}.140 \\
(.347)\end{array}$ & $\begin{array}{l}.166 \\
(.359)\end{array}$ & $\begin{array}{l}-.086 \\
(.246)\end{array}$ \\
\hline $\begin{array}{l}\text { Hosp_OPDStaffpc } \\
\text { t-1 }\end{array}$ & .398 & $.866^{\star \star * t}$ & $.878^{* * x+}$ & .402 & & & & \\
\hline & $(.522)$ & $(.171)$ & $(.184)$ & $(.487)$ & & & & \\
\hline Expenditure & $\begin{array}{c}.031 \\
(.023)\end{array}$ & $\begin{array}{l}-.002 \\
(.016)\end{array}$ & $\begin{array}{l}-.003 \\
(.019)\end{array}$ & $\begin{array}{c}.032 \\
(.023)\end{array}$ & $\begin{array}{l}.040^{*} \\
(.022)\end{array}$ & $\begin{array}{l}-.014 \\
(.033)\end{array}$ & $\begin{array}{l}-.023 \\
(.031)\end{array}$ & $\begin{array}{l}.042^{*} \\
(.022)\end{array}$ \\
\hline Rural & $\begin{array}{c}-.124 \\
(.206)\end{array}$ & $\begin{array}{c}-.044 \\
(.143)\end{array}$ & $\begin{array}{c}-.050 \\
(.168)\end{array}$ & $\begin{array}{l}-.120 \\
(.202)\end{array}$ & $\begin{array}{l}-.315^{* *} \\
(.144)\end{array}$ & $\begin{array}{c}-.490^{* *} \\
(.236)\end{array}$ & $\begin{array}{l}-.522^{* *} \\
(.242)\end{array}$ & $\begin{array}{l}-.301^{\text {** }} \\
(.136)\end{array}$ \\
\hline Area (1000 km2) & $\begin{array}{l}-.004 \\
(.005)\end{array}$ & $\begin{array}{l}.001 \\
(.002)\end{array}$ & $\begin{array}{l}.001 \\
(.003)\end{array}$ & $\begin{array}{l}-.004 \\
(.005)\end{array}$ & $\begin{array}{l}-.005 \\
(.005)\end{array}$ & $\begin{array}{l}-.006 \\
(.007)\end{array}$ & $\begin{array}{l}-.006 \\
(.007)\end{array}$ & $\begin{array}{l}-.005 \\
(.005)\end{array}$ \\
\hline Poverty & $\begin{array}{l}-.517 \\
(.309)\end{array}$ & $\begin{array}{l}-.098 \\
(.181)\end{array}$ & $\begin{array}{l}-.114 \\
(.188)\end{array}$ & $\begin{array}{l}-.518^{*} \\
(.307)\end{array}$ & $\begin{array}{l}-.892^{*+\alpha} \\
(.297)\end{array}$ & $\begin{array}{l}-.639 \\
(.398)\end{array}$ & $\begin{array}{l}-.618 \\
(.404)\end{array}$ & $\begin{array}{l}-.882^{*+k} \\
(.304)\end{array}$ \\
\hline 2005 & $\begin{array}{l}.002 \\
(.092)\end{array}$ & $\begin{array}{l}.076 \\
. .051)\end{array}$ & $\begin{array}{l}.085 \\
.051)\end{array}$ & $\begin{array}{l}-.002 \\
(.087)\end{array}$ & $\begin{array}{l}-.034 \\
(.027)\end{array}$ & $\begin{array}{l}.007 \\
.037)\end{array}$ & $\begin{array}{l}.011 \\
.037)\end{array}$ & $\begin{array}{l}-.035 \\
(.027)\end{array}$ \\
\hline 2006 & $\begin{array}{l}-.107 \\
(.142)\end{array}$ & $\begin{array}{l}.070 \\
(.084)\end{array}$ & $\begin{array}{l}.084 \\
(.090)\end{array}$ & $\begin{array}{l}-.110 \\
(.139)\end{array}$ & $\begin{array}{l}-.164^{*+} \\
(.081)\end{array}$ & $\begin{array}{l}.047 \\
(.121)\end{array}$ & $\begin{array}{l}.082 \\
(.117)\end{array}$ & $\begin{array}{l}-.170^{* *} \\
(.076)\end{array}$ \\
\hline 2007 & $\begin{array}{l}-.107 \\
(.122)\end{array}$ & $\begin{array}{l}.064 \\
(.076)\end{array}$ & $\begin{array}{l}.074 \\
(.086)\end{array}$ & $\begin{array}{l}-.110 \\
(.120)\end{array}$ & $\begin{array}{l}-.154^{*} \\
(.083)\end{array}$ & $\begin{array}{l}.067 \\
(.147)\end{array}$ & $\begin{array}{l}.113 \\
(.147)\end{array}$ & $\begin{array}{l}-.159^{* *} \\
(.079)\end{array}$ \\
\hline 2008 & $\begin{array}{l}-.201 \\
(.189)\end{array}$ & $\begin{array}{l}.072 \\
(.116)\end{array}$ & $\begin{array}{l}.083 \\
(.134)\end{array}$ & $\begin{array}{l}-.207 \\
(.191)\end{array}$ & $\begin{array}{l}-.302^{* *} \\
(.140)\end{array}$ & $\begin{array}{l}.075 \\
(.218)\end{array}$ & $\begin{array}{l}.139 \\
(.210)\end{array}$ & $\begin{array}{l}-.315^{* *} \\
(.129)\end{array}$ \\
\hline Constant & $\begin{array}{r}.838 \\
(.756) \\
\end{array}$ & $\begin{array}{c}.121 \\
(.314)\end{array}$ & $\begin{array}{c}.122 \\
(.345) \\
(.35)\end{array}$ & $\begin{array}{c}.832 \\
(.724)\end{array}$ & $\begin{array}{c}1.556^{* \star \star} \\
(.301)\end{array}$ & $\begin{array}{c}1.478^{* \star \star} \\
(.372)\end{array}$ & $\begin{array}{c}1.487^{* \star *} \\
(.382)\end{array}$ & $\begin{array}{c}1.537^{* \star *} \\
(.293)\end{array}$ \\
\hline No. of districts & 52 & 52 & 52 & 52 & 53 & 53 & 53 & 53 \\
\hline Observations & 250 & 250 & 250 & 250 & 255 & 255 & 255 & 255 \\
\hline No. of instruments & 17 & 19 & 18 & 18 & 17 & 19 & 18 & 18 \\
\hline Hansen test & .29 & .15 & .10 & .41 & .46 & .04 & .02 & .58 \\
\hline Diff.-in-Hansen test & .06 & .03 & .01 & 19 & .14 & .00 & .00 & .21 \\
\hline Arellano-Bond $\operatorname{ar}(1)$ & .31 & .05 & .06 & .29 & .05 & .19 & .20 & .05 \\
\hline Arellano-Bond ar(2) & .15 & .11 & .11 & .16 & .23 & .12 & .11 & .24 \\
\hline $\begin{array}{l}\text { Notes: }{ }^{a}(1) \text { and (5) u } \\
\text { internal and external } \\
\text { instrument; }{ }^{d}(4) \text { and }\end{array}$ & $\begin{array}{l}y \text { inte } \\
\text { pulat } \\
\text { e inte }\end{array}$ & le ext & ance & $\begin{array}{l}\text { f cen } \\
\text { ka) ir } \\
\text { instru }\end{array}$ & $\begin{array}{l}\text { nent } \\
{ }^{c}(3)\end{array}$ & $\begin{array}{l}\text { healt } \\
\text { inter }\end{array}$ & $\begin{array}{l}\mathrm{re}){ }^{b} \\
\text { exte }\end{array}$ & $\begin{array}{l}\text { ) use } \\
\text { opula }\end{array}$ \\
\hline
\end{tabular}


Table E 14: System GMM education per capita expenditure-primary school enrolment

\begin{tabular}{|c|c|c|c|c|c|c|c|c|}
\hline & \multicolumn{4}{|c|}{ with lagged dependent variable as regressor } & \multicolumn{4}{|c|}{ without lagged dependent variable as regressor } \\
\hline & $(1)^{a}$ & $(2)^{b}$ & $(3)^{c}$ & $(4)^{d}$ & $(5)^{a}$ & $(6)^{b}$ & $(7)^{c}$ & $(8)^{d}$ \\
\hline \multirow[t]{2}{*}{ ELF-E } & .040 & $.047^{\star}$ & .044 & .044 & .207 & .236 & .230 & .212 \\
\hline & $(.030)$ & $(.027)$ & $(.027)$ & $(.031)$ & $(.156)$ & $(.142)$ & $(.149)$ & $(.147)$ \\
\hline \multirow{2}{*}{$\begin{array}{ll}\text { primary } & \text { school } \\
\text { enrolment } \sim \mathrm{t}-1 & \end{array}$} & $.911^{\star \star \star}$ & $.905^{\star \star \star}$ & $.913^{\star \star \star}$ & $.904^{\star \star \star *}$ & & & & \\
\hline & $(.054)$ & $(.047)$ & $(.049)$ & $(.053)$ & & & & \\
\hline \multirow[t]{2}{*}{ Expenditure p.c. } & $.317^{\star \star}$ & $.338^{* \star}$ & $.309^{* \star}$ & $.336^{\star \star}$ & $1.368^{\star \star \star}$ & $1.567^{\star \star \star}$ & $1.579^{\star \star \star}$ & $1.360^{\star \star \star}$ \\
\hline & $(.147)$ & $(.138)$ & $(.143)$ & $(.149)$ & $(.416)$ & $(.467)$ & $(.476)$ & $(.416)$ \\
\hline \multirow[t]{2}{*}{ Rural } & .006 & .005 & .006 & .005 & .046 & .046 & .045 & .047 \\
\hline & $(.009)$ & $(.009)$ & $(.009)$ & $(.009)$ & $(.046)$ & $(.046)$ & $(.046)$ & $(.046)$ \\
\hline \multirow[t]{2}{*}{ Area (1000 km2) } & -.000 & .000 & -.000 & .000 & .003 & .004 & .003 & .003 \\
\hline & $(.001)$ & $(.001)$ & $(.001)$ & $(.001)$ & $(.003)$ & $(.003)$ & $(.003)$ & $(.003)$ \\
\hline \multirow[t]{2}{*}{ Poverty } & .005 & -.002 & .001 & .002 & -.160 & -.139 & -.141 & -.159 \\
\hline & $(.044)$ & $(.043)$ & $(.042)$ & $(.045)$ & $(.177)$ & $(.170)$ & $(.170)$ & $(.177)$ \\
\hline \multirow[t]{2}{*}{2005} & $.326^{\star \star \star}$ & $.328^{\star \star \star}$ & $.329^{\star \star \star}$ & $.326^{* \star \star}$ & $.288^{\star \star \star *}$ & $.286^{\star \star \star}$ & $.286^{\star \star \star *}$ & $.289^{\star \star \star}$ \\
\hline & $(.017)$ & $(.018)$ & $(.017)$ & $(.018)$ & $(.022)$ & $(.023)$ & $(.023)$ & $(.022)$ \\
\hline \multirow[t]{2}{*}{2006} & .018 & $.019^{*}$ & .018 & .019 & $.230^{\star \star \star *}$ & $.222^{\star \star \star}$ & $.222^{\star \star \star}$ & $.231^{\star \star \star}$ \\
\hline & $(.014)$ & $(.011)$ & $(.011)$ & $(.014)$ & $(.024)$ & $(.024)$ & $(.024)$ & $(.024)$ \\
\hline \multirow[t]{2}{*}{2007} & $.159^{\star \star \star}$ & $.161^{\star \star \star}$ & $.159^{\star \star \star}$ & $.161^{\star \star \star}$ & $.350^{\star * *}$ & $.339^{\star \star \star}$ & $.339^{\star \star \star \star}$ & $.350^{\star \star \star *}$ \\
\hline & $(.017)$ & $(.016)$ & $(.016)$ & $(.017)$ & $(.032)$ & $(.031)$ & $(.031)$ & $(.032)$ \\
\hline \multirow[t]{2}{*}{2008} & -.006 & -.006 & -.006 & -.005 & $.248^{\star \star \star}$ & $.229^{\star \star \star}$ & $.228^{\star \star \star}$ & $.249^{\star \star \star}$ \\
\hline & $(.019)$ & $(.014)$ & $(.013)$ & $(.019)$ & $(.047)$ & $(.046)$ & $(.046)$ & $(.047)$ \\
\hline \multirow[t]{2}{*}{2009} & .034 & $.032^{*}$ & $.035^{*}$ & .033 & $.253^{* \star *}$ & $.229^{\star \star \star}$ & $.228^{* \star *}$ & $.254^{\star \star \star}$ \\
\hline & $(.025)$ & $(.019)$ & $(.019)$ & $(.026)$ & $(.050)$ & $(.051)$ & $(.052)$ & $(.050)$ \\
\hline \multirow[t]{2}{*}{ Constant } & .029 & .035 & .029 & .035 & $.848^{\star \star \star}$ & $.820^{\star \star \star}$ & $.824^{\star \star \star}$ & $.845^{\star \star \star}$ \\
\hline & $(.059)$ & $(.051)$ & $(.052)$ & $(.058)$ & $(.154)$ & $(.148)$ & $(.150)$ & $(.151)$ \\
\hline No. of districts & 68 & 68 & 68 & 68 & 68 & 68 & 68 & 68 \\
\hline Observations & 408 & 408 & 408 & 408 & 408 & 408 & 408 & 408 \\
\hline No. of instruments & 20 & 22 & 21 & 21 & 20 & 22 & 21 & 21 \\
\hline Hansen test & .09 & 12 & .11 & .11 & .00 & .01 & .00 & .00 \\
\hline Diff.-in-Hansen test & .51 & .75 & .89 & .37 & .00 & .00 & .00 & .00 \\
\hline Arellano-Bond $\operatorname{ar}(1)$ & .00 & .00 & .00 & .00 & .07 & .06 & .06 & .07 \\
\hline Arellano-Bond $\operatorname{ar}(2)$ & .23 & .23 & .23 & .23 & .64 & .58 & .58 & .64 \\
\hline \multicolumn{9}{|c|}{$\begin{array}{l}\text { Notes: }{ }^{a}(1) \text { and (5) use only internal instruments (second and longer lags of central government education/health expenditure); }{ }^{b}(2) \text { and }(6) \text { use both internal and } \\
\text { external (log population and distance from district capital to Lusaka) instruments; }{ }^{c}(3) \text { and (7) use internal and one external (log population) instrument; }{ }^{d}(4) \text { and (8) } \\
\text { use internal and one external (distance to Lusaka) instrument. }\end{array}$} \\
\hline
\end{tabular}


Table E 15: System GMM education per capita expenditure-lower secondary school enrolment

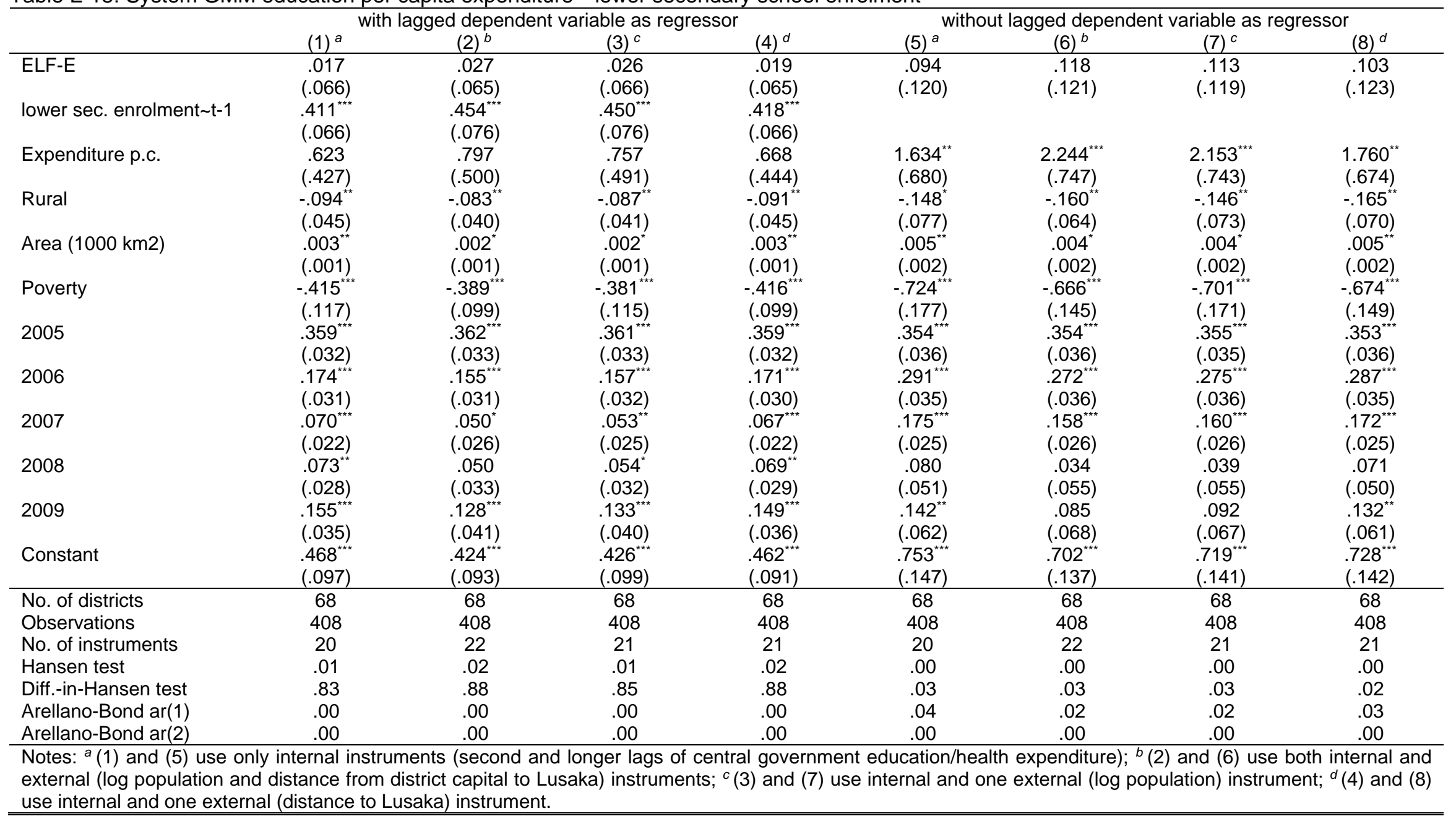


Table E 16: System GMM health per capita expenditure-maternal mortality

\begin{tabular}{|c|c|c|c|c|c|c|c|c|}
\hline & \multicolumn{4}{|c|}{ with lagged dependent variable as regressor } & \multicolumn{4}{|c|}{ without lagged dependent variable as regressor } \\
\hline & $(1)^{a}$ & $(2)^{b}$ & $(3)^{c}$ & $(4)^{d}$ & $(5)^{a}$ & $(6)^{b}$ & $(7)^{c}$ & $(8)^{d}$ \\
\hline ELF-E & $\begin{array}{c}-53.913 \\
(109.319)\end{array}$ & $\begin{array}{l}-2.377 \\
(90.677)\end{array}$ & $\begin{array}{l}-42.195 \\
(94.158)\end{array}$ & $\begin{array}{l}-20.029 \\
(90.588)\end{array}$ & $\begin{array}{l}-69.613 \\
(86.252)\end{array}$ & $\begin{array}{l}-39.841 \\
(84.763)\end{array}$ & $\begin{array}{l}-62.971 \\
(84.858)\end{array}$ & $\begin{array}{l}-49.836 \\
(87.584)\end{array}$ \\
\hline $\begin{array}{l}\text { maternalmortality } \sim \text { - } \\
1\end{array}$ & .028 & 271 & 109 & 176 & & & & \\
\hline & (.153) & $(.215)$ & $(.218)$ & $(.217)$ & & & & \\
\hline Expenditure p.c. & $\begin{array}{c}1309.305 \\
(5495.927)\end{array}$ & $\begin{array}{l}-1932.625 \\
(1185.571)\end{array}$ & $\begin{array}{c}1249.427 \\
(4442.971)\end{array}$ & $\begin{array}{l}-1789.740 \\
(1397.706)\end{array}$ & $\begin{array}{c}3190.549 \\
(3932.354)\end{array}$ & $\begin{array}{c}-1768.645^{\star \star} \\
(853.530)\end{array}$ & $\begin{array}{c}2000.955 \\
(4359.510)\end{array}$ & $\begin{array}{l}-1688.329 \\
(1068.291)\end{array}$ \\
\hline Rural & $\begin{array}{c}-105.953 \\
(91.817)\end{array}$ & $\begin{array}{c}-151.980^{*} \\
(80.078)\end{array}$ & $\begin{array}{l}-118.431 \\
(87.405)\end{array}$ & $\begin{array}{c}-163.595^{* \star} \\
(69.355)\end{array}$ & $\begin{array}{l}-58.362 \\
(76.308)\end{array}$ & $\begin{array}{c}-132.340^{* *} \\
(53.226)\end{array}$ & $\begin{array}{l}-75.078 \\
(74.830)\end{array}$ & $\begin{array}{c}-132.448^{* *} \\
(58.685)\end{array}$ \\
\hline Area $(1000 \mathrm{~km} 2)$ & $\begin{array}{l}.920 \\
(3.267)\end{array}$ & $\begin{array}{c}.255 \\
(1.990)\end{array}$ & $\begin{array}{c}.927 \\
(2.743)\end{array}$ & $\begin{array}{c}.449 \\
(2.177)\end{array}$ & $\begin{array}{c}-.261 \\
(2.722)\end{array}$ & $\begin{array}{l}-.113 \\
(2.507)\end{array}$ & $\begin{array}{c}-.631 \\
(2.739)\end{array}$ & $\begin{array}{l}-.213 \\
(2.342)\end{array}$ \\
\hline Poverty & $\begin{array}{c}368.435 \\
(246.582)\end{array}$ & $\begin{array}{c}289.273 \\
(196.275)\end{array}$ & $\begin{array}{l}392.485^{*} \\
(214.351)\end{array}$ & $\begin{array}{c}314.159 \\
(188.970)\end{array}$ & $\begin{array}{l}442.765^{\star *} \\
(202.384)\end{array}$ & $\begin{array}{c}224.806 \\
(172.983)\end{array}$ & $\begin{array}{l}410.145^{*} \\
(242.720)\end{array}$ & $\begin{array}{c}236.033 \\
(185.811)\end{array}$ \\
\hline 2005 & $\begin{array}{l}-21.796 \\
(76.984)\end{array}$ & $\begin{array}{l}24.708 \\
(65.725)\end{array}$ & $\begin{array}{c}8.259 \\
(43.091)\end{array}$ & $\begin{array}{l}18.671 \\
(42.103)\end{array}$ & $\begin{array}{l}-36.026 \\
(26.947)\end{array}$ & $\begin{array}{c}-8.741 \\
(26.621)\end{array}$ & $\begin{array}{l}-28.010 \\
(27.832)\end{array}$ & $\begin{array}{l}-16.301 \\
(26.247)\end{array}$ \\
\hline 2006 & $\begin{array}{l}-40.895 \\
(90.160)\end{array}$ & $\begin{array}{l}73.624 \\
(58.559)\end{array}$ & $\begin{array}{l}-7.570 \\
(92.590)\end{array}$ & $\begin{array}{c}62.559 \\
(44.722)\end{array}$ & $\begin{array}{l}-80.317 \\
(84.755)\end{array}$ & $\begin{array}{l}37.115 \\
(29.465)\end{array}$ & $\begin{array}{l}-43.528 \\
(86.020)\end{array}$ & $\begin{array}{l}27.814 \\
(30.366)\end{array}$ \\
\hline 2007 & $\begin{array}{c}-92.984 \\
(151.275)\end{array}$ & $\begin{array}{l}66.511 \\
(75.104)\end{array}$ & $\begin{array}{c}-60.088 \\
(143.817)\end{array}$ & $\begin{array}{c}58.850 \\
(62.998)\end{array}$ & $\begin{array}{l}-158.024 \\
(125.092)\end{array}$ & $\begin{array}{c}40.397 \\
(45.665)\end{array}$ & $\begin{array}{l}-102.948 \\
(133.592)\end{array}$ & $\begin{array}{l}31.603 \\
(50.354)\end{array}$ \\
\hline 2008 & $\begin{array}{l}-47.897 \\
(187.269)\end{array}$ & $\begin{array}{l}109.476 \\
(79.470)\end{array}$ & $\begin{array}{c}-16.375 \\
(161.053)\end{array}$ & $\begin{array}{l}104.366 \\
(64.821)\end{array}$ & $\begin{array}{l}-119.127 \\
(138.511)\end{array}$ & $\begin{array}{c}66.410 \\
(44.154)\end{array}$ & $\begin{array}{l}-78.780 \\
(141.051)\end{array}$ & $\begin{array}{l}63.387 \\
(49.323)\end{array}$ \\
\hline Constant & $\begin{array}{c}81.241 \\
(300.985)\end{array}$ & $\begin{array}{c}73.043 \\
(162.978)\end{array}$ & $\begin{array}{c}18.652 \\
(221.357)\end{array}$ & $\begin{array}{c}94.095 \\
(152.419)\end{array}$ & $\begin{array}{c}22.833 \\
(170.982)\end{array}$ & $\begin{array}{c}207.155^{*} \\
(110.786)\end{array}$ & $\begin{array}{c}51.618 \\
(200.304)\end{array}$ & $\begin{array}{l}212.158^{*} \\
(121.011)\end{array}$ \\
\hline No. of districts & 67 & 67 & 67 & 67 & 67 & 67 & 67 & 67 \\
\hline Observations & 306 & 306 & 306 & 306 & 320 & 320 & 320 & 320 \\
\hline No. of instruments & 17 & 19 & 18 & 18 & 17 & 19 & 18 & 18 \\
\hline Hansen test & .39 & .37 & .25 & .31 & .63 & .32 & .46 & .31 \\
\hline Diff.-in-Hansen test & .52 & .55 & .29 & .65 & .54 & .35 & .30 & .41 \\
\hline Arellano-Bond $\operatorname{ar}(1)$ & .06 & .08 & .11 & .11 & .01 & .02 & .02 & .02 \\
\hline Arellano-Bond ar(2) & .56 & .67 & .62 & .62 & .57 & .46 & .52 & .45 \\
\hline $\begin{array}{l}\text { Notes: }{ }^{a}(1) \text { and (5) u } \\
\text { internal and external } \\
\text { instrument; }{ }^{d}(4) \text { and }\end{array}$ & e intern & ne exte & tance tc & instru & nent $\mathrm{e}$ & /health & re) & $\begin{array}{l}\text { (6) use bot } \\
\text { population }\end{array}$ \\
\hline
\end{tabular}


Table E 17: System GMM health per capita expenditure-under 5 mortality

\begin{tabular}{|c|c|c|c|c|c|c|c|c|}
\hline & \multicolumn{4}{|c|}{ with lagged dependent variable as regressor } & \multicolumn{4}{|c|}{ without lagged dependent variable as regressor } \\
\hline & $(1)^{a}$ & $(2)^{b}$ & $(3)^{c}$ & $(4)^{d}$ & $(5)^{a}$ & $(6)^{b}$ & $(7)^{c}$ & $(8)^{d}$ \\
\hline ELF-E & $\begin{array}{l}-10.607 \\
(12885)\end{array}$ & $\begin{array}{l}-8.796 \\
(7562)\end{array}$ & $\begin{array}{c}-9.436 \\
(11.486)\end{array}$ & $\begin{array}{l}-9.014 \\
(8.064)\end{array}$ & -10.672 & -21.337 & -12.679 & -19.911 \\
\hline under5mortality -t-1 & $\begin{array}{c}(12.885) \\
.443 \\
(.342)\end{array}$ & $\begin{array}{l}(7.562) \\
.550^{* *} \\
(.274)\end{array}$ & $\begin{array}{c}(11.486) \\
.430 \\
(.296)\end{array}$ & $\begin{array}{c}(8.064) \\
.569^{*} \\
(.289)\end{array}$ & $(16.666)$ & $(18.181)$ & (16.446) & \\
\hline Expenditure p.c. & $\begin{array}{r}-187.441 \\
(622.739)\end{array}$ & $\begin{array}{l}-129.070 \\
(534.303)\end{array}$ & $\begin{array}{c}-181.273 \\
(562.898)\end{array}$ & $\begin{array}{l}-177.233 \\
(547.999)\end{array}$ & $\begin{array}{c}97.830 \\
(304.236)\end{array}$ & $\begin{array}{c}318.560 \\
(313.406)\end{array}$ & $\begin{array}{c}37.653 \\
(294.314)\end{array}$ & $\begin{array}{c}377.311 \\
(333.156)\end{array}$ \\
\hline Rural & $\begin{array}{c}-8.627 \\
(12.644)\end{array}$ & $\begin{array}{c}-6.805 \\
(11.107)\end{array}$ & $\begin{array}{c}-8.583 \\
(12.086)\end{array}$ & $\begin{array}{c}-7.685 \\
(10.798)\end{array}$ & $\begin{array}{c}-7.988 \\
(10.136)\end{array}$ & $\begin{array}{c}-6.080 \\
(12.505)\end{array}$ & $\begin{array}{c}-8.867 \\
(10.196)\end{array}$ & $\begin{array}{c}-5.048 \\
(12.881)\end{array}$ \\
\hline Area $(1000 \mathrm{~km} 2)$ & $\begin{array}{l}-.174 \\
(.240)\end{array}$ & $\begin{array}{l}-.122 \\
(.250)\end{array}$ & $\begin{array}{l}-.129 \\
(.239)\end{array}$ & $\begin{array}{l}-.152 \\
(.255)\end{array}$ & $\begin{array}{l}-.314 \\
(.373)\end{array}$ & $\begin{array}{l}-.479 \\
(.290)\end{array}$ & $\begin{array}{l}-.378 \\
(.316)\end{array}$ & $\begin{array}{l}-.409 \\
(.340)\end{array}$ \\
\hline Poverty & $\begin{array}{c}-.187 \\
(31.958)\end{array}$ & $\begin{array}{c}-5.581 \\
(23.262)\end{array}$ & $\begin{array}{c}.041 \\
(28.502)\end{array}$ & $\begin{array}{c}-5.900 \\
(24.584)\end{array}$ & $\begin{array}{c}30.545 \\
(25.100)\end{array}$ & $\begin{array}{c}35.771 \\
(25.666)\end{array}$ & $\begin{array}{c}31.405 \\
(25.571)\end{array}$ & $\begin{array}{c}34.291 \\
(25.325)\end{array}$ \\
\hline 2005 & $\begin{array}{c}15.314 \\
(12.213)\end{array}$ & $\begin{array}{l}17.912^{*} \\
(9.313)\end{array}$ & $\begin{array}{l}14.214 \\
(9.717)\end{array}$ & $\begin{array}{c}19.685^{\star} \\
(10.763)\end{array}$ & $\begin{array}{c}.190 \\
(3.344)\end{array}$ & $\begin{array}{c}-.261 \\
(3.482)\end{array}$ & $\begin{array}{c}.486 \\
(3.294)\end{array}$ & $\begin{array}{c}-.514 \\
(3.549)\end{array}$ \\
\hline 2006 & $\begin{array}{c}8.399 \\
(14.558)\end{array}$ & $\begin{array}{c}9.603 \\
(14.306)\end{array}$ & $\begin{array}{c}8.394 \\
(12.528)\end{array}$ & $\begin{array}{c}10.811 \\
(15.599)\end{array}$ & $\begin{array}{l}-7.761 \\
(8.382)\end{array}$ & $\begin{array}{c}-15.586^{*} \\
(8.392)\end{array}$ & $\begin{array}{l}-6.785 \\
(7.858)\end{array}$ & $\begin{array}{c}-16.654^{*} \\
(8.396)\end{array}$ \\
\hline 2007 & $\begin{array}{c}11.039 \\
(30.661)\end{array}$ & $\begin{array}{c}12.568 \\
(24.686)\end{array}$ & $\begin{array}{c}9.632 \\
(25.804)\end{array}$ & $\begin{array}{c}15.855 \\
(26.949)\end{array}$ & $\begin{array}{l}-15.282 \\
(9.294)\end{array}$ & $\begin{array}{c}-23.779^{* *} \\
(9.944)\end{array}$ & $\begin{array}{l}-13.128 \\
(8.792)\end{array}$ & $\begin{array}{l}-26.037^{* \star} \\
(10.769)\end{array}$ \\
\hline 2008 & $\begin{array}{c}3.359 \\
(41.604)\end{array}$ & $\begin{array}{c}4.752 \\
(34.754)\end{array}$ & $\begin{array}{c}2.184 \\
(36.037)\end{array}$ & $\begin{array}{c}8.413 \\
(36.831)\end{array}$ & $\begin{array}{l}-29.969^{* *} \\
(13.405)\end{array}$ & $\begin{array}{c}-41.357^{* * x} \\
(13.472)\end{array}$ & $\begin{array}{l}-27.075^{\star \star} \\
(12.717)\end{array}$ & $\begin{array}{c}-44.307^{\text {tox }} \\
(14.607)\end{array}$ \\
\hline Constant & $\begin{array}{l}34.153^{* *} \\
(15.536)\end{array}$ & $\begin{array}{c}25.393^{*} \\
(14.857) \\
\end{array}$ & $\begin{array}{l}34.575^{\star \star} \\
(15.219)\end{array}$ & $\begin{array}{c}24.432 \\
(15.352)\end{array}$ & $\begin{array}{l}55.836^{\star} \\
(22.648)\end{array}$ & $\begin{array}{l}57.157^{\star} \\
(24.503)\end{array}$ & $\begin{array}{l}57.539^{* \star} \\
(23.780)\end{array}$ & $\begin{array}{l}55.992^{* *} \\
(24.368)\end{array}$ \\
\hline No. of districts & 67 & 67 & 67 & 67 & 67 & 67 & 67 & 67 \\
\hline Observations & 324 & 324 & 324 & 324 & 329 & 329 & 329 & 329 \\
\hline No. of instruments & 17 & 19 & 18 & 18 & 17 & 19 & 18 & 18 \\
\hline Hansen test & .04 & 14 & .06 & .13 & .04 & .07 & .05 & .05 \\
\hline Diff.-in-Hansen test & .01 & .02 & .01 & .02 & .08 & .40 & .07 & .31 \\
\hline Arellano-Bond $\operatorname{ar}(1)$ & .15 & 13 & 14 & .13 & 18 & 17 & .18 & .17 \\
\hline Arellano-Bond ar(2) & .52 & .39 & .50 & .39 & .28 & .31 & .28 & .32 \\
\hline
\end{tabular}


Table E 18: System GMM health per capita expenditure-total beds per 1000

\begin{tabular}{|c|c|c|c|c|c|c|c|c|}
\hline & \multicolumn{4}{|c|}{ with lagged dependent variable as regressor } & \multicolumn{4}{|c|}{ without lagged dependent variable as regressor } \\
\hline & $(1)^{a}$ & $(2)^{b}$ & $(3)^{c}$ & $(4)^{d}$ & $(5)^{a}$ & $(6)^{b}$ & $(7)^{c}$ & $(8)^{d}$ \\
\hline \multirow[t]{2}{*}{ ELF-E } & $-.832^{*}$ & -.402 & -.491 & -.552 & $-1.667^{\star \star \star}$ & $-1.429^{*}$ & $-1.361^{\star *}$ & $-1.490^{\star * \star}$ \\
\hline & $(.419)$ & $(.271)$ & $(.332)$ & $(.414)$ & $(.624)$ & $(.735)$ & $(.680)$ & $(.541)$ \\
\hline \multirow[t]{2}{*}{ tbedspc $\sim \mathrm{t}-1$} & $.449^{* \star}$ & $.744^{\star * \star}$ & $.694^{\star \star \star}$ & $.633^{\star \star}$ & & & & \\
\hline & $(.172)$ & $(.125)$ & $(.150)$ & $(.279)$ & & & & \\
\hline \multirow[t]{2}{*}{ Expenditure p.c. } & 3.261 & 3.463 & 1.947 & 4.803 & .748 & $19.886^{\star}$ & 8.700 & 10.859 \\
\hline & (7.957) & $(7.300)$ & (7.332) & (8.307) & $(7.418)$ & (10.297) & (6.162) & (6.561) \\
\hline \multirow[t]{2}{*}{ Rural } & -.431 & -.220 & -.333 & -.252 & $-.865^{\star \star}$ & -.579 & $-.808^{* *}$ & $-.777^{\star \star}$ \\
\hline & $(.349)$ & $(.240)$ & $(.310)$ & $(.245)$ & $(.403)$ & $(.362)$ & (.396) & $(.364)$ \\
\hline \multirow[t]{2}{*}{ Area (1000 km2) } & .006 & .002 & .002 & .003 & .010 & .009 & .011 & .010 \\
\hline & $(.009)$ & (.006) & $(.007)$ & $(.007)$ & $(.017)$ & $(.017)$ & (.018) & (.016) \\
\hline \multirow[t]{2}{*}{ Poverty } & -.033 & -.014 & .073 & -.056 & -.369 & -.361 & -.328 & -.283 \\
\hline & $(.414)$ & $(.314)$ & $(.348)$ & $(.335)$ & $(.763)$ & (.838) & (.768) & $(.774)$ \\
\hline \multirow[t]{2}{*}{2005} & -.020 & .047 & .055 & .004 & -.080 & -.087 & -.069 & -.108 \\
\hline & $(.110)$ & (.119) & $(.115)$ & $(.152)$ & (.113) & $(.123)$ & $(.115)$ & $(.115)$ \\
\hline \multirow[t]{2}{*}{2006} & -.090 & -.089 & -.058 & -.127 & -.175 & $-.590^{* *}$ & $-.340^{*}$ & $-.407^{\star *}$ \\
\hline & $(.234)$ & $(.206)$ & $(.209)$ & $(.224)$ & $(.217)$ & $(.283)$ & (.195) & $(.195)$ \\
\hline \multirow[t]{2}{*}{2007} & -.107 & -.022 & .024 & -.108 & -.135 & $-.699^{* *}$ & -.364 & $-.447^{\star}$ \\
\hline & $(.285)$ & $(.284)$ & $(.277)$ & $(.362)$ & $(.257)$ & $(.338)$ & $(.225)$ & $(.227)$ \\
\hline \multirow[t]{2}{*}{2008} & -.260 & -.147 & -.090 & -.248 & -.202 & $-.940^{* *}$ & -.498 & $-.637^{\star *}$ \\
\hline & $(.395)$ & (.333) & $(.339)$ & (.439) & $(.347)$ & (.459) & $(.302)$ & $(.300)$ \\
\hline \multirow[t]{2}{*}{ Constant } & $1.764^{\star *}$ & $.760^{\star}$ & $.936^{*}$ & 1.126 & $3.606^{\star \star \star}$ & $3.247^{\star \star \star}$ & $3.368^{\star \star \star}$ & $3.414^{\star \star \star}$ \\
\hline & $(.693)$ & (.429) & $(.544)$ & $(.924)$ & $(.627)$ & $(.744)$ & $(.626)$ & $(.577)$ \\
\hline No. of districts & 67 & 67 & 67 & 67 & 67 & 67 & 67 & 67 \\
\hline Observations & 324 & 324 & 324 & 324 & 329 & 329 & 329 & 329 \\
\hline No. of instruments & 17 & 19 & 18 & 18 & 17 & 19 & 18 & 18 \\
\hline Hansen test & .14 & .16 & .14 & .09 & .10 & .06 & .09 & .10 \\
\hline Diff.-in-Hansen test & .12 & .66 & .53 & .68 & .06 & .92 & .37 & .53 \\
\hline Arellano-Bond ar(1) & .03 & .02 & .02 & .03 & .05 & .04 & .03 & .03 \\
\hline Arellano-Bond ar(2) & .20 & .14 & .15 & .17 & .88 & .38 & .52 & .48 \\
\hline
\end{tabular}


Table E 19: System GMM health per capita expenditure-BCG immunization rate

\begin{tabular}{|c|c|c|c|c|c|c|c|c|}
\hline & \multicolumn{4}{|c|}{ with lagged dependent variable as regressor } & \multicolumn{4}{|c|}{ without lagged dependent variable as regressor } \\
\hline & $(1)^{a}$ & $(2)^{b}$ & $(3)^{c}$ & $(4)^{d}$ & $(5)^{a}$ & $(6)^{b}$ & $(7)^{c}$ & $(8)^{d}$ \\
\hline \multirow[t]{2}{*}{ ELF-E } & $.162^{*}$ & .129 & .123 & $.149^{\star}$ & $.197^{\star \star}$ & .131 & .159 & .157 \\
\hline & $(.084)$ & $(.091)$ & $(.093)$ & (.088) & $(.093)$ & (.108) & $(.101)$ & (.110) \\
\hline \multirow{2}{*}{ BCGimmun t-1 } & .084 & .127 & .074 & .116 & & & & \\
\hline & $(.057)$ & (.109) & $(.067)$ & (.095) & & & & \\
\hline \multirow[t]{2}{*}{ Expenditure p.c. } & -.123 & 2.171 & -.243 & 2.469 & -1.518 & -1.001 & -1.541 & -1.004 \\
\hline & $(2.509)$ & (3.269) & $(2.786)$ & (3.029) & (2.293) & $(1.845)$ & $(2.547)$ & (1.911) \\
\hline \multirow[t]{2}{*}{ Rural } & .035 & .085 & .015 & .099 & -.005 & -.006 & -.016 & -.001 \\
\hline & $(.079)$ & (.102) & $(.083)$ & (.094) & $(.080)$ & (.094) & $(.084)$ & (.093) \\
\hline \multirow[t]{2}{*}{ Area (1000 km2) } & .002 & .002 & .003 & .001 & .002 & .002 & .003 & .002 \\
\hline & $(.003)$ & (.003) & $(.003)$ & (.003) & $(.003)$ & $(.004)$ & $(.004)$ & $(.004)$ \\
\hline \multirow[t]{2}{*}{ Poverty } & $.389^{\star \star \star}$ & $.329^{\star \star}$ & $.362^{\star \star \star}$ & $.336^{\star \star \star}$ & $.452^{\star \star \star}$ & $.396^{* \star}$ & $.423^{\star \star \star}$ & $.403^{\star \star \star}$ \\
\hline & $(.116)$ & (.128) & $(.129)$ & $(.125)$ & $(.125)$ & (.154) & $(.141)$ & (.148) \\
\hline \multirow[t]{2}{*}{2005} & -.037 & -.052 & -.028 & -.055 & -.014 & -.010 & -.009 & -.015 \\
\hline & $(.036)$ & (.048) & $(.038)$ & $(.047)$ & $(.027)$ & (.031) & $(.027)$ & $(.031)$ \\
\hline \multirow[t]{2}{*}{2006} & .014 & -.038 & .020 & -.042 & .044 & .045 & .050 & $.041^{\prime}$ \\
\hline & $(.060)$ & $(.084)$ & $(.067)$ & $(.081)$ & $(.052)$ & $(.047)$ & $(.057)$ & (.049) \\
\hline \multirow[t]{2}{*}{2007} & -.053 & -.128 & -.037 & -.143 & .004 & -.008 & .013 & -.014 \\
\hline & $(.085)$ & (.109) & $(.094)$ & $(.102)$ & $(.073)$ & $(.057)$ & $(.080)$ & $(.058)$ \\
\hline \multirow[t]{2}{*}{2008} & .005 & -.088 & .034 & -.115 & .078 & .071 & .097 & .060 \\
\hline & $(.123)$ & (.167) & $(.135)$ & (.155) & $(.110)$ & (.092) & $(.121)$ & (.095) \\
\hline \multirow[t]{2}{*}{ Constant } & $.771^{\star \star \star}$ & $.732^{\star \star \star}$ & $.816^{\star \star \star}$ & $.731^{\star \star \star}$ & $.845^{\star \star \star}$ & $.899^{\star \star \star}$ & $.873^{\star \star \star}$ & $.894^{\star \star \star}$ \\
\hline & $(.126)$ & $(.171)$ & $(.144)$ & (.158) & $(.118)$ & (.139) & $(.128)$ & $(.137)$ \\
\hline No. of districts & 67 & 67 & 67 & 67 & 67 & 67 & 67 & 67 \\
\hline Observations & 324 & 324 & 324 & 324 & 329 & 329 & 329 & 329 \\
\hline No. of instruments & 17 & 19 & 18 & 18 & 17 & 19 & 18 & 18 \\
\hline Hansen test & .42 & .05 & .26 & .04 & .74 & .18 & .65 & .16 \\
\hline Diff.-in-Hansen test & .51 & .53 & .75 & .05 & .38 & .65 & .94 & .08 \\
\hline Arellano-Bond ar(1) & .01 & .01 & .01 & .01 & .00 & .00 & .00 & .00 \\
\hline Arellano-Bond ar(2) & .46 & .44 & .55 & .44 & .94 & .96 & .94 & .96 \\
\hline
\end{tabular}


Table E 20: System GMM health per capita expenditure-DPT3 immunization rate

\begin{tabular}{|c|c|c|c|c|c|c|c|c|}
\hline & \multicolumn{4}{|c|}{ with lagged dependent variable as regressor } & \multicolumn{4}{|c|}{ without lagged dependent variable as regressor } \\
\hline & $(1)^{a}$ & $(2)^{b}$ & $(3)^{c}$ & $(4)^{d}$ & $(5)^{a}$ & $(6)^{b}$ & $(7)^{c}$ & $(8)^{d}$ \\
\hline \multirow[t]{2}{*}{ ELF-E } & $.168^{\star *}$ & .088 & $.142^{* \star}$ & $.097^{\star}$ & $.266^{\star \star \star}$ & $.311^{\star \star}$ & $.251^{\star *}$ & $.311^{* *}$ \\
\hline & $(.072)$ & $(.056)$ & $(.069)$ & $(.056)$ & $(.099)$ & $(.135)$ & $(.105)$ & $(.131)$ \\
\hline \multirow[t]{2}{*}{ DPT3immun $\sim \mathrm{t}-1$} & $.497^{\star \star \star}$ & $.724^{\star \star \star}$ & $.564^{\star \star \star}$ & $.703^{\star \star \star}$ & & & & \\
\hline & $(.160)$ & $(.090)$ & $(.166)$ & $(.089)$ & & & & \\
\hline \multirow[t]{2}{*}{ Expenditure p.c. } & -2.075 & -.960 & -2.262 & -.441 & $-3.386^{*}$ & -.373 & $-3.982^{\star *}$ & .507 \\
\hline & (1.908) & $(2.100)$ & $(2.074)$ & $(2.310)$ & (1.807) & (3.054) & $(1.809)$ & (2.909) \\
\hline \multirow[t]{2}{*}{ Rural } & -.012 & .003 & -.016 & .019 & -.021 & .117 & -.021 & .145 \\
\hline & $(.062)$ & $(.065)$ & (.059) & $(.071)$ & $(.072)$ & $(.125)$ & $(.076)$ & $(.124)$ \\
\hline \multirow[t]{2}{*}{ Area $(1000 \mathrm{~km} 2)$} & .001 & .000 & .001 & .000 & .003 & .002 & .004 & .001 \\
\hline & $(.002)$ & $(.001)$ & $(.002)$ & $(.001)$ & $(.003)$ & $(.004)$ & $(.004)$ & $(.004)$ \\
\hline \multirow[t]{2}{*}{ Poverty } & .154 & .071 & .126 & .077 & .258 & .164 & .220 & .146 \\
\hline & $(.112)$ & $(.078)$ & $(.102)$ & $(.079)$ & $(.167)$ & $(.219)$ & $(.182)$ & $(.210)$ \\
\hline \multirow[t]{2}{*}{2005} & -.002 & -.007 & -.001 & -.010 & .009 & .012 & .015 & .011 \\
\hline & $(.029)$ & $(.036)$ & $(.032)$ & $(.036)$ & $(.021)$ & $(.026)$ & $(.021)$ & $(.026)$ \\
\hline \multirow[t]{2}{*}{2006} & -.070 & $-.095^{*}$ & -.069 & $-.106^{*}$ & -.020 & -.075 & -.006 & -.097 \\
\hline & $(.044)$ & $(.052)$ & $(.047)$ & $(.056)$ & $(.039)$ & $(.080)$ & $(.037)$ & $(.083)$ \\
\hline \multirow[t]{2}{*}{2007} & -.069 & -.080 & -.055 & -.103 & -.056 & -.135 & -.040 & -.164 \\
\hline & $(.064)$ & $(.078)$ & $(.068)$ & $(.087)$ & $(.052)$ & $(.109)$ & $(.048)$ & $(.113)$ \\
\hline \multirow[t]{2}{*}{2008} & .084 & .073 & .105 & .044 & .063 & -.040 & .094 & -.077 \\
\hline & $(.083)$ & $(.097)$ & $(.086)$ & (.109) & $(.082)$ & $(.128)$ & $(.081)$ & $(.120)$ \\
\hline \multirow[t]{2}{*}{ Constant } & $.455^{\star \star \star}$ & $.262^{* \star *}$ & $.408^{* \star}$ & $.267^{\star \star * \star}$ & $.907^{\star \star \star}$ & $.828^{\star \star \star}$ & $.932^{\star \star \star *}$ & $.818^{\star \star \star *}$ \\
\hline & $(.170)$ & $(.090)$ & $(.175)$ & $(.091)$ & $(.148)$ & $(.176)$ & $(.158)$ & $(.164)$ \\
\hline No. of districts & 67 & 67 & 67 & 67 & 67 & 67 & 67 & 67 \\
\hline Observations & 324 & 324 & 324 & 324 & 329 & 329 & 329 & 329 \\
\hline No. of instruments & 17 & 19 & 18 & 18 & 17 & 19 & 18 & 18 \\
\hline Hansen test & .24 & .23 & .26 & .19 & .23 & .00 & .25 & .00 \\
\hline Diff.-in-Hansen test & .15 & .24 & .24 & .16 & .94 & .06 & .92 & .04 \\
\hline Arellano-Bond $\operatorname{ar}(1)$ & .00 & .00 & .00 & .00 & .00 & .00 & .00 & .00 \\
\hline Arellano-Bond $\operatorname{ar}(2)$ & .67 & .40 & .59 & .40 & .38 & .44 & .38 & .47 \\
\hline
\end{tabular}


Table E 21: System GMM health per capita expenditure-OPV3 immunization rate

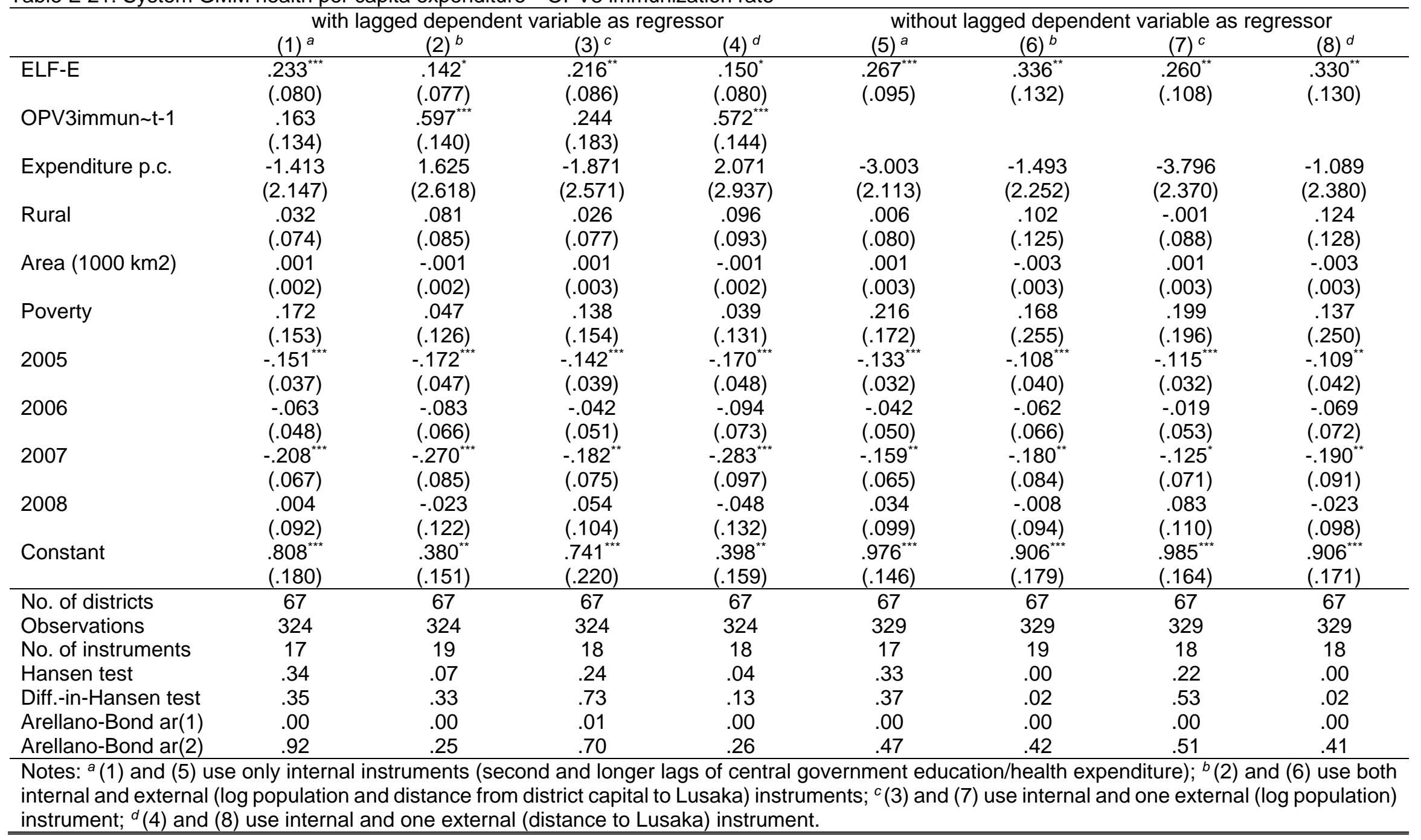


Table E 22: System GMM health per capita expenditure-measles immunization rate

\begin{tabular}{|c|c|c|c|c|c|c|c|c|}
\hline & \multicolumn{4}{|c|}{ with lagged dependent variable as regressor } & \multicolumn{4}{|c|}{ without lagged dependent variable as regressor } \\
\hline & $(1)^{a}$ & $(2)^{b}$ & $(3)^{c}$ & $(4)^{d}$ & $(5)^{a}$ & $(6)^{b}$ & $(7)^{c}$ & $(8)^{d}$ \\
\hline \multirow[t]{2}{*}{ ELF-E } & $.170^{*}$ & .151 & .144 & $.162^{*}$ & $.203^{*}$ & .189 & .166 & .211 \\
\hline & $(.094)$ & $(.100)$ & $(.101)$ & $(.094)$ & $(.109)$ & $(.153)$ & $(.127)$ & $(.143)$ \\
\hline \multirow[t]{2}{*}{ Measles $\sim \mathrm{t}-1$} & .116 & $.255^{\star \star}$ & $.169^{*}$ & $238^{* \star}$ & & & & \\
\hline & $(.081)$ & $(.114)$ & $(.100)$ & $(.106)$ & & & & \\
\hline \multirow[t]{2}{*}{ Expenditure p.c. } & .028 & .603 & -.119 & .806 & -1.272 & -.601 & -2.302 & .267 \\
\hline & $(1.307)$ & $(1.682)$ & $(1.511)$ & $(1.847)$ & (1.986) & $(2.023)$ & $(2.148)$ & $(1.622)$ \\
\hline \multirow[t]{2}{*}{ Rural } & .068 & .066 & .060 & .074 & .044 & .048 & .020 & .074 \\
\hline & $(.050)$ & $(.057)$ & $(.053)$ & $(.057)$ & $(.069)$ & $(.083)$ & $(.072)$ & $(.074)$ \\
\hline \multirow[t]{2}{*}{ Area $(1000 \mathrm{~km} 2)$} & .001 & .000 & .001 & -.000 & .001 & -.001 & .001 & -.002 \\
\hline & $(.003)$ & $(.003)$ & $(.003)$ & $(.003)$ & $(.004)$ & $(.005)$ & $(.004)$ & $(.005)$ \\
\hline \multirow[t]{2}{*}{ Poverty } & .177 & .155 & .164 & .147 & .237 & .302 & .247 & .263 \\
\hline & $(.148)$ & $(.141)$ & $(.148)$ & $(.145)$ & $(.186)$ & $(.237)$ & (.199) & $(.246)$ \\
\hline \multirow[t]{2}{*}{2005} & .013 & .012 & .016 & .009 & .017 & .018 & .023 & .012 \\
\hline & $(.021)$ & $(.025)$ & $(.023)$ & $(.023)$ & $(.020)$ & $(.023)$ & $(.021)$ & $(.023)$ \\
\hline \multirow[t]{2}{*}{2006} & $.053^{*}$ & .033 & .051 & .031 & $.075^{*}$ & .063 & $.094^{\star \star}$ & .048 \\
\hline & $(.030)$ & $(.040)$ & $(.035)$ & $(.044)$ & $(.038)$ & $(.039)$ & $(.043)$ & $(.032)$ \\
\hline \multirow[t]{2}{*}{2007} & .007 & -.008 & .010 & -.015 & .049 & .043 & .085 & .015 \\
\hline & $(.060)$ & $(.078)$ & $(.070)$ & $(.082)$ & $(.071)$ & $(.075)$ & $(.076)$ & $(.068)$ \\
\hline \multirow[t]{2}{*}{2008} & .037 & .024 & .052 & .005 & .098 & .084 & .148 & .041 \\
\hline & $(.063)$ & $(.077)$ & (.069) & $(.087)$ & $(.085)$ & $(.088)$ & $(.090)$ & $(.081)$ \\
\hline \multirow[t]{2}{*}{ Constant } & $.623^{\star \star \star}$ & $.519^{\star * \star}$ & $.598^{\star \star \star *}$ & $.538^{\star \star \star *}$ & $.718^{\star \star \star}$ & $.693^{\star \star \star *}$ & $.746^{\star \star \star *}$ & $.693^{\star \star *}$ \\
\hline & $(.111)$ & $(.116)$ & $(.118)$ & $(.118)$ & $(.122)$ & $(.156)$ & $(.140)$ & $(.157)$ \\
\hline No. of districts & 67 & 67 & 67 & 67 & 67 & 67 & 67 & 67 \\
\hline Observations & 324 & 324 & 324 & 324 & 329 & 329 & 329 & 329 \\
\hline No. of instruments & 17 & 19 & 18 & 18 & 17 & 19 & 18 & 18 \\
\hline Hansen test & .08 & .03 & .03 & .08 & .16 & .01 & .06 & .01 \\
\hline Diff.-in-Hansen test & .30 & .82 & .93 & .20 & .15 & .08 & .53 & .01 \\
\hline Arellano-Bond $\operatorname{ar}(1)$ & .00 & .00 & .00 & .00 & .00 & .00 & .00 & .00 \\
\hline Arellano-Bond $\operatorname{ar}(2)$ & .14 & .14 & .13 & .15 & .26 & .30 & .22 & .34 \\
\hline
\end{tabular}


Table E 23: System GMM health per capita expenditure-FIC immunization rate

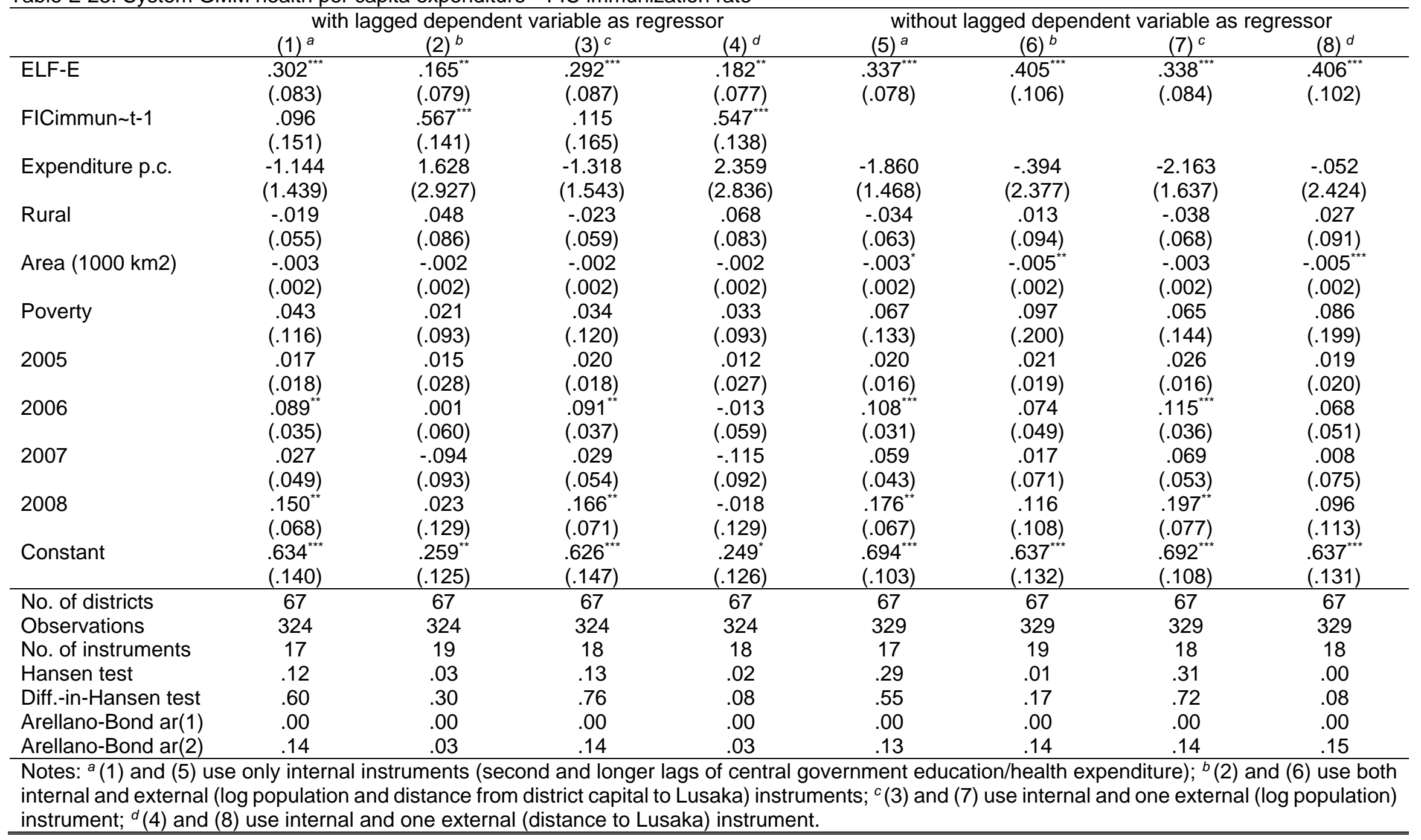


Table E 24: System GMM health per capita expenditure-underweight5

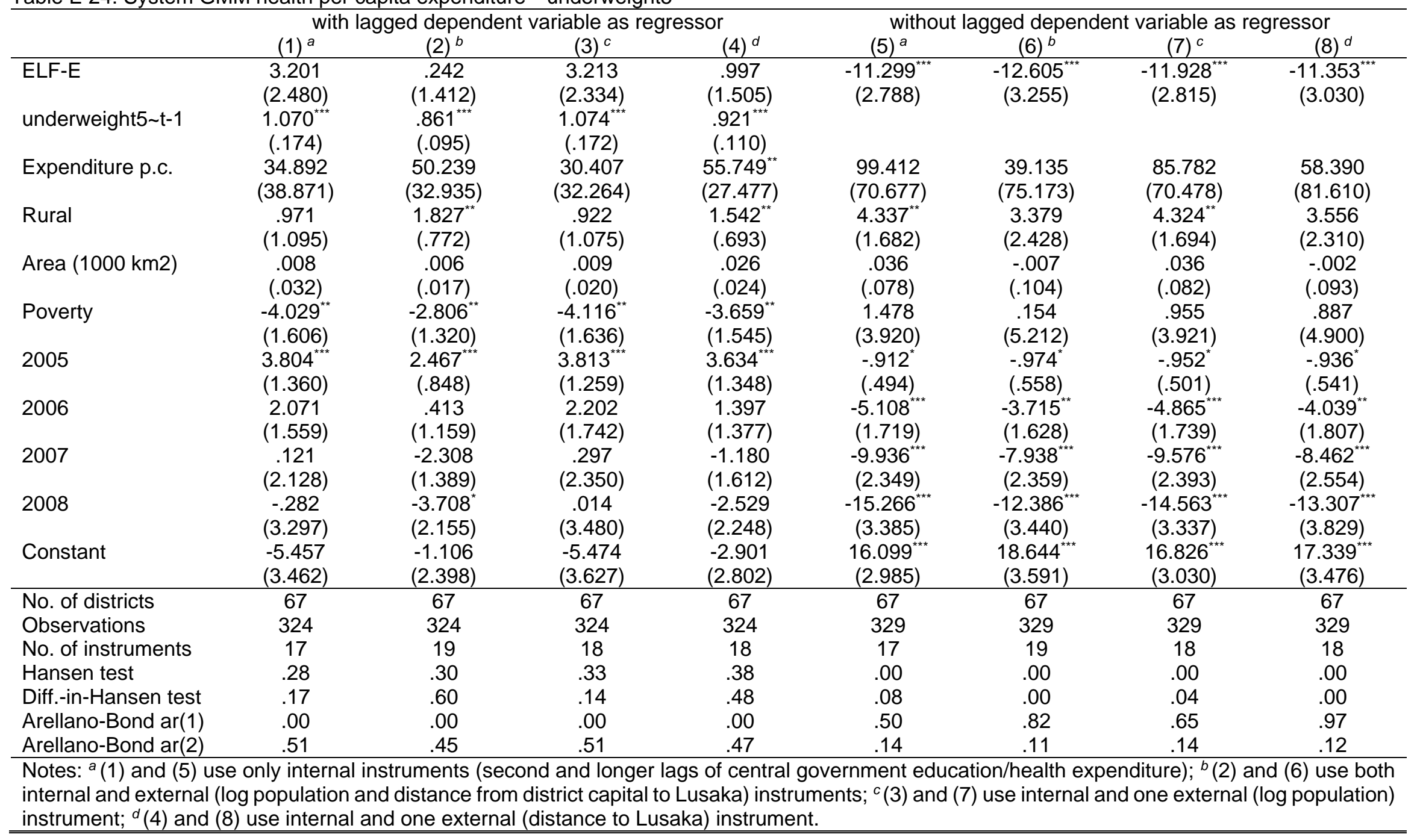


Table E 25: System GMM health per capita expenditure-HC_Staffpc

\begin{tabular}{|c|c|c|c|c|c|c|c|c|}
\hline & \multicolumn{4}{|c|}{ with lagged dependent variable as regressor } & \multicolumn{4}{|c|}{ without lagged dependent variable as regressor } \\
\hline & $(1)^{a}$ & $(2)^{b}$ & $(3)^{c}$ & $(4)^{d}$ & $(5)^{a}$ & $(6)^{b}$ & $(7)^{c}$ & $(8)^{d}$ \\
\hline ELF-E & $\begin{array}{l}.559 \\
(.424)\end{array}$ & $\begin{array}{l}.075 \\
(.242)\end{array}$ & $\begin{array}{c}.327 \\
(.380)\end{array}$ & $\begin{array}{l}.124 \\
(.288)\end{array}$ & $\begin{array}{l}2.884^{* *} \\
(1.271)\end{array}$ & $\begin{array}{l}2.895^{* *} \\
(1.376)\end{array}$ & $\begin{array}{l}2.932^{* *} \\
(1.232)\end{array}$ & $\begin{array}{l}3.123^{* *} \\
(1.388)\end{array}$ \\
\hline HC_Staffpc $\sim \mathrm{t}-1$ & $\begin{array}{l}.733^{*+x+x} \\
(.082)\end{array}$ & $\begin{array}{l}.910^{* * x+} \\
(.056)\end{array}$ & $\begin{array}{l}.831^{*+x} \\
(.093)\end{array}$ & $\begin{array}{l}.867^{*+\alpha} \\
(.059)\end{array}$ & & & & \\
\hline Expenditure p.c. & $\begin{array}{c}-2.665 \\
(10.955)\end{array}$ & $\begin{array}{c}.123 \\
(10.486)\end{array}$ & $\begin{array}{c}-.691 \\
(10.381)\end{array}$ & $\begin{array}{c}-.290 \\
(10.982)\end{array}$ & $\begin{array}{c}3.989 \\
(10.875)\end{array}$ & $\begin{array}{c}56.744^{*} \\
(28.545)\end{array}$ & $\begin{array}{c}16.488 \\
(17.485)\end{array}$ & $\begin{array}{l}40.193^{*} \\
(23.703)\end{array}$ \\
\hline Rural & $\begin{array}{c}-.334 \\
(.221)\end{array}$ & $\begin{array}{c}-.108 \\
(.227)\end{array}$ & $\begin{array}{l}-.226 \\
(.243)\end{array}$ & $\begin{array}{l}-.145 \\
(.212)\end{array}$ & $\begin{array}{c}-1.021^{*} \\
(.542)\end{array}$ & $\begin{array}{l}.046 \\
(.722)\end{array}$ & $\begin{array}{l}-.882 \\
(.559)\end{array}$ & $\begin{array}{c}-.124 \\
(.673)\end{array}$ \\
\hline Area $(1000 \mathrm{~km} 2)$ & $\begin{array}{l}-.014^{*} \\
(.008)\end{array}$ & $\begin{array}{l}-.004 \\
(.006)\end{array}$ & $\begin{array}{l}-.009 \\
(.008)\end{array}$ & $\begin{array}{l}-.007 \\
(.006)\end{array}$ & $\begin{array}{l}-.063^{* *} \\
(.026)\end{array}$ & $\begin{array}{l}-.080^{* * *} \\
(.025)\end{array}$ & $\begin{array}{l}-.069^{\ldots+k} \\
(.026)\end{array}$ & $\begin{array}{l}-.075^{\star \star \star *} \\
(.025)\end{array}$ \\
\hline Poverty & $\begin{array}{l}-.646 \\
(.460)\end{array}$ & $\begin{array}{l}.014 \\
(.302)\end{array}$ & $\begin{array}{l}-.274 \\
(.415)\end{array}$ & $\begin{array}{l}-.141 \\
(.312)\end{array}$ & $\begin{array}{l}-3.164^{* *} \\
(1.472)\end{array}$ & $\begin{array}{c}-3.696^{* *} \\
(1.798)\end{array}$ & $\begin{array}{l}-3.170^{* *} \\
(1.486)\end{array}$ & $\begin{array}{l}-3.724^{* *} \\
(1.841)\end{array}$ \\
\hline 2005 & $\begin{array}{c}.052 \\
(.113)\end{array}$ & $\begin{array}{c}.090 \\
(.133)\end{array}$ & $\begin{array}{c}.084 \\
(.124)\end{array}$ & $\begin{array}{l}.072 \\
(.127)\end{array}$ & $\begin{array}{c}.012 \\
(.090)\end{array}$ & $\begin{array}{l}-.014 \\
(.110)\end{array}$ & $\begin{array}{c}.017 \\
(.093)\end{array}$ & $\begin{array}{l}-.006 \\
(.105)\end{array}$ \\
\hline 2006 & $\begin{array}{l}.101 \\
(.251)\end{array}$ & $\begin{array}{l}.042 \\
(.216)\end{array}$ & $\begin{array}{l}.039 \\
(.216)\end{array}$ & $\begin{array}{l}.068 \\
(.235)\end{array}$ & $\begin{array}{l}-.156 \\
(.270)\end{array}$ & $\begin{array}{c}-1.277^{\star *} \\
(.634)\end{array}$ & $\begin{array}{l}-.424 \\
(.410)\end{array}$ & $\begin{array}{l}-.913 \\
(.547)\end{array}$ \\
\hline 2007 & $\begin{array}{l}.250 \\
(.344)\end{array}$ & $\begin{array}{l}.178 \\
(.309)\end{array}$ & $\begin{array}{l}.181 \\
(.309)\end{array}$ & $\begin{array}{l}.225 \\
(.335)\end{array}$ & $\begin{array}{l}-.112 \\
(.355)\end{array}$ & $\begin{array}{c}-1.656^{*} \\
(.838)\end{array}$ & $\begin{array}{c}-.476 \\
(.541)\end{array}$ & $\begin{array}{l}-1.160 \\
(.718)\end{array}$ \\
\hline 2008 & $\begin{array}{l}-.123 \\
(.437)\end{array}$ & $\begin{array}{l}-.201 \\
(.414)\end{array}$ & $\begin{array}{l}-.185 \\
(.408)\end{array}$ & $\begin{array}{l}-.200 \\
(.438)\end{array}$ & $\begin{array}{l}-.453 \\
(.461)\end{array}$ & $\begin{array}{c}-2.692^{* *} \\
(1.254)\end{array}$ & $\begin{array}{l}-.974 \\
(.752)\end{array}$ & $\begin{array}{l}-1.961^{*} \\
(1.044)\end{array}$ \\
\hline Constant & $\begin{array}{l}1.720^{3+x+x} \\
(.610)\end{array}$ & $\begin{array}{c}.353 \\
(.393)\end{array}$ & $\begin{array}{l}.965 \\
(.690)\end{array}$ & $\begin{array}{l}.696^{\star} \\
(.407)\end{array}$ & $\begin{array}{l}6.850^{+* 4 x} \\
(1.057)\end{array}$ & $\begin{array}{l}6.425^{\star * x} \\
(1.322)\end{array}$ & $\begin{array}{l}6.742^{\star \star \star} \\
(1.082)\end{array}$ & $\begin{array}{l}6.534^{*+\alpha} \\
(1.277)\end{array}$ \\
\hline No. of districts & 67 & 67 & 67 & 67 & 67 & 67 & 67 & 67 \\
\hline Observations & 324 & 324 & 324 & 324 & 329 & 329 & 329 & 329 \\
\hline No. of instruments & 17 & 19 & 18 & 18 & 17 & 19 & 18 & 18 \\
\hline Hansen test & .49 & .23 & .28 & .30 & .02 & .01 & .02 & .01 \\
\hline Diff.-in-Hansen test & .23 & .09 & .22 & .22 & .00 & .08 & .00 & .03 \\
\hline Arellano-Bond $\operatorname{ar}(1)$ & .01 & .01 & .01 & .01 & .07 & .21 & .13 & .19 \\
\hline Arellano-Bond ar(2) & .92 & .76 & .84 & .79 & .12 & .39 & .11 & .16 \\
\hline
\end{tabular}


Table E 26: System GMM health per capita expenditure-Hosp_OPDStaffpc

\begin{tabular}{|c|c|c|c|c|c|c|c|c|}
\hline & \multicolumn{4}{|c|}{ with lagged dependent variable as regressor } & \multicolumn{4}{|c|}{ without lagged dependent variable as regressor } \\
\hline & $(1)^{a}$ & $(2)^{b}$ & $(3)^{c}$ & $(4)^{d}$ & $(5)^{a}$ & $(6)^{b}$ & $(7)^{c}$ & $(8)^{d}$ \\
\hline \multirow[t]{2}{*}{ ELF-E } & .032 & .065 & .043 & .057 & .022 & .006 & .002 & .017 \\
\hline & $(.130)$ & $(.105)$ & $(.116)$ & $(.111)$ & $(.264)$ & $(.240)$ & $(.251)$ & $(.249)$ \\
\hline \multirow{2}{*}{$\begin{array}{l}\text { HospOPDStaffpc } \sim \mathrm{t} \\
1\end{array}$} & $.759^{\star \star}$ & $.687^{\star \star}$ & $.714^{\star *}$ & $.724^{* *}$ & & & & \\
\hline & $(.367)$ & $(.283)$ & $(.290)$ & $(.340)$ & & & & \\
\hline Expenditure p.c. & $\begin{array}{l}4.467 \\
(5.075)\end{array}$ & $\begin{array}{l}5.120 \\
(4.303)\end{array}$ & $\begin{array}{r}5.254 \\
(4.263)\end{array}$ & $\begin{array}{c}4.412 \\
(5.042)\end{array}$ & $\begin{array}{l}8.340^{*} \\
(4.353)\end{array}$ & $\begin{array}{l}10.531^{\star *} \\
(4.687)\end{array}$ & $\begin{array}{l}10.263^{\star *} \\
(4.981)\end{array}$ & $\begin{array}{l}8.741^{* *} \\
(4.277)\end{array}$ \\
\hline Rural & $\begin{array}{l}-.032 \\
(.142)\end{array}$ & $\begin{array}{l}-.043 \\
(.127)\end{array}$ & $\begin{array}{l}-.035 \\
(.133)\end{array}$ & $\begin{array}{l}-.040 \\
(.133)\end{array}$ & $\begin{array}{c}-.401^{*+*} \\
(.141)\end{array}$ & $\begin{array}{l}-.378^{* *} \\
(.142)\end{array}$ & $\begin{array}{l}-.383^{*+x} \\
(.142)\end{array}$ & $\begin{array}{l}-.395^{\text {tox }} \\
(.139)\end{array}$ \\
\hline Area $(1000 \mathrm{~km} 2)$ & $\begin{array}{l}-.001 \\
(.003)\end{array}$ & $\begin{array}{l}-.002 \\
(.002)\end{array}$ & $\begin{array}{l}-.001 \\
(.003)\end{array}$ & $\begin{array}{l}-.001 \\
(.003)\end{array}$ & $\begin{array}{l}-.004 \\
(.005)\end{array}$ & $\begin{array}{l}-.003 \\
(.004)\end{array}$ & $\begin{array}{l}-.003 \\
(.005)\end{array}$ & $\begin{array}{l}-.003 \\
(.005)\end{array}$ \\
\hline Poverty & $\begin{array}{l}-.220 \\
(.249)\end{array}$ & $\begin{array}{l}-.235 \\
(.209)\end{array}$ & $\begin{array}{c}-.235 \\
(.211)\end{array}$ & $\begin{array}{c}-.222 \\
(.241)\end{array}$ & $\begin{array}{c}-.799^{*+\alpha} \\
(.294)\end{array}$ & $\begin{array}{l}-.807^{\text {*t }} \\
(.3111)\end{array}$ & $\begin{array}{l}-.817^{* \alpha+x} \\
(.294)\end{array}$ & $\begin{array}{c}-.807^{\text {t*x }} \\
(.285)\end{array}$ \\
\hline 2005 & $\begin{array}{c}.050 \\
(.073)\end{array}$ & $\begin{array}{c}.032 \\
(.063)\end{array}$ & $\begin{array}{l}.037 \\
(.063)\end{array}$ & $\begin{array}{l}.043 \\
(.070)\end{array}$ & $\begin{array}{l}-.032 \\
(.032)\end{array}$ & $\begin{array}{l}-.041 \\
(.031)\end{array}$ & $\begin{array}{l}-.039 \\
(.032)\end{array}$ & $\begin{array}{l}-.033 \\
(.032)\end{array}$ \\
\hline 2006 & $\begin{array}{l}-.065 \\
(.175)\end{array}$ & $\begin{array}{l}-.098 \\
(.149)\end{array}$ & $\begin{array}{l}-.097 \\
(.147)\end{array}$ & $\begin{array}{l}-.070 \\
(.172)\end{array}$ & $\begin{array}{l}-.232^{*} \\
(.118)\end{array}$ & $\begin{array}{l}-.292^{* *} \\
(.120)\end{array}$ & $\begin{array}{l}-.285^{*+} \\
(.131)\end{array}$ & $\begin{array}{l}-.243^{\text {** }} \\
(.115)\end{array}$ \\
\hline 2007 & $\begin{array}{l}-.099 \\
(.188)\end{array}$ & $\begin{array}{l}-.128 \\
(.156)\end{array}$ & $\begin{array}{l}-.133 \\
(.153)\end{array}$ & $\begin{array}{l}-.097 \\
(.187)\end{array}$ & $\begin{array}{l}-.241^{*} \\
(.129)\end{array}$ & $\begin{array}{l}-.300^{*+*} \\
(.130)\end{array}$ & $\begin{array}{l}-.295^{* *} \\
(.146)\end{array}$ & $\begin{array}{l}-.252^{* *} \\
(.120)\end{array}$ \\
\hline 2008 & $\begin{array}{l}-.188 \\
(.306)\end{array}$ & $\begin{array}{l}-.230 \\
(.261)\end{array}$ & $\begin{array}{l}-.235 \\
(.259)\end{array}$ & $\begin{array}{l}-.188 \\
(.302)\end{array}$ & $\begin{array}{l}-.463^{* *} \\
(.222)\end{array}$ & $\begin{array}{l}-.584^{* *} \\
(.232)\end{array}$ & $\begin{array}{l}-.569^{* *} \\
(.257)\end{array}$ & $\begin{array}{l}-.485^{* *} \\
(.215)\end{array}$ \\
\hline Constant & $\begin{array}{l}.258 \\
(.535)\end{array}$ & $\begin{array}{l}.338 \\
(.428)\end{array}$ & $\begin{array}{l}.309 \\
(.441)\end{array}$ & $\begin{array}{l}.296 \\
(.498)\end{array}$ & $\begin{array}{l}1.504^{* \star \star \star} \\
(.303)\end{array}$ & $\begin{array}{c}1.490^{*+*+} \\
(.301)\end{array}$ & $\begin{array}{l}1.500^{* * *} \\
(.296)\end{array}$ & $\begin{array}{c}1.504^{* *+x} \\
(.293)\end{array}$ \\
\hline No. of districts & 52 & 52 & 52 & 52 & 53 & 53 & 53 & 53 \\
\hline Observations & 250 & 250 & 250 & 250 & 255 & 255 & 255 & 255 \\
\hline No. of instruments & 17 & 19 & 18 & 18 & 17 & 19 & 18 & 18 \\
\hline Hansen test & 14 & .25 & .20 & 18 & .30 & .59 & .48 & .42 \\
\hline Diff.-in-Hansen test & .01 & .05 & .05 & .05 & .06 & .37 & .27 & 12 \\
\hline Arellano-Bond $\operatorname{ar}(1)$ & 12 & .10 & .09 & .11 & .04 & .03 & .03 & .04 \\
\hline Arellano-Bond $\operatorname{ar}(2)$ & .12 & .13 & 12 & 12 & .23 & .28 & .28 & .24 \\
\hline $\begin{array}{l}\text { Notes: }^{a}(1) \text { and (5) } \\
\text { internal and external } \\
\text { instrument; }{ }^{d}(4) \text { and }\end{array}$ & $\begin{array}{l}y \text { inte } \\
\text { pulat } \\
\text { inte }\end{array}$ & م & $\begin{array}{l}\text { nd lo } \\
\text { ct car }\end{array}$ & instrt & nent & health & $\begin{array}{l}\text { ure); }{ }^{b} \\
\text { le exte }\end{array}$ & ) use \\
\hline
\end{tabular}


Table E 27: Overview results of system-GMM estimation for ELF-E fractionalization, instrumenting for per capita sector expenditure

with lagged dependent variable as regressor

without lagged dependent variable as regressor

\begin{tabular}{|c|c|c|c|c|c|c|c|c|}
\hline Model & $(1)^{a}$ & $(2)^{b}$ & $(3)^{c}$ & $(4)^{d}$ & $(5)$ & $(6)^{b}$ & $(7)^{c}$ & $(8)^{d}$ \\
\hline \multicolumn{9}{|l|}{ Dependent variable } \\
\hline primary school enrolment & .040 & $.047^{*}$ & .044 & .044 & .207 & .236 & .230 & .212 \\
\hline $\begin{array}{l}\text { lower sec. school } \\
\text { enrolment }\end{array}$ & .017 & .027 & .026 & .019 & .094 & .118 & .113 & .103 \\
\hline tbedspc & $-.832^{*}$ & -.402 & -.491 & -.552 & $-1.667^{\star \star \star}$ & $-1.429^{*}$ & $-1.361^{\star *}$ & $-1.490^{\star \star \star}$ \\
\hline HC_Staffpc & .559 & .075 & .327 & .124 & $2.884^{* *}$ & $2.895^{\star *}$ & $2.932^{* *}$ & $3.123^{\star *}$ \\
\hline Hosp_OPDStaffpc & .032 & .065 & .043 & .057 & .022 & .006 & .002 & .017 \\
\hline BCGimmun & $.162^{*}$ & .129 & .123 & $.149^{*}$ & $.197^{\star \star}$ & .131 & .159 & .157 \\
\hline DPT3immun & $.168^{\star \star}$ & .088 & $.142^{\star *}$ & $.097^{\star}$ & $.266^{\star \star *}$ & $.311^{\star *}$ & $.251^{\star \star}$ & $.311^{\star *}$ \\
\hline OPV3immun & $.233^{\star \star \star}$ & $.142^{\star}$ & $.216^{\star \star}$ & $.150^{*}$ & $.267^{\star \star \star}$ & $.336^{\star \star}$ & $.260^{\star \star}$ & $.330^{\star *}$ \\
\hline Measles & $.170^{\star}$ & .151 & .144 & $.162^{*}$ & $.203^{*}$ & .189 & .166 & .211 \\
\hline FICimmun & $.302^{\star \star \star}$ & $.165^{\star *}$ & $.292^{\star \star \star}$ & $.182^{\star *}$ & $.337^{\star \star \star}$ & $.405^{* \star *}$ & $.338^{\star \star *}$ & $.406^{\star * \star}$ \\
\hline maternalmortality & -53.913 & -2.377 & -42.195 & -20.029 & -69.613 & -39.841 & -62.971 & -49.836 \\
\hline under5mortality & -10.607 & -8.796 & -9.436 & -9.014 & -10.672 & -21.337 & -12.679 & -19.911 \\
\hline underweight5 & 3.201 & .242 & 3.213 & .997 & $-11.299^{\star \star *}$ & $-12.605^{\star \star \star}$ & $-11.928^{\star \star *}$ & $-11.353^{\star \star *}$ \\
\hline \multicolumn{9}{|c|}{$\begin{array}{l}\text { Notes: values show estimated coefficient for ELF-E fractionalization index; }{ }^{a}(1) \text { and }(5) \text { use only internal instruments (second and longer lags o } \\
\text { central government education/health expenditure); }{ }^{b}(2) \text { and }(6) \text { use both internal and external (log population and distance from district capital to } \\
\text { instruments } \\
\text { Lusaka) } \\
{ }^{c}(3) \text { and }(7) \text { use internal and one external (log population) instrument; }{ }^{d}(4) \text { and (8) use internal and one external (distance to Lusaka) instrument. } \\
{ }^{*} p<0.10,{ }^{* \star} p<0.05,{ }^{* \star \star} p<0.01 .\end{array}$} \\
\hline
\end{tabular}


Table E 28: Overview results of system-GMM estimation for language fractionalization instrumenting for total sector expenditure

with lagged dependent variable as regressor

without lagged dependent variable as regressor

\begin{tabular}{|c|c|c|c|c|c|c|c|c|}
\hline Model & $(1)^{a}$ & $(2)^{b}$ & $(3)^{c}$ & $(4)^{d}$ & & $(6)^{b}$ & $(7)^{c}$ & $(8)^{d}$ \\
\hline \multicolumn{9}{|l|}{ Dependent variable } \\
\hline primary school enrolment & .033 & .033 & .036 & .033 & $.262^{*}$ & $.254^{\star}$ & $.255^{*}$ & $.253^{\star}$ \\
\hline $\begin{array}{l}\text { lower sec. school } \\
\text { enrolment }\end{array}$ & -.007 & .005 & .011 & -.009 & -.004 & .007 & .023 & -.038 \\
\hline tbedspc & $-1.054^{*}$ & -.315 & -.388 & $-.790^{*}$ & $-1.377^{\star \star \star}$ & $-1.544^{* *}$ & $-1.523^{* *}$ & $-1.669^{* \star \star}$ \\
\hline HC_Staffpc & .427 & -.115 & .297 & -.110 & 2.471 & 3.132 & 2.876 & 2.847 \\
\hline Hosp_OPDStaffpc & -.052 & -.039 & -.075 & -.059 & -.124 & -.033 & -.016 & -.113 \\
\hline BCGimmun & $.208^{*}$ & .168 & .150 & $.229^{\star \star}$ & $.242^{\star \star}$ & $.203^{*}$ & $.187^{\star}$ & $.271^{\star \star}$ \\
\hline DPT3immun & $.223^{\star}$ & $.121^{*}$ & $.163^{\star *}$ & $.136^{\star}$ & $.398^{\star \star \star}$ & $.337^{\star *}$ & $.293^{\star \star}$ & $.385^{\star \star}$ \\
\hline OPV3immun & $.307^{\star *}$ & $.177^{\star}$ & $.228^{\star \star}$ & $.191^{*}$ & $.384^{\star \star \star}$ & $.343^{\star *}$ & $.279^{\star \star}$ & $.385^{\star \star}$ \\
\hline Measles & $.250^{\star *}$ & $.182^{\star}$ & $.194^{\star}$ & $.218^{\star}$ & $.283^{\star \star}$ & .230 & $.233^{\star}$ & .274 \\
\hline FICimmun & $.334^{\star \star \star}$ & $.196^{\star}$ & $.329^{\star \star \star}$ & $.190^{*}$ & $.387^{\star \star \star}$ & $459^{\star \star \star}$ & $.385^{\star \star \star}$ & $.449^{\star \star \star}$ \\
\hline maternalmortality & 11.952 & 68.639 & 4.803 & 52.058 & -9.975 & 32.047 & -28.037 & 31.051 \\
\hline under5mortality & -9.236 & -9.840 & -10.197 & -11.816 & -18.632 & -16.048 & -14.161 & -22.921 \\
\hline underweight5 & $3.585^{*}$ & 1.453 & $3.566^{*}$ & 1.837 & $-8.901^{\star \star *}$ & $-10.360^{\star *}$ & $-9.079^{\star \star \star}$ & $-9.499^{\star *}$ \\
\hline
\end{tabular}

Notes: values show estimated coefficient for language fractionalization index ELF-L; ${ }^{a}$ (1) and (5) use only internal instruments (second and longer lags of central government education/health expenditure); ${ }^{b}(2)$ and (6) use both internal and external (log population and distance from district capital
to Lusaka) instruments;

${ }^{c}(3)$ and (7) use internal and one external (log population) instrument; ${ }^{d}$ (4) and (8) use internal and one external (distance to Lusaka) instrument;

${ }^{*} p<0.10,{ }^{* \star} p<0.05,{ }^{* \star *} p<0.01$. 